Florida International University FIU Digital Commons

$4-5-2005$

\title{
Relative basicities of free base porphyrins : understanding the role of macrocyclic distortion
}

Maria Ballester

Florida International University

DOI: $10.25148 /$ etd.FI14050420

Follow this and additional works at: https://digitalcommons.fiu.edu/etd

Part of the Chemistry Commons

\section{Recommended Citation}

Ballester, Maria, "Relative basicities of free base porphyrins : understanding the role of macrocyclic distortion" (2005). FIU Electronic Theses and Dissertations. 1383.

https://digitalcommons.fiu.edu/etd/1383

This work is brought to you for free and open access by the University Graduate School at FIU Digital Commons. It has been accepted for inclusion in FIU Electronic Theses and Dissertations by an authorized administrator of FIU Digital Commons. For more information, please contact dcc@fiu.edu. 
FLORIDA INTERNATIONAL UNIVERSITY

Miami, Florida

RELATIVE BASICITIES OF FREE BASE PORPHYRINS; UNDERSTANDING THE ROLE OF MACROCYCLIC DISTORTION

A dissertation submitted in partial fulfillment of the requirements for the degree of DOCTOR OF PHILOSOPHY

in

CHEMISTRY

by

Maria Ballester

2005 
To: Interim Dean Mark Szuchman

College of Arts and Sciences

This dissertation, written by Maria Ballester, and entitled Relative Basicities of Free Base Porphyrins; Understanding the Role of Macrocyclic Distortion, having been approved in respect to style and intellectual content, is referred to you for judgment.

We have read this dissertation and recommend that it ibe approved.

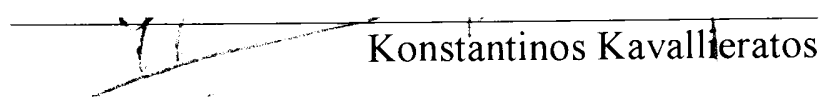

Richard Bone

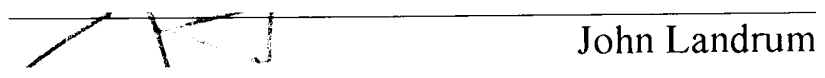

$i$

David Chatfield

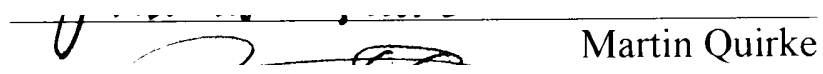

Ramon Lopezde la Vega, Major Professor

Date of Defense: April 5, 2005

The dissertation of Maria Ballester is approved.

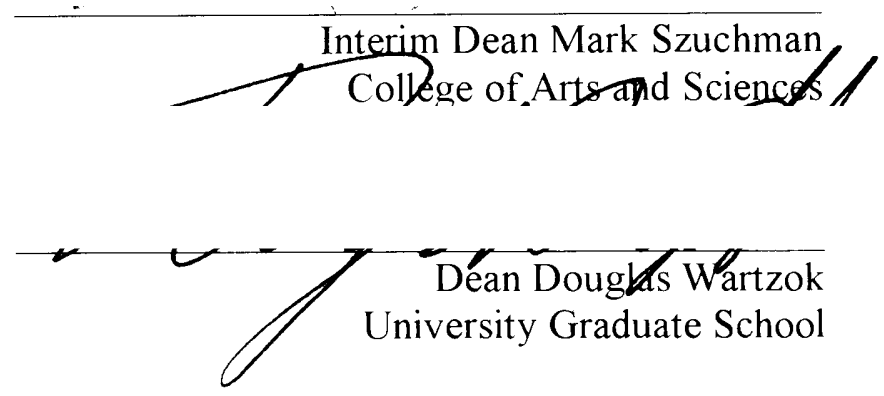

Florida International University, 2005 


\section{DEDICATION}

I dedicate this dissertation to my daughter Angelica Pilar Tracey who was not only born during this degree but have also helped me get through this work by her always growing love and happiness. To my husband Martin Tracey for being the support behind everything I do. And to my mother who always have been there to encourage and support me in my education. 


\section{ACKNOWLEDGMENTS}

I would like to express my gratitude to Dr. Ramon Lopez de la Vega for his support and guidance. Several professors have definitely contributed more assistance than duty dictated and my thanks cannot adequately express my appreciation. To Dr. Martin Quirke for all the time spent helping me and guiding me, and to Dr. David Chatfield for all the time spent teaching me a new area of Chemistry, I extend my deepest thanks. 


\section{ABSTRACT OF THE DISSERTATION \\ RELATIVE BASICITIES OF FREE BASE PORPHYRINS; UNDERSTANDING THE ROLE OF MACROCYCLIC DISTORTION}

by

Maria Ballester

Florida International University, 2005

Miami, Florida

Professor Ramon Lopez de la Vega, Major Professor

Porphyrins have been the center of numerous investigations in different areas of chemistry, geochemistry, and the life sciences. In nature the conformation of the porphyrin macrocycle varies, depending on the function of its apoenzyme. It is believed that the conformation of the porphyrin ring is necessary for the enzyme to achieve its function and modify its reactivity. It is important to understand how the conformation of the porphyrin ring will influence its properties.

In synthetic porphyrins particular conformations and ring deformations can be achieved by peripheral substitution, metallation, core substitution, and core protonation among other alterations of the macrocycle. The macrocyclic distortions will affect the ring current, the ability of pyrroles to intramolecularly hydrogen bond and the relative basicity of each of the porphyrins. To understand these effects different theoretical models are used. The ground state structure of each of 19 free base porphyrins is determined using molecular mechanics $(\mathrm{MM}+$ ) and semiempirical methods (PM3). The energetics of deformation of the macrocyclic core is calculated by carrying out single point energy calculations for the conformation achieved by each synthetic compound. 
Enthalpies of solution and enthalpies of protonation of 10 porphyrins with varying degrees of macrocyclic deformation and varying electron withdrawing groups in the periphery are determined using solution calorimetry. Using Hess's Law, the relative basicity of each of the different free base porphyrins is calculated. NMR results are described, including the determination of free energies of activation of ring tautomerization and hydrogen bonding for several compounds. It was found that in the absence of electronic effects, the greater macrocyclic deformation, the greater the basicity of the porphyrins. This basicity is attenuated by the presence of electron withdrawing groups and ability to of the macrocycle to intramolecularly hydrogen bond. 


\section{TABLE OF CONTENTS}

CHAPTER

PAGE

1. Introduction

1.1. The porphyrin structure

1.2. Basic formats for porphyrin nomenclature

1.2.1. Fischer

1.2.2. IUPAC Nomenclature

1.3. Importance of porphyrins and related compounds 11

1.4. Importance of porphyrins in biological chemistry and biology $\quad 12$

1.5. Porphyrins and related compounds in medicine 13

1.6. Porphyrins and Inorganic Chemistry 13

$\begin{array}{ll}\text { 1.7. Porphyrins and Geology } & 14\end{array}$

1.8. Porphyrin synthesis and synthetic porphyrins 15

1.8.1. Syntheses of symmetrical octaalkylporphyrins without meso substituents

1.8.2. Syntheses of meso tetrasubstituted porphyrins without $\beta$-pyrrole substituents

1.8.3. Syntheses of dodecasubstituted porphyrins 18

1.8.3.1.Syntheses of dodecaalkylporphyrins $\quad 18$

1.8.3.2. Syntheses of dodeca(alkyl/aryl)porphyrins 18

$\begin{array}{ll}\text { 1.9. Spectroscopic properties of porphyrins } & 19\end{array}$

1.9.1. UV-Vis Spectroscopy 19

1.9.2. ${ }^{1}$ H NMR Spectroscopy 21

$1.10 \mathrm{NH}$ Tautomerism in porphyrin systems 22

1.11 Calorimetry studies $\quad 24$

2. Conformations in porphyrins 25

2.1 Relevance to biological systems 25

2.2 Variations in porphyrin conformation 26

2.3 X-ray crystal studies $\quad 29$

3. Molecular modeling in porphyrin systems $\quad 30$

3.1 Molecular mechanics or force field method 31

3.2 The semiempirical molecular orbital method 31

3.3 Density functional theory 31

4. Statement of the problem 33

5. Experimental 34

5.1. Free base porphyrins $\quad 34$

5.2. Thermodynamic studies $\quad 39$

5.3. Competition studies 40

5.4. NMR studies $\quad 40$ 
6. Results and discussion $\quad 44$

6.1. Calorimetric studies $\quad 44$

6.1.1. Enthalpies of solution 46

6.1.2. Energetics of two proton transfer 47

6.1.3. Competition studies $\quad 50$

6.2. Molecular modeling studies 53

6.2.1. Free-base porphyrins $\mathrm{MM}+$ and $\mathrm{PM} 3$ calculations 53

6.2.2. Validity of the optimized structures 75

6.2.3. Dications MM+ and PM3 calculations $\quad 80$

6.2.4. Core energetics 81

6.2.5. Free base porphyrins $\mathrm{PM} 3 / / \mathrm{MM}^{+}$ and B3LYP/6-31G*//MM+ calculations 86

6.2.6. Energetics of core deformation and relative basicity 91

6.3. Nuclear magnetic resonance studies 95

$\begin{array}{ll}\text { 7. Conclusions } & 109\end{array}$

7.1. Calorimetry 109

7.2. Molecular modeling $\quad 110$

$\begin{array}{ll}\text { 7.3. }{ }^{1} \mathrm{H} \text { NMR } & 110\end{array}$

$\begin{array}{ll}\text { References } & 111\end{array}$

$\begin{array}{ll}\text { Vita } & 118\end{array}$ 


\section{LIST OF TABLES}

TABLE

PAGE

1. Terms and abbreviations 1

2. Enthalpies of solution and protonation in solution of different synthetic symmetrical porphyrins in 1, 1, 2, 2-tetrachloroethane (TCE)

3. Enthalpy of two proton transfer, macrocyclic conformation and Hammett's $\sigma$ parameter for $R_{1}$ and substituents

4. Bond lengths, angles and distances obtained from the MM+ optimized structure of $\mathrm{H}_{2} \mathrm{OEP}(5)$

5. Bond lengths, angles and distances obtained from the $\mathrm{MM}+$ optimized structure of $\mathrm{H}_{2} \mathrm{ETIO} 1$ (6)

6. Bond lengths, angles and distances obtained from the $\mathrm{MM}+$ optimized structure of $\mathrm{H}_{2} \mathrm{O}(\mathrm{iPr}) \mathrm{P}(7)$

7. Bond lengths, angles and distances obtained from the $\mathrm{MM}+$ optimized structure of $\mathrm{H}_{2} \mathrm{TPP}(8)$

8. Bond lengths, angles and distances obtained from the $\mathrm{MM}+$ optimized structure of $\mathrm{H}_{2} \mathrm{~T}(\mathrm{nPe}) \mathrm{P}(9)$

9. Bond lengths, angles and distances obtained from the MM+ optimized structure of $\mathrm{H}_{2} \mathrm{~T}(\mathrm{iPr}) \mathrm{P}(10)$

10. Bond lengths, angles and distances obtained from the $\mathrm{MM}+$ optimized structure of $\mathrm{H}_{2} \mathrm{~T}(\mathrm{tBu}) \mathrm{P}(11)$

11. Bond lengths, angles and distances obtained from the $\mathrm{MM}+$ optimized structure of $\mathrm{H}_{2} \mathrm{~T}\left(\mathrm{nC}_{5} \mathrm{~F}_{5}\right) \mathrm{P}(12)$

12. Bond lengths, angles and distances obtained from the MM+ optimized structure of $\mathrm{H}_{2} \mathrm{OETPP}$ (13)

13. Bond lengths, angles and distances obtained from the $\mathrm{MM}+$ optimized structure of $\mathrm{H}_{2} 5-\mathrm{NO}_{2} \mathrm{OEP}$ (14)

14. Bond lengths, angles and distances obtained from the $\mathrm{MM}+$ optimized structure of $\mathrm{H}_{2} 5,10$-diNO ${ }_{2} \mathrm{OEP}$ (15) 
15. Bond lengths, angles and distances obtained from the $\mathrm{MM}+$ optimized structure of $\mathrm{H}_{2} 5$, 15-diNO 2 OEP (16)

16. Bond lengths, angles and distances obtained from the MM+ optimized structure of $\mathrm{H}_{2} 5,10,15$-triNO $\mathrm{N}_{2} \mathrm{OEP}$ (17)

17. Bond lengths, angles and distances obtained from the $\mathrm{MM}+$ optimized structure of $\mathrm{H}_{2} 5,10,15,20$-tetraNO${ }_{2} \mathrm{OEP}$ (18)

18. Bond lengths, angles and distances obtained from the $\mathrm{MM}+$ optimized structure of $\mathrm{H}_{2} 5-\mathrm{NO}_{2}$ ETIO1 (19)

19. Bond lengths, angles and distances obtained from the $\mathrm{MM}+$ optimized structure of $\mathrm{H}_{2} 5,10$-diNO $\mathrm{O}_{2}$ ETIO1 (20)

20. Bond lengths, angles and distances obtained from the MM+optimized structure of $\mathrm{H}_{2} 5,15$-diNO ${ }_{2}$ ETIO1 (21)

21. Bond lengths, angles and distances obtained from the $\mathrm{MM}+$ optimized structure of $\mathrm{H}_{2} 5,10,15$-triNO ${ }_{2}$ ETIO1 (22)

22. Bond lengths, angles and distances obtained from the $\mathrm{MM}+$ optimized structure of $\mathrm{H}_{2} 5,10,15,20$-tetraNO $\mathrm{N}_{2}$ ETIOl (23)

23. Parameters associated to non planar distortions obtained through molecular mechanics calculations

24. Comparison of $\mathrm{MM}+$ and $\mathrm{X}$-ray crystal structure of $\mathrm{H}_{2} \mathrm{TPP}(8)$ and $\mathrm{H}_{2} \mathrm{OEP}(5)$

25. Summary of structural parameters generated using molecular mechanics optimization

26. Energies calculated using different models for each free-base porphyrin, the macrocyclic portion and relative to the $\mathrm{H}_{2} \mathrm{OEP}$ conformation

27. Energies calculated using different models for each free-base porphyrin, the macrocyclic portion and relative to the $\mathrm{H}_{2} \mathrm{OEP}$ conformation. Nitrated series of $\mathrm{H}_{2} \mathrm{OEP}(5)$

28. Energies calculated using different models for each free-base porphyrin, the macrocyclic portion and relative to the $\mathrm{H}_{2} \mathrm{OEP}$ conformation. Nitrated series of $\mathrm{H}_{2} \mathrm{OEP}(5)$ 
29. ${ }^{1} \mathrm{H}$ NMR peak positions in ppm for free-base porphyrins

30. $\Delta \mathrm{G}^{*}$ for the tautomerization of different free-base porphyrins 


\section{LIST OF FIGURES}

FIGURE

PAGE

1. (a) Porphyrin skeleton. (b) $18 \pi$-electron system and tautomerization 2

2. Nomenclature system. (a) Fischer system and (b) IUPAC system

3. $\mathrm{H}_{2} \mathrm{OEP}$ synthesis

4. Two-step one-flask room-temperature synthesis of meso-substituted porphyrins. Note that four structural isomers of the porphyrinogen are expected (not shown)

5. $\mathrm{H}_{2} \mathrm{OEP}$ spectrum in $\mathrm{CH}_{2} \mathrm{Cl}_{2}$

6. $\mathrm{H}_{4} \mathrm{OEP}^{2+}$ spectrum in $\mathrm{TFA} / \mathrm{CH}_{2} \mathrm{Cl}_{2}$

7. Tautomerization

8. Non planar distortions in porphyrins 28

9. Theoretical calculations flowchart 42

10. UV-Vis spectra of $\mathrm{H}_{2} \mathrm{OEP}, \mathrm{H}_{3} \mathrm{OEP}{ }^{1+}$, and $\mathrm{H}_{4} \mathrm{OEP}{ }^{2+}$

11. Competition studies of $\mathrm{H}_{2} 5,10,15,20-\mathrm{NO}_{2} \mathrm{OEP}(18)$ and $\mathrm{H}_{2} \mathrm{TPP}(8)$

12. Competition studies of $\mathrm{H}_{2} \mathrm{OEP}(5)$ and $\mathrm{H}_{2}$ TPP (8) 52

13. Competition studies of $\mathrm{H}_{2} \mathrm{OIP}(7)$ and $\mathrm{H}_{2}$ TPP (8) 53

14. Optimized structures of $\mathrm{H}_{2} \mathrm{OEP}$ (5) using $\mathrm{MM}+(\mathrm{a})$ and PM3 (b) calculations. Peripheral substituents have been replaced by hydrogens

15. Optimized structures of $\mathrm{H}_{2}$ ETIO1 (6) using MM+ (a) and PM3 (b) calculations. Peripheral substituents have been replaced by hydrogens

16. Optimized structures of $\mathrm{H}_{2} \mathrm{O}(\mathrm{iPr}) \mathrm{P}$ (7) using $\mathrm{MM}+(\mathrm{a})$ and PM3 (b) calculations. Peripheral substituents have been replaced by hydrogens 
17. Optimized structures of $\mathrm{H}_{2} \mathrm{TPP}(8)$ using $\mathrm{MM}+$ (a) and PM3 (b) calculations. Peripheral substituents have been replaced by hydrogens

18. Optimized structures of $\mathrm{H}_{2} \mathrm{~T}(\mathrm{nPe}) \mathrm{P}$ (9) using $\mathrm{MM}+(\mathrm{a})$ and PM3 (b) calculations. Peripheral substituents have been replaced by hydrogens

19. Optimized structures of $\mathrm{H}_{2} \mathrm{~T}(\mathrm{iPr}) \mathrm{P}$ (10) using $\mathrm{MM}+$ (a) and PM3 (b) calculations. Peripheral substituents have been replaced by hydrogens

20. Optimized structures of $\mathrm{H}_{2} \mathrm{~T}(\mathrm{tBu}) \mathrm{P}$ (11) using $\mathrm{MM}+$ (a) and PM3 (b) calculations. Peripheral substituents have been replaced by hydrogens

21. Optimized structures of $\mathrm{H}_{2} \mathrm{~T}\left(\mathrm{nC}_{5} \mathrm{~F}_{5}\right) \mathrm{P}$ (12) using $\mathrm{MM}+$ (a) and PM3 (b) calculations. Peripheral substituents have been replaced by hydrogens

22. Optimized structures of $\mathrm{H}_{2}$ OETPP (13) using $\mathrm{MM}+$ (a) and PM3 (b) calculations. Peripheral substituents have been replaced by hydrogens

23. Optimized structures of $\mathrm{H}_{2} 5-\mathrm{NO}_{2} \mathrm{OEP}$ (14) using $\mathrm{MM}+$ (a) and PM3 (b) calculations. Peripheral substituents have been replaced by hydrogens

24. Optimized structures of $\mathrm{H}_{2} 5,10$-diNO $\mathrm{N}_{2} \mathrm{OEP}$ (15) using $\mathrm{MM}+$ (a) and PM3 (b) calculations. Peripheral substituents have been replaced by hydrogens

25. Optimized structures of $\mathrm{H}_{2} 5,15$-diNO ${ }_{2} \mathrm{OEP}$ (16) using $\mathrm{MM}+$ (a) and PM3 (b) calculations. Peripheral substituents have been replaced by hydrogens

26. Optimized structures of $\mathrm{H}_{2} 5,10,15$-triNO $\mathrm{O}_{2} \mathrm{OEP}$ (17) using $\mathrm{MM}+$ (a) and PM3 (b) calculations. Peripheral substituents have been replaced by hydrogens

27. Optimized structures of $\mathrm{H}_{2} 5,10,15,20$-tetra $\mathrm{NO}_{2} \mathrm{OEP}$ (18) using $\mathrm{MM}+$ (a) and PM3 (b) calculations. Peripheral substituents have been replaced by hydrogens 
28. Optimized structures of $\mathrm{H}_{2} 5-\mathrm{NO}_{2}$ ETIOl (19) using $\mathrm{MM}+$ (a) and PM3 (b) calculations. Peripheral substituents have been replaced by hydrogens

29. Optimized structures of $\mathrm{H}_{2} 5,10-\mathrm{diNO}_{2}$ ETIOl (20) using $\mathrm{MM}+$ (a) and PM3 (b) calculations. Peripheral substituents have been replaced by hydrogens

30. Optimized structures of $\mathrm{H}_{2} 5,15-\mathrm{diNO}_{2}$ ETIOl (21) using MM+ (a) and PM3 (b) calculations. Peripheral substituents have been replaced by hydrogens

31. Optimized structures of $\mathrm{H}_{2} 5,10,15-$ triNO$_{2}$ ETIOl (22) using MM+ (a) and PM3 (b) calculations. Peripheral substituents have been replaced by hydrogens

32. Optimized structures of $\mathrm{H}_{2} 5,10,15,20$-tetraNO${ }_{2} \mathrm{ETIO} 1$ (23) using $\mathrm{MM}+$ (a) and PM3 (b) calculations. Peripheral substituents have been replaced by hydrogens

33. X-ray crystal structure of $\mathrm{H}_{2} \mathrm{OEP}$ (a) and final optimized structure of $\mathrm{H}_{2} \mathrm{OEP}$ obtained using molecular mechanics calculations (b)

34. Porphyrin dications energy minimized structures obtained from $\mathrm{MM}+(\mathrm{a})$ and $\mathrm{PM} 3$ (b) calculations. $\mathrm{H}_{4} \mathrm{OEP}^{2+}(5), \mathrm{H}_{4} \mathrm{ETIOl}^{2+}$ (6), $\mathrm{H}_{4} \mathrm{O}(\mathrm{iPr}) \mathrm{P}^{2+}$ (7) and $\mathrm{H}_{4} \mathrm{OETPP}^{2+}$ (13)

35. Porphyrin dications energy minimized structures obtained from $\mathrm{MM}+$ (a) and PM3 (b) calculations. $\mathrm{H}_{4} \mathrm{TPP}^{2+}(8), \mathrm{H}_{4} \mathrm{~T}(\mathrm{nPe}) \mathrm{P}^{2+}(9), \mathrm{H}_{4} \mathrm{~T}(\mathrm{iPr}) \mathrm{P}^{2+}(10)$, $\mathrm{H}_{4} \mathrm{~T}(\mathrm{tBu}) \mathrm{P}^{2+}(11)$ and $\mathrm{H}_{4} \mathrm{~T}\left(\mathrm{nC}_{5} \mathrm{~F}_{5}\right) \mathrm{P}^{2+}(12)$

36. Porphyrin dications energy minimized structures obtained from $\mathrm{MM}+$ (a) and PM3 (b) calculations. $\mathrm{H}_{2} 5-\mathrm{NO}_{2} \mathrm{OEP}(14), \mathrm{H}_{2} 5,15-\mathrm{NO}_{2} \mathrm{OEP}(15)$, $\mathrm{H}_{2} 5,10-\mathrm{NO}_{2} \mathrm{OEP}(16), \mathrm{H}_{2} 5,10,15-\mathrm{NO}_{2} \mathrm{OEP}(17)$ and $\mathrm{H}_{2} 5,10,15,20-\mathrm{NO}_{2} \mathrm{OEP}(18)$

37. Porphyrin dications energy minimized structures obtained from $\mathrm{MM}+$ (a) and PM3 (b) calculations. $\mathrm{H}_{2} 5-\mathrm{NO}_{2}$ ETIOl (19), $\mathrm{H}_{2} 5,15-\mathrm{NO}_{2}$ ETIO1 (20), $\mathrm{H}_{2} 5,10-\mathrm{NO}_{2}$ ETIO1 (21), $\mathrm{H}_{2} 5,10,15-\mathrm{NO}_{2}$ ETIO1 (22) and $\mathrm{H}_{2} 5,10,15,20-\mathrm{NO}_{2}$ ETIO1 (23)

38. ${ }^{1} \mathrm{H}$ NMR spectra of $\mathrm{H}_{2} \mathrm{OEP}(5), \mathrm{H}_{2} \mathrm{TPP}(8)$ and $\mathrm{H}_{2} \mathrm{~T}(\mathrm{iPr}) \mathrm{P}(10)$ 
40. Variable temperature spectra of $\mathrm{H}_{2} 5,10,15,20$-tetraNO $2 \mathrm{OEP}$ (18), (a) $-\mathrm{CH}_{3}$ region and (b) $-\mathrm{CH}_{2}$ - region

41. Variable temperature spectra of $\mathrm{H}_{2} 5,10,15-\mathrm{triNO}_{2} \mathrm{OEP}$ (17),

(a) $-\mathrm{CH}_{2}$ - region and (b) $-\mathrm{NH}$ region

42. Variable temperature spectra of $\mathrm{H}_{2} 5-\mathrm{NO}_{2} \mathrm{ETIO}$ (19), $-\mathrm{NH}$ region

43. Variable temperature spectra of $\mathrm{H}_{2} 5-\mathrm{NO}_{2} \mathrm{OEP}(14)$, - $\mathrm{NH}$ region 


\section{LIST OF GRAPHS}

GRAPH

PAGE

1. Energy of deformation calculated using four different methods. Only symmetrically substituted porphyrins shown

2. Energy of deformation calculated using three different methods. Nitrated products of $\mathrm{H}_{2}$ ETIOl (6)

3. Energy of deformation calculated using three different methods. Nitrated products of $\mathrm{H}_{2} \mathrm{OEP}$ (5)

4. Enthalpy of proton transfer versus energy of macrocyclic distortion $(\mathrm{MM}+)$

5. Enthalpy of proton transfer versus energy of macrocyclic distortion (PM3)

6. Enthalpy of proton transfer versus energy of macrocyclic distortion (PM3//MM + )

7. Enthalpy of proton transfer versus energy of macrocyclic distortion (B3LYP//MM+) 


\section{Introduction}

\subsection{The porphyrin structure.}

The porphyrin macrocycle is composed of 4 pyrrolic subunits linked via 4 carbon bridges in a cyclic configuration (Figure 1). It is a $22 \pi$-electron system which is fully conjugated. The $\pi$ - system is composed of 2 overlapping $18 \pi$ - electron ring paths and is therefore defined as a $18 \pi$ - electron aromatic system as shown in Figure 1a.[1] In addition to their highly delocalized aromatic nature, porphyrins also undergo tautomerization in the core (Figure 1a). During tautomerization the NH hydrogens are transferred intra-molecularly from the protonated pyrroles to the formerly unprotonated pyrroles.[1]

\subsection{Basic formats for porphyrin nomenclature}

\subsubsection{Fischer}

In the Fischer format, only carbons atoms that can bear substituents are numbered. The format is as follows:

1. Bridge carbons also called meso carbons (see Table 1) are labeled $\alpha, \beta, \gamma, \delta$ as shown in Figure 2a.

2. Carbons that can bear substituents on the pyrrolic rings ( $\beta$ - positions or $\beta$ - pyrrolic positions) are numbered $1,2,3,4,5,6,7$ and 8 as shown in Figure $2 \mathrm{a}$

\subsubsection{IUPAC Nomenclature.}

The carbons are numbered in sequence from 1 to 20 with the meso positions being 5 , $10,15,20$, and the $\beta$-positions being $2,3,7,8,12,13,17$ and 18 . The pyrrolic nitrogens are numbered 21, 22, 23 and 24 (see Figure 2b). 
Standard porphyrin chemistry has a variety of technical terms that are unique to the discipline. For this reason a glossary of such terms is listed in Table 1.

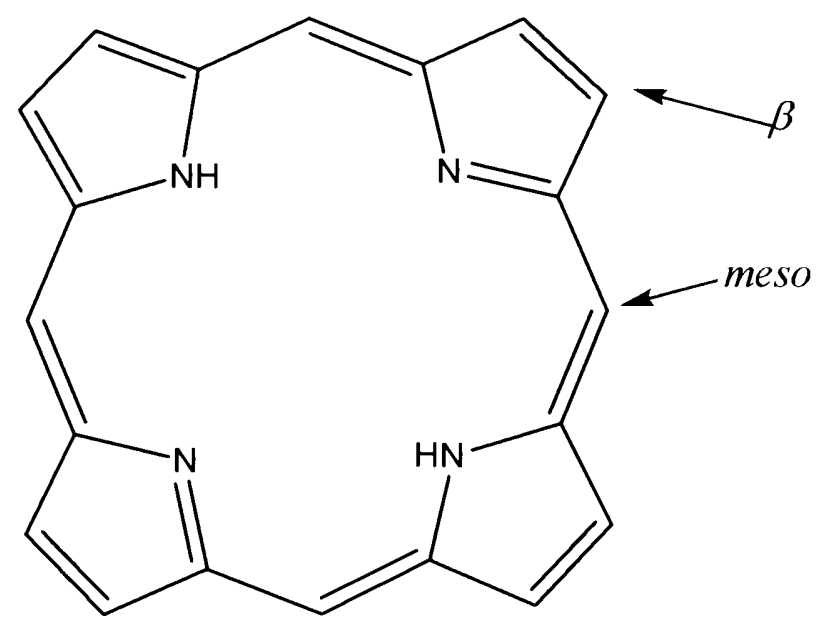

(a)
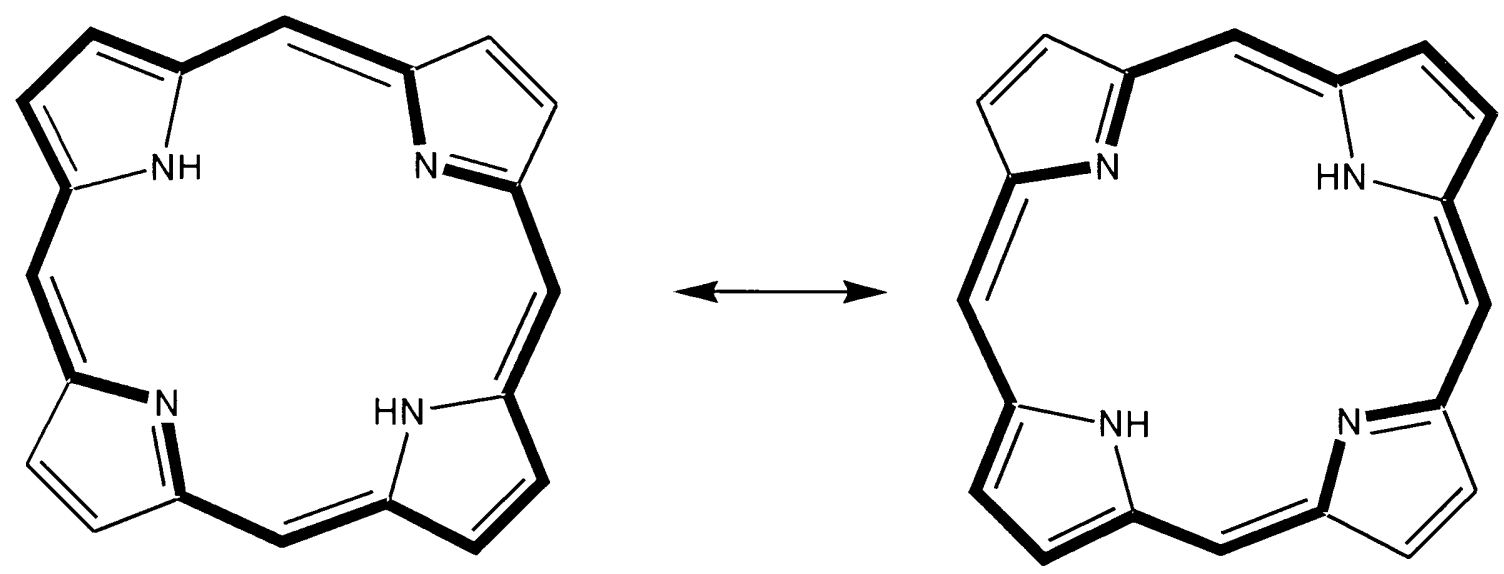

(b)

Figure 1. (a) Porphyrin skeleton and (b) $18 \pi$ electron system and tautomerization. 


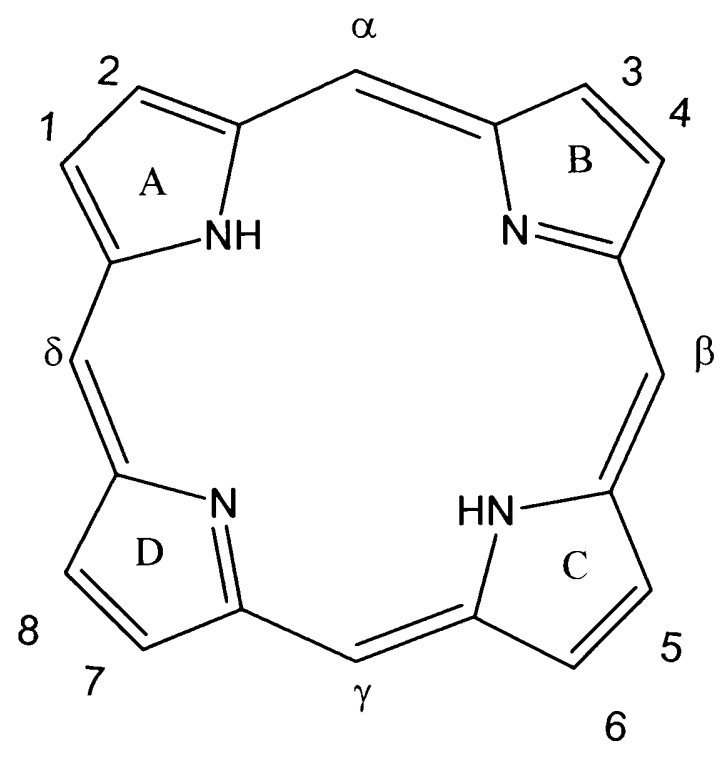

(a) Fischer system

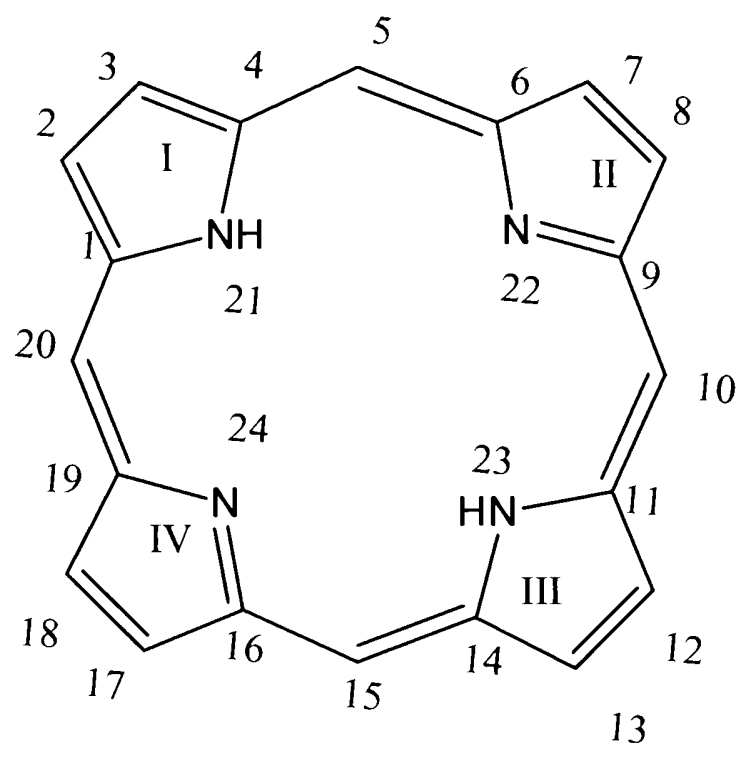

(b) IUPAC system

Figure 2. Numbering system (a) Fischer system, and (b) IUPAC system. 
Table 1. Terms and abbreviations.

\section{Terms or Formula}

Elucidation or Name

\section{Structure}

Cyclic tetrapyrrole (1)

A macrocycle bearing 4 pyrrolic subunits, typically (but not always) formed by 4 carbon bridges.

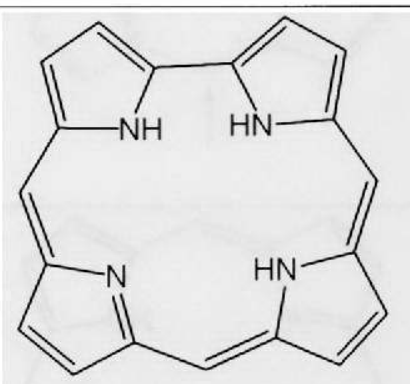

Example: Corrole

Chlorin or Dihydroporphyrin (2)

A porphyrin in which one $\pi$ bond is reduced.

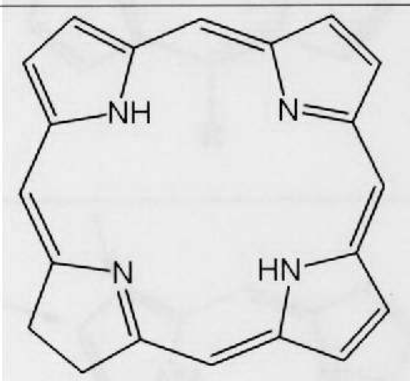

Bacteriochlorin or Tetrahydroporphyrin (3)

A porphyrin in which two $\pi$ bonds are reduced, on each diagonally opposite pyrrolic rings

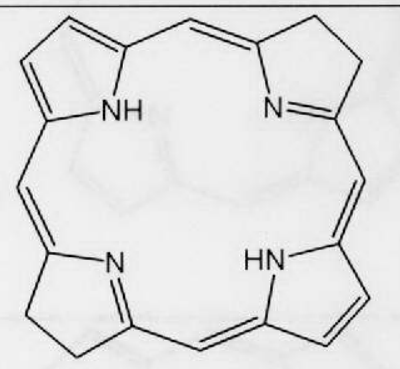

Isobacteriochlorin also a Tetrahydroporphyrin (4)

A porphyrin in which $2 \pi$ bonds are reduced on adjacent pyrrolic rings.

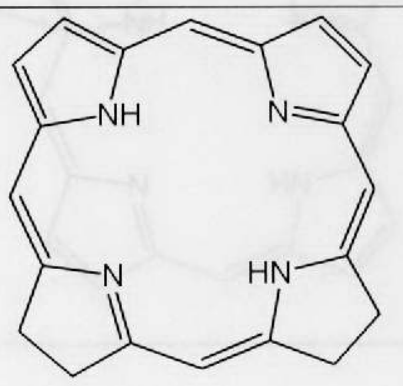


Meso carbon

A carbon bridge

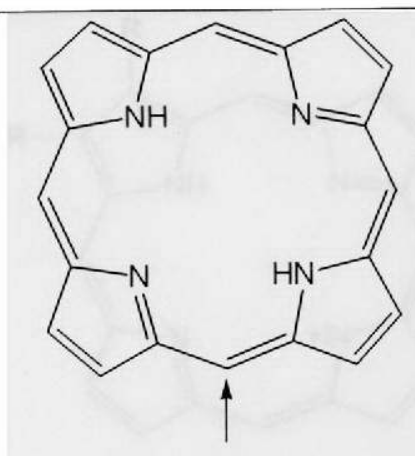

Meso substituents

A substituent on the carbon bridge.

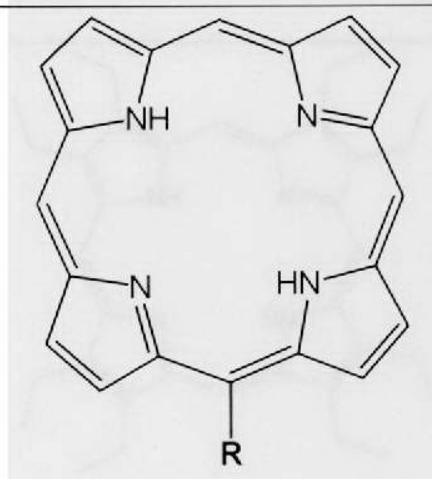

$\beta$-carbon

A carbon on the $\beta$ pyrrolic position.

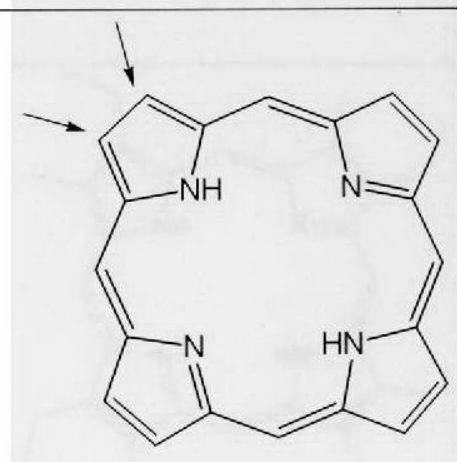

$\alpha$-carbon

The $\alpha$-carbons adjacent to the nitrogens of the pyrrolic rings.

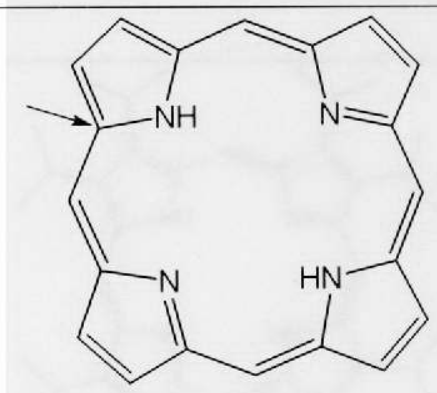


$\beta$-substituent

The substituents on the $\beta$-pyrrolic carbons.

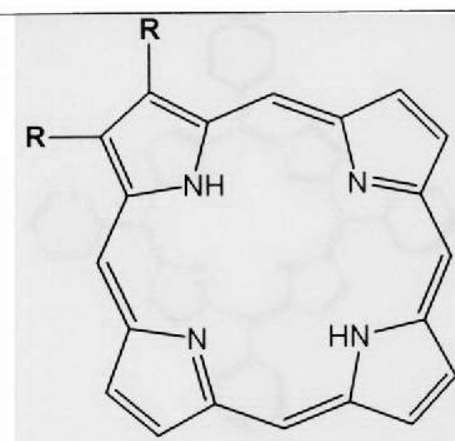

$\mathrm{H}_{2} \mathrm{OEP}$

(5)

Octaethylporphyrin

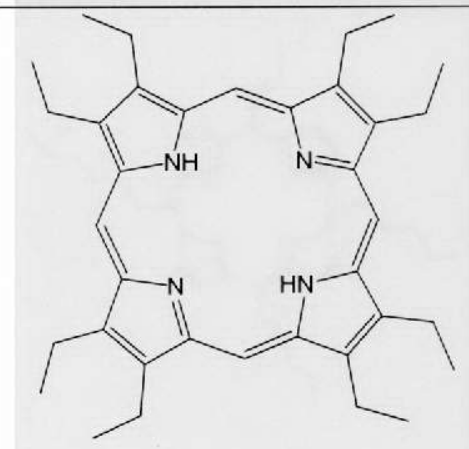

$\mathrm{H}_{2}$ ETIOI

(6)

Etioporphyrin I

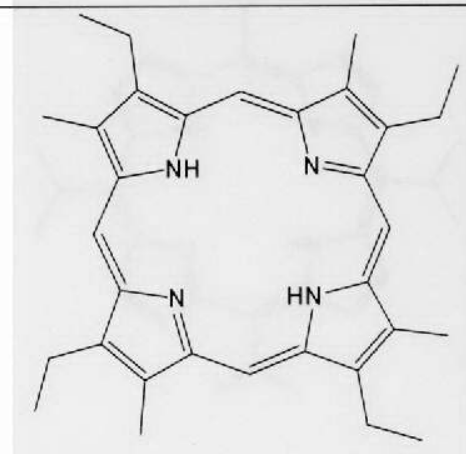

$\mathrm{H}_{2} \mathrm{OIP}$

(7)

Octaisopropylporphyrin

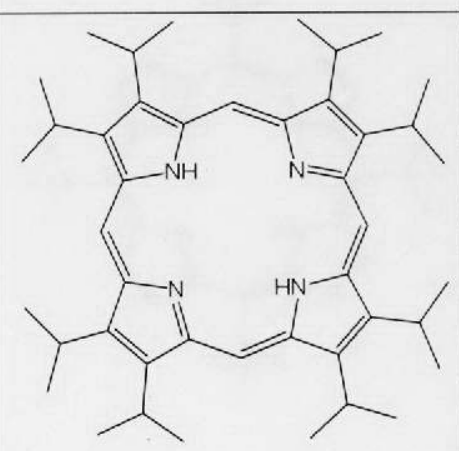


$\mathrm{H}_{2} \mathrm{TPP}$

(8)

Tetraphenylporphyrin

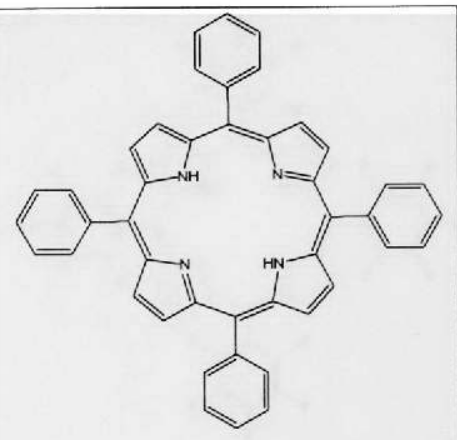

$\mathrm{H}_{2} \mathrm{~T}(\mathrm{nPe}) \mathrm{P}$

Tetra-[2]-pentylporphyrin

$\mathrm{H}_{2} \mathrm{~T}(\mathrm{iPr}) \mathrm{P} \quad$ (10)

Tetraisopropylporphyrin

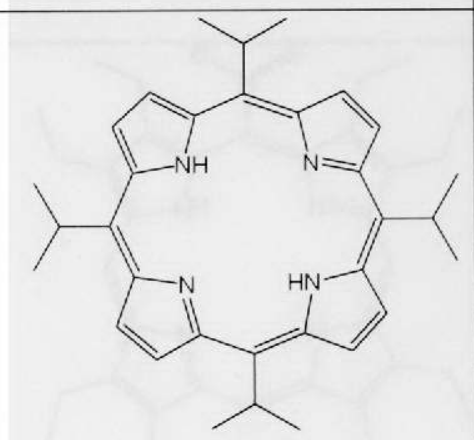

$\mathrm{H}_{2} \mathrm{~T}(\mathrm{tBu}) \mathrm{P}$

Tetratertbutylporphyrin

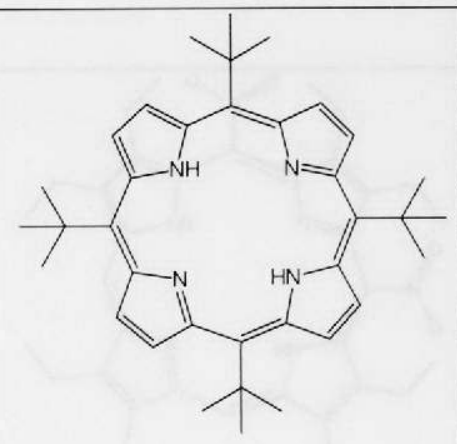


$\mathrm{H}_{2} \mathrm{~T}\left(\mathrm{C}_{6} \mathrm{~F}_{5}\right) \mathrm{P}(\mathbf{1 2})$

Tetrapentafluorophenylporphyrin

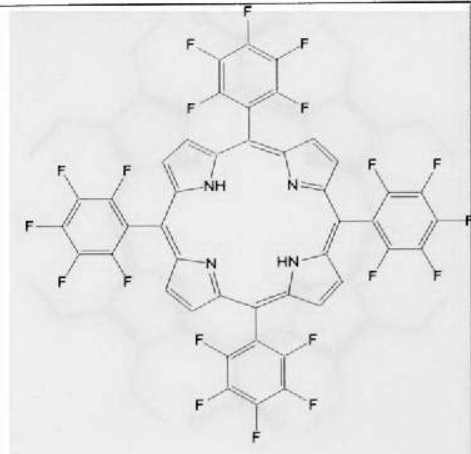

$\mathrm{H}_{2} \mathrm{OETPP}$

(13)

Octaethyltetraphenylporphyrin

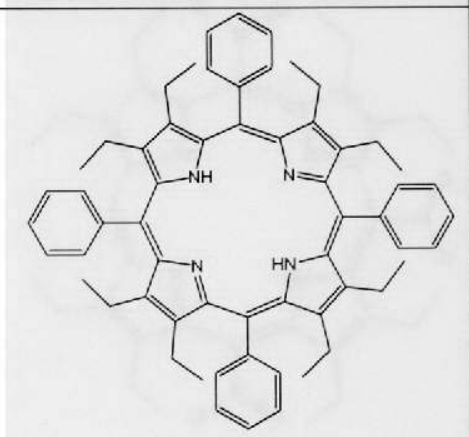

$\mathrm{H}_{2} 5-\mathrm{NO}_{2} \mathrm{OEP} \quad$ (14)

5-nitrooctaethylporphyrin

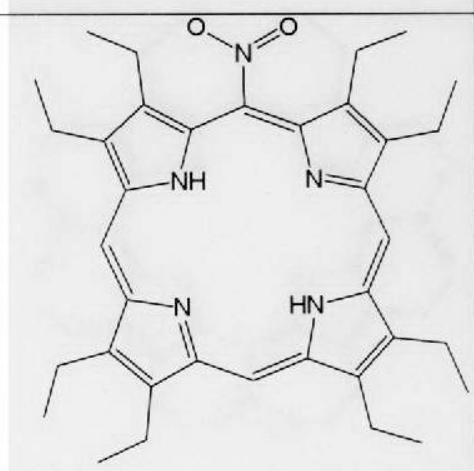

$\mathrm{H}_{2}$ 5,15-diNO ${ }_{2} \mathrm{OEP}$ (15)

5,10-dinitrooctaethylporphyrin

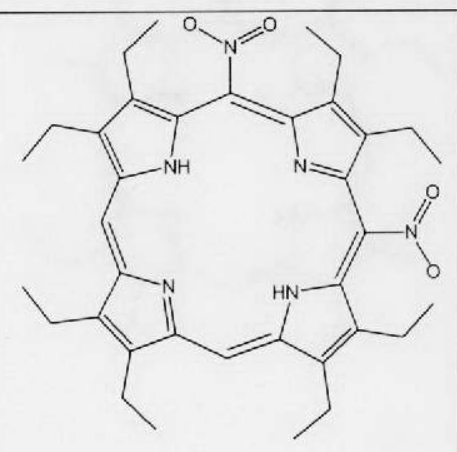


$\mathrm{H}_{2} 5,10-\mathrm{diNO}_{2} \mathrm{OEP}$ (16)

5,15-dinitrooctaethylporphyrin

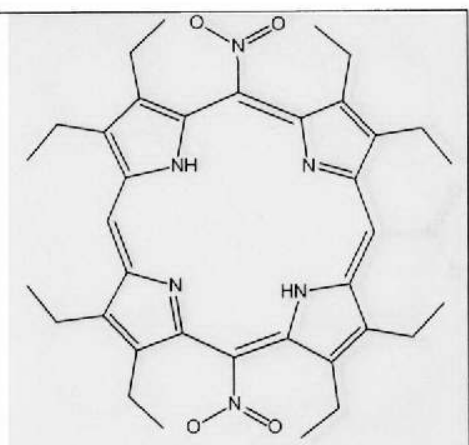

$\mathrm{H}_{2}$ 5,10,15-triNO 2 OEP (17)

5, 10, 15-trinitrooctaethylporphyrin

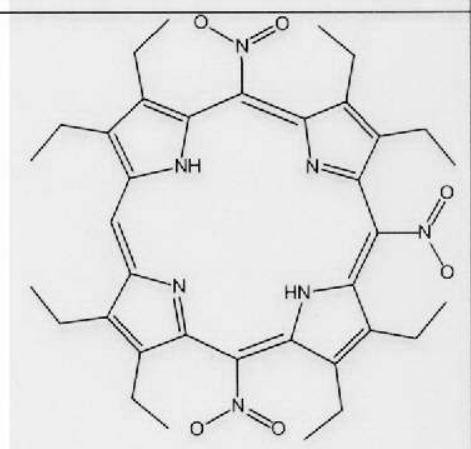

$\mathrm{H}_{2} 5,10,15,20$-tetra $\mathrm{NO}_{2} \mathrm{OEP}$ (18)

5,10,15,20-tetranitrooctaethylporphyrin

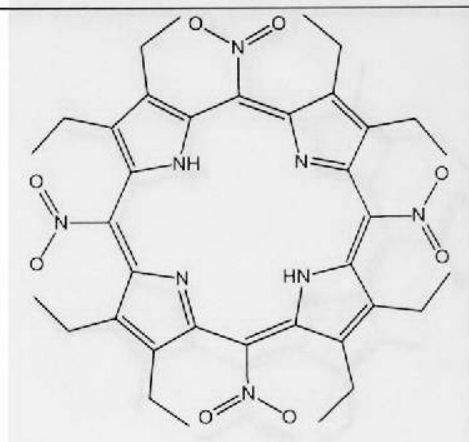

$\mathrm{H}_{2} 5-\mathrm{NO}_{2}$ ETIO1 (19)

5-nitroetioporphyrin-I

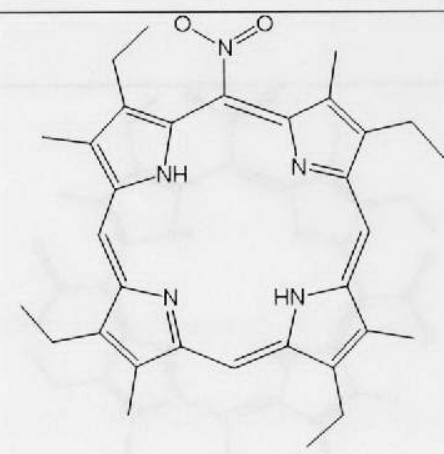


$\mathrm{H}_{2} 5,10$-diNO 2 ETIOI (20)

5,10-dinitroetioporphyrin-I

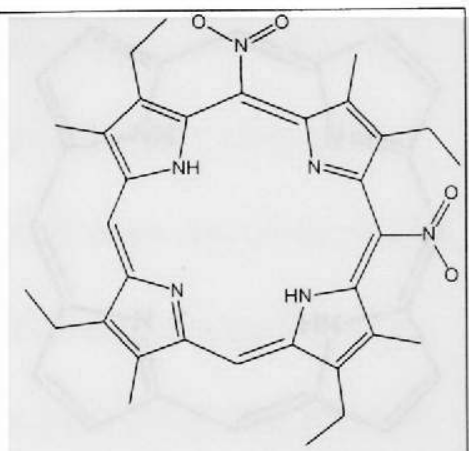

$\mathrm{H}_{2} 5,15$-diNO 2 ETIOI (21)

5,15-dinitroetioporphyrin-I

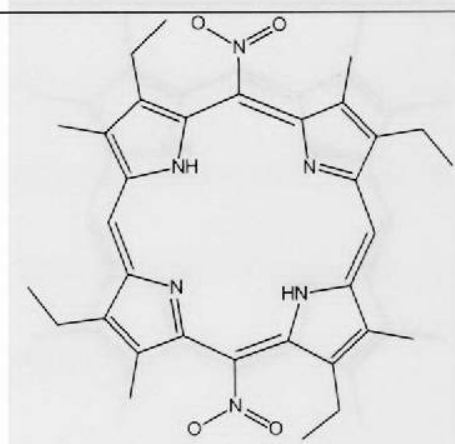

$\mathrm{H}_{2} 5,10,15$-triNO 2 ETIOI

5,10,15-trinitroetioporphyrin-I

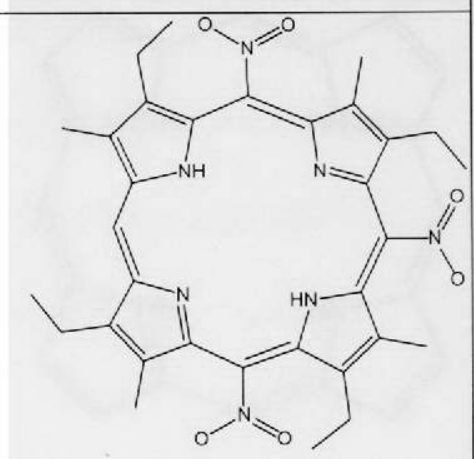

$\mathrm{H}_{2} 5,10,15,20$-tetraNO $\mathrm{O}_{2}$ ETIOI

$5,10,15,20$ - tetranitroetioporphyrin-I

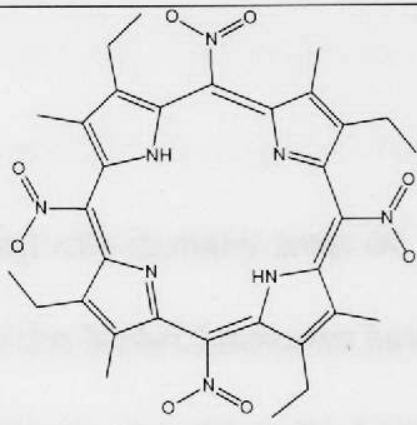


$\mathrm{H}_{2} \mathrm{P}$

(24)

Porphine

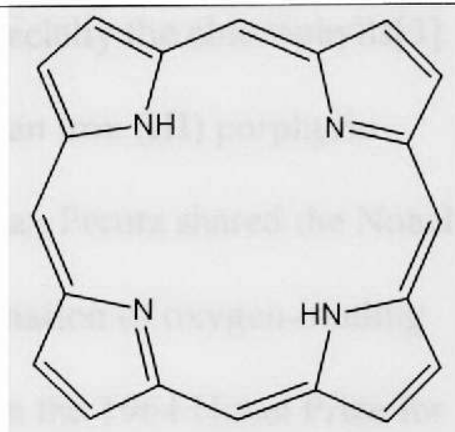

$\mathrm{H}_{2} \mathrm{OMP}$ (25)

Octamethylporphyrin

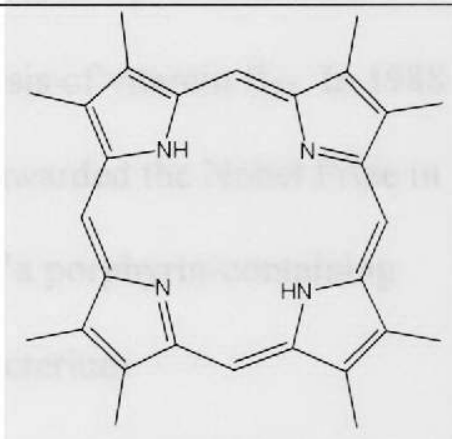

$\mathrm{H}_{4} \mathrm{P}^{2+}$

(26)

Porphyrin dication

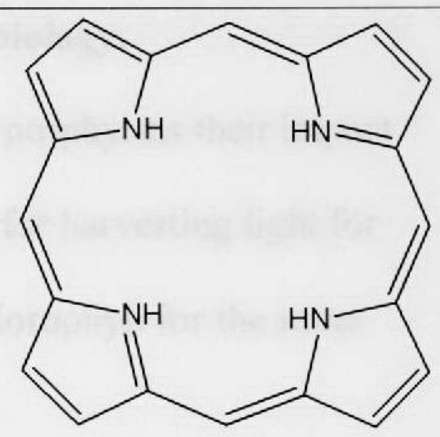

\subsection{Importance of porphyrins and related compounds}

Porphyrins and their related compounds have played a crucial role in many areas of chemistry and other sciences as discussed below.[3] In fact 6 of the Nobel Laureates have been awarded their prizes directly or indirectly for work in porphyrin chemistry: Richard Martin Willstätter won the Nobel Prize in chemistry in 1915 for his work on the 
purification and structural determination of plant pigments, specially the chlorophylls[3]. Hans Fischer in 1930 for his work on the structures of hemin, an iron (III) porphyrin pigment derived from hemoglobin[4-6]. John Kendrew and Max Perutz shared the Nobel Prize in 1962 for their work in X-ray crystallographic determination of oxygen-binding proteins hemoglobin and myoglobin[3]. Dorothy Hodgkin won the 1964 Nobel Prize for her work on X-ray crystallographic determination of vitamin $\mathrm{B}_{12}$ and penicillin and Robert Woodward won the Nobel Prize in 1965 for the synthesis of vitamin $B_{12}$. In 1988 Robert Huber, Johan Deisenhofer, and Hartmut Michel were awarded the Nobel Prize in chemistry for their crystallization and structural elucidation of a porphyrin-containing membrane protein complex from the purple photosynthetic bacterium Rhodopseudomonas viridis[7].

\subsection{Importance of porphyrins in biological chemistry and biology.}

Although there are only a few types of naturally occurring porphyrins their impact has been massive. Chlorophyll, a dihydroporphyrin, is critical for harvesting light for photosynthesis. Some photosynthetic bacteria used bacteriochlorophyll for the same purpose.[2]

Heme, the iron pigment of protoporphyrin-IX, is incorporated into many protein systems. For example, in hemoglobin and myoglobin, the heme acts as a transporter of oxygen. In cytochromes the Fe heme participates in electron transfer by cycling between $\mathrm{Fe}^{2+} \& \mathrm{Fe}^{3+}$. In the cytochromes $\mathrm{P} 450$, the $\mathrm{Fe}$ heme is central to their role in activating oxygen or hydrogen peroxide in order to insert an oxygen atom into an organic substrate.[8] One of the most important roles of cytochromes P450 is to convert 
insecticides, carcinogens, additives and pollutants into water - soluble metabolites which can be easily excreted.

\subsection{Porphyrins and related compounds in medicine.}

Errors in the metabolism of porphyrins give rise to severe health problems. In premature babies, neonatal jaundice is the result of hyperactive heme oxygenase which sequentially decomposes heme to form the bile pigments biliverdin and bilirubin, the cause of the characteristic yellow coloration associated with jaundice. In porphyria, there is again a breakdown in the metabolism resulting in the excretion of uroporphyrin-III, which is a precursor to protoporphyrin-IX. This causes the urine to turn red[9, 10].

Recently, porphyrins and others cyclic tetrapyrroles have been used as photosensitizers in photodynamic therapy (PDT). This therapy is of great promise for treatment of cancer it is site specific such as hair loss. PDT involves the photochemical generation of singlet oxygen from triplet oxygen via irradiation of a photosensitizer that is adsorbed on the malignant cells. The singlet oxygen destroys the cells with minimal side effects.

\subsection{Porphyrins and Inorganic Chemistry}

The four nitrogens in the core of the macrocycle are capable of chelating virtually any metallic element in the periodic table. Once chelated, the metal markedly modifies the properties of porphyrin macrocycle. Among the most intriguing facets of metalloporphyrin chemistry is their potential to act as catalysts. For example: a system containing of of porphyrins has been prepared as a model for the origin of photosynthesis on the primordial earth[11]. Chiral ruthenium porphyrins have been used as catalysts in the highly enantioselective synthesis of cyclopropylphosphonates[12]. 
Porphyrin systems are also proving of great interest in nanotechnology. For example, Shelnutt and coworkers created nanotubes that are micrometers in length and 50-70 nm in diameter by ionic self assembly of two oppositely charged porphyrin units. [13, 14] The porphyrinic nanotubes photo- catalytically grow metal structures onto the tube structures to create a functional nanodevice. The hope is that these nanotube devices could be suspended in solution and used for photocatalytic solar hydrogen production.

\subsection{Porphyrins and Geology.}

Geoporphyrins (geologically occurring porphyrins) played important roles in founding of molecular organic geochemistry. The discovery of pophyrins in crude oil established both the biological origin of petroleum, and the upper limit for the temperature of formation of petroleum. $[15,16]$

The discovery of porphyrins in a wide range of geological sources including petroleum's, coals, and oil shakes, was a landmark in petroleum geology. Alfred Treibs proposed that the geoporphyrins were the degradation products of biologically occurring cyclic tetrapyrroles-notably heme and chlorophyll. The concept that biological molecules undergo modification of their functional groups to form similar compounds with a alkyl/aryl units in place of functionalities lies at the heart of molecular organic geochemistry. Geoporphyrins are too complex to be made by random chemical processes. This indicates that petroleum is formed by decomposition of biological matter containing the porphyrins. Geoporphyrins are not thermally stable at $300^{\circ} \mathrm{C}$ for extended time. Thus, the petroleum must be made below this temperature $[15,16]$. 


\subsection{Porphyrin synthesis and synthetic porphyrins.}

Porphyrin synthesis is a unique area of synthetic organic chemistry.[1, 17] The synthetic routes to unsymmetrical porphyrins often involve as many as 20 steps. The reason for this is that each pyrrole subunit must be prepared separately, which may take several steps, then the units linked and finally they are cyclized to the porphyrin. Often these cyclizations occur in poor yield, $10-30 \%$. The syntheses of symmetrical porphyrins, which are the main focus of this thesis, are significantly less challenging. A single pyrrole must be prepared and this can either by cyclized into the porphyrin directly, or it can be cyclized along with a one - carbon unit, which forms the meso- carbon. Symmetrical porphyrins can be subdivided into three categories, symmetrical octaalkylporphyrins without meso-substituents, meso tetrasubstituted porphyrins without $\beta$-pyrrole substituents, and dodecasubstituted porphyrins each of which will be discussed. $[1,17$, 18]

\subsubsection{Syntheses of symmetrical octaalkylporphyrins without meso substituents.}

For the synthesis of octaalkyl porphyrins, such as $\mathrm{H}_{2} \mathrm{OEP}$, there are two different strategic approaches, the first involves the tetramerization of 2, 5-diunsubstituted pyrroles in the presence of a one carbon reaction such as formic acid or formaldehyde, which supplies the meso- carbons of the product. The second approach is the tetramerization of pyrroles bearing $2-\mathrm{CH}_{2}-\mathrm{R}$ substituents, the methylene carbon of which will be the 5,10 , 15 , and 20- carbons of the desired porphyrin. For example the dimethylamino porphyrin (Figure 3) forms $\mathrm{H}_{2} \mathrm{OEP}$ on heating in acetic acid. These methods have been recently reviewed by Kevin Smith.[17] 


\subsubsection{Syntheses of meso tetrasubstituted porphyrins without $\beta$-pyrrole substituents.}

$5,10,15,20$-tetraphenylporphyrin $\left(\mathrm{H}_{2} \mathrm{TPP}\right)$ was first synthesized by Rothemund in 1936 by condensation of pyrrole with arylaldehydes in methanol at various temperatures in sealed vessels.[19] The conditions were harsh and only some very stable aromatic aldehydes successfully result in porphyrin formationby this procedure. In 1967 Alder and Longo improved the method by refluxing in propionic acid in the open atmosphere for 20 minutes. [20, 21]
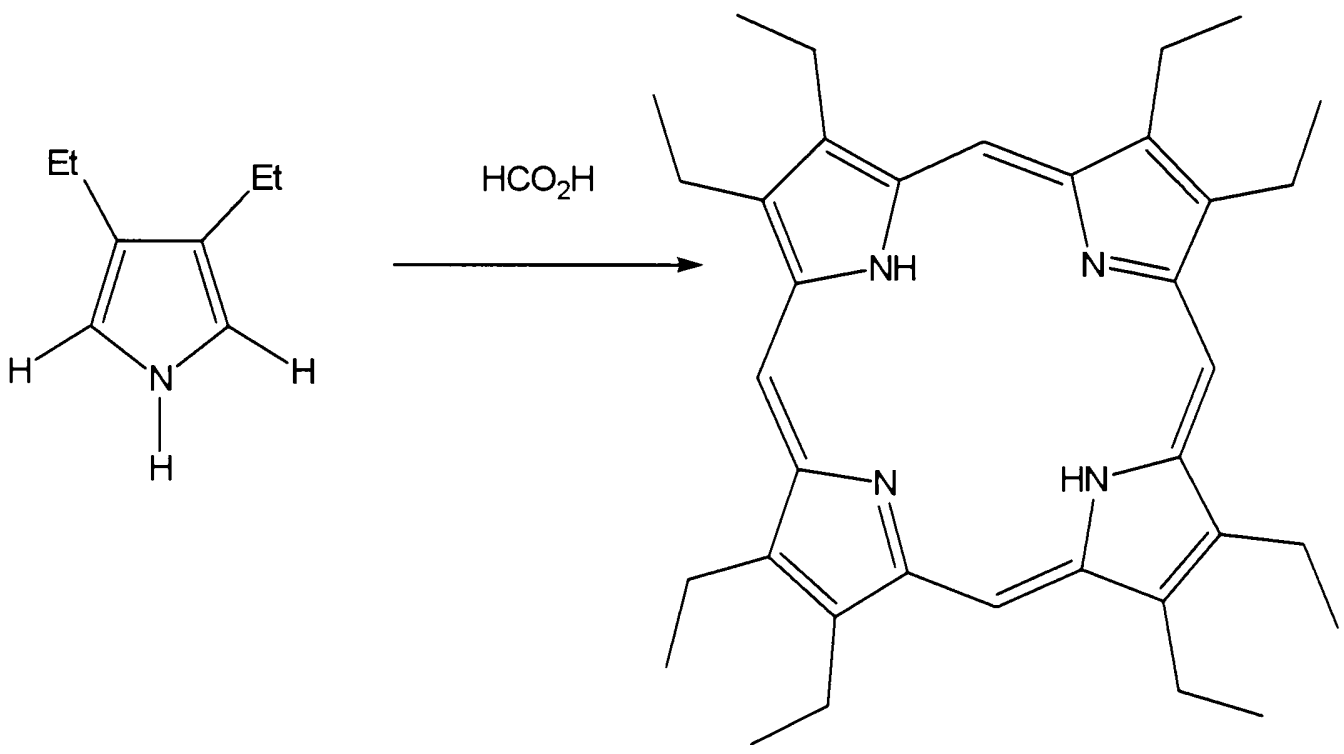

Figure $3 . \mathrm{H}_{2} \mathrm{OEP}$ synthesis from 2,5-diunsubstituted pyrroles in the presence of formic acid. 
A greater variety of substituted tetraphenylporphyrins were created and this is still the method of choice when large amounts of porphyrins are needed and the aldehydes are able to withstand the acidic conditions (Figure 4). Development of these synthetic methods resulted in the synthesis of a large variety of porphyrins, however, it is difficult to make porphyrins other than those which are tetra- substituted at the meso positions. A modified method was developed by Lindsey.[22] This method replaced the refluxing propanoic acid with trifluoroacetic acid (TFA) and methylene chloride $\left(\mathrm{CH}_{2} \mathrm{Cl}_{2}\right)$ followed by oxidation with DDQ, dichlorodicyanoquinone (Figure 4). It must be carried out under dilute conditions in order to limit the formation of open chain compounds thereby limiting the yield of the desired porphyrin.
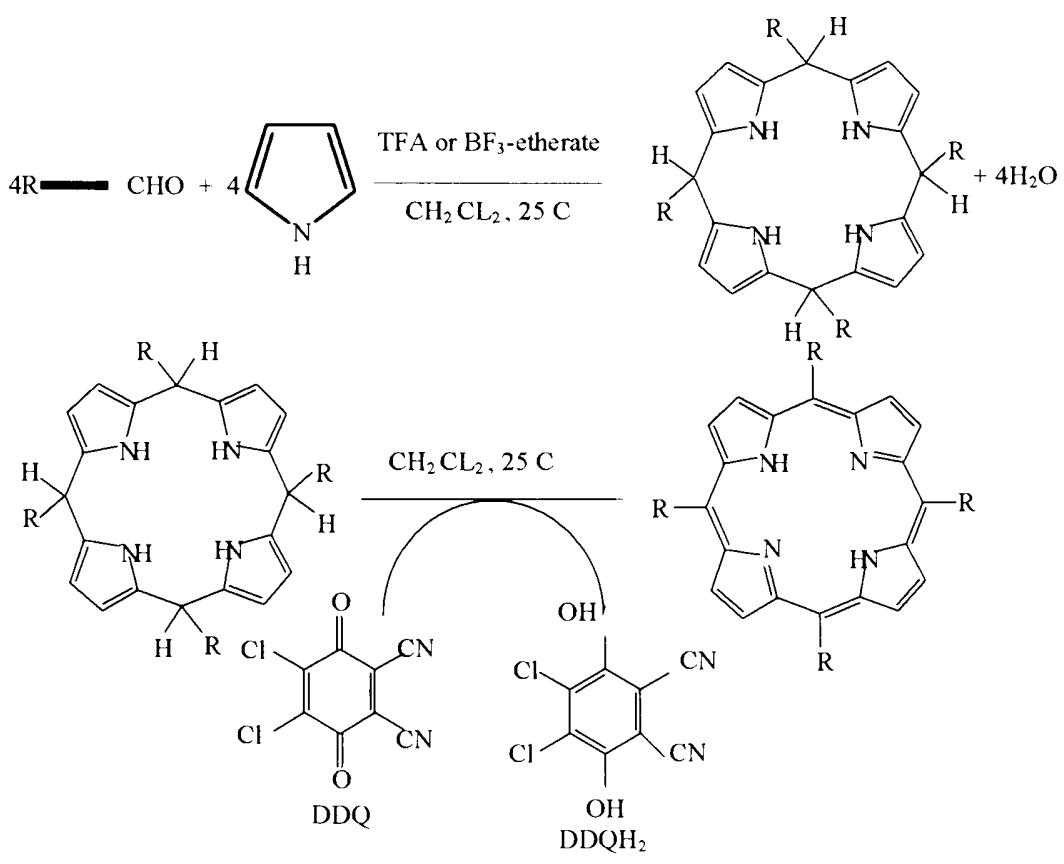

Figure 4. Two-step one-flask room-temperature synthesis of meso-substituted porphyrins. Note that four structural isomers of the porphyrinogen are expected (not shown). $\mathrm{R}=$ phenyl group. 


\subsubsection{Syntheses of dodecasubstituted porphyrins.}

\subsubsection{Syntheses of dodecaalkylporphyrins.}

The first porphyrin bearing twelve alkyl residues was prepared by the Rothemund reaction of 3,4-dimethylpyrrole with benzaldehyde in refluxing acetic acid. Presently or today such compounds are made using Lindsey conditions. Other dodecasubstituted porphyrins can be made by modification of octaalkylporphyrins by electrophilic substitution reaction such as nitration, and halogenation. Dodecaalkylporphyrins or dodecaalkyl/arylporphyrins can be prepared by introduction of alkyl/aryl units on $\beta$ bromo or meso - bromo porphyrin precursors using coupling reactions such as Suzuki cross coupling. In more recent attempts to prepare dodecaalkylporphyrins Medforth et al. reported a synthesis of $5,10,15,20$-tetraalkylporphyrins with different sized $\beta$ cycloalkenyl rings[23]. These studies showed that highly distorted non- planar dodecaalkylporphyrins are not acessible via classic pyrrole condensation methods and a different approach was described by Kalisch and Senge using organolithium compounds.

During this process the mono meso substituted compound is formed and subsequent nucleophilic attack, hydrolysis with water and oxidation with DDW produces the respective porphyrin.

\subsubsection{Syntheses of dodeca(alkyl/aryl)porphyrins}

The syntheses of several symmetric dodeca(alkyl/aryl)porphyrins is easily available form the respective pyrrole bearing the $\beta$-substituents and the appropriate aldehydes bearing the meso substituents. 


\subsection{Spectroscopic properties of porphyrins.}

Discussion is centered on UV-Vis and ${ }^{1} \mathrm{H}$ NMR spectra of porphyrins because these are the methods described in this dissertation.

\subsubsection{UV-Vis Spectroscopy.}

The brightly colored porphyrins have very characteristic visible spectra. They are most useful for diagnosing whether a porphyrin is neutral, a dication or a metal complex, as discussed below. All the bands in the visible spectra of porphyrins originate from $\pi-\pi^{*}$ transitions.[1] However, the precise nature of the transitions is exceedingly complex and lies outside the scope of this thesis.

Metal - free porphyrins display 5-banded spectra. There is a very intense band at about $400 \mathrm{~nm}$, the Soret, or $\mathrm{P}$ band. Typically, this has an extinction coefficient of more than 100,000 . In addition, there are 4 other less intense bands, usually ranging from about $500 \mathrm{~nm}$ to about $650 \mathrm{~nm}$. The ratio of these 4 bands (Q bands) and their peak positions depend on the nature of the substituents. In this work most of the metal - free porphyrin spectra are of the etio- type spectra in which the intensity of the peaks steadily decreases from the approximately $500 \mathrm{~nm}$ peak (band $1 \mathrm{~V}$ ) to the $620 \mathrm{~nm}$ peak (band I). The spectrum of $\mathrm{H}_{2} \mathrm{OEP}$ (Figure 6) is typical of such compounds.[1, 23]

In porphyrin dications, the Soret band is maintained, but the $4 \mathrm{Q}$ bands are sharply modified. The spectrum of the dication of $\mathrm{H}_{2} \mathrm{OEP}$ (Figure 7) is used as an example of a dication. Dications spectra are more variable than the neutral porphyrins. [1, 23] 


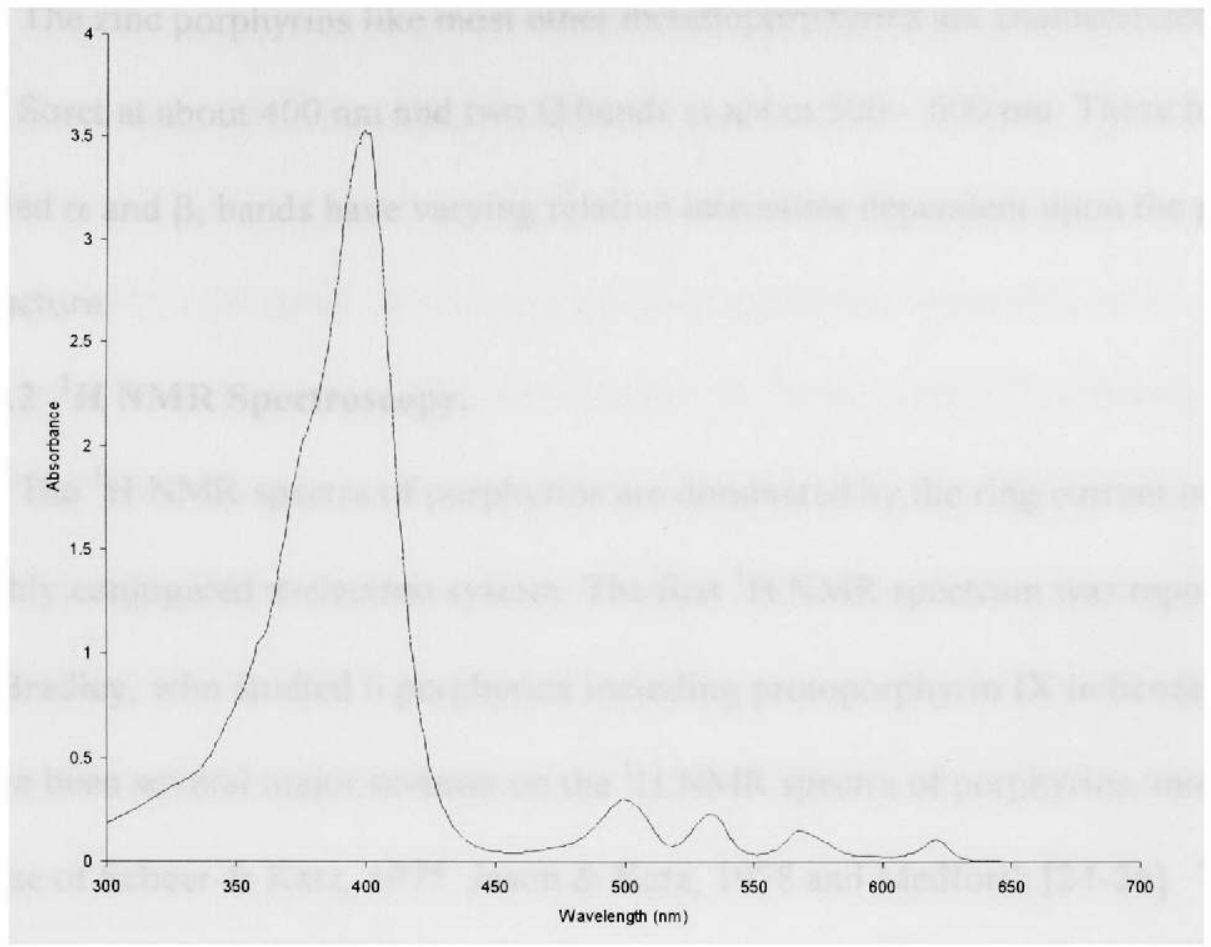

Figure 5. $\mathrm{H}_{2} \mathrm{OEP}$ spectrum in $\mathrm{CH}_{2} \mathrm{Cl}_{2}$.

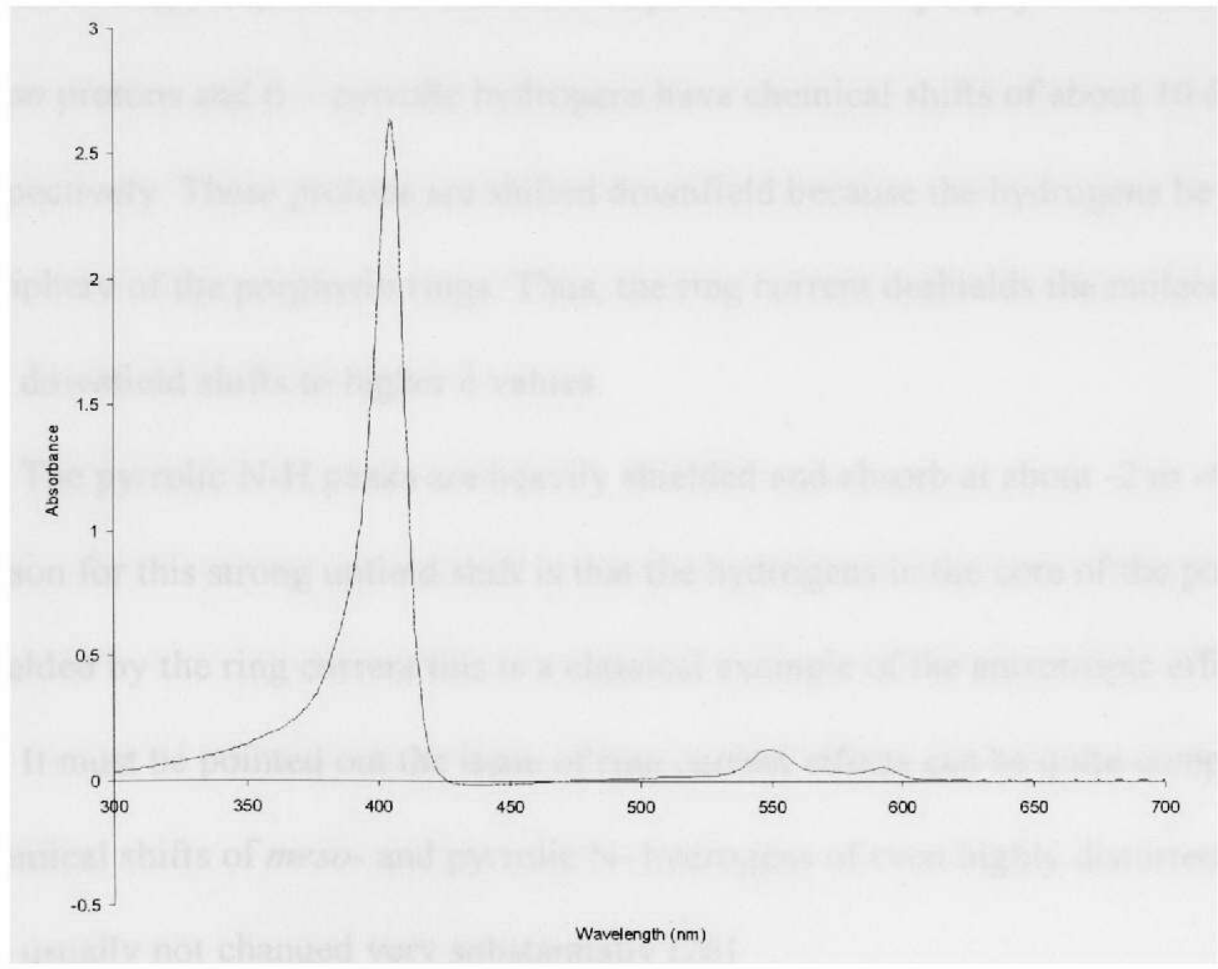

Figure 6. $\mathrm{H}_{4} \mathrm{OEP}^{2+}$ in TFA/CH $\mathrm{Cl}_{2}$ 
The zinc porphyrins like most other metalloporphyrins are characterized by 3 bands, the Soret at about $400 \mathrm{~nm}$ and two Q bands at about $500-600 \mathrm{~nm}$. These bands, also called $\alpha$ and $\beta$, bands have varying relative intensities dependent upon the porphyrin structure

\subsection{2 ${ }^{1}$ H NMR Spectroscopy.}

The ${ }^{1} \mathrm{H}$ NMR spectra of porphyrins are dominated by the ring current owing to the highly conjugated $\pi$-electron system. The first ${ }^{1} \mathrm{H}$ NMR spectrum was reported by Becker \& Bradley, who studied 6 porphyrins including protoporphyrin IX in benzene. There have been several major reviews on the ${ }^{1} \mathrm{H}$ NMR spectra of porphyrins, most notably those of Scheer \& Katz, 1975, Jason \& Katz, 1978 and Medforth.[24-26] The chemical shifts of unsubstituted $\beta$ - pyrrolic hydrogens, meso- hydrogens, and pyrrolic N $\underline{H}$ protons are all strongly dependent on the anisotropic effect of the porphyrin $\pi$-electron system. Meso protons and $\beta$ - pyrrolic hydrogens have chemical shifts of about $10 \delta$ and $8-9 \delta$, respectively. These protons are shifted downfield because the hydrogens lie on the periphery of the porphyrin rings. Thus, the ring current deshields the molecule and causes the downfield shifts to higher $\delta$ values.

The pyrrolic N-H peaks are heavily shielded and absorb at about -2 to $-4 \delta$. The reason for this strong upfield shift is that the hydrogens in the core of the porphyrins are shielded by the ring current this is a classical example of the anisotropic effect.

It must be pointed out the issue of ring current effects can be quite complex. The chemical shifts of meso- and pyrrolic N- hydrogens of even highly distorted porphyrins are usually not changed very substantially.[26] 
A further complication in the ${ }^{1} \mathrm{H}$ NMR spectra of porphyrins is the fact that the molecules undergo tautomerization (Figure 7). For symmetrical porphyrins, it is not possible to distinguish between the pyrrolic NH's on either tautomer since they are magnetically equivalent. For asymmetrical porphyrins it is possible to do so, but only if the rate of tautomerization is slower than the NMR time scale. Thus low temperature ${ }^{1} \mathrm{H}$ NMR studies can be used to resolve these hydrogens[27-30]. Additionally, by carrying out variable temperature ${ }^{1} \mathrm{H}$ NMR studies it is possible to identify the coalescence temperature at which the NH signals become a singlet. This temperature plays a key role in measuring the free energy of tautomerization, which will be discussed in a subsequent chapter.

In symmetrical porphyrins the $\beta$ - pyrrolic, and the hydrogens on $\beta$ - substituents may also be magnetically distinguishable, depending on the state of protonation of the corresponding pyrrole groups. These signals may also be studied by variable temperature ${ }^{1} \mathrm{H} N M R$ as will be discussed for $\mathrm{H}_{2} 5,10,15$-triNO${ }_{2} \mathrm{OEP}$. The $\Delta \mathrm{G}^{*}$ may yield valuable information concerning the extent of intramolecular hydrogen bonding which exists in the porphyrin core. $[26,27,31]$

\section{$1.10 \mathrm{NH}$ Tautomerism in porphyrin systems}

NH Tautomerism in porphyrin systems was first described by Storm[32] in 1972. It consists of an intramolecular two proton transfer and is shown in Figure 7. It has been the subject of numerous investigations using nuclear magnetic resonance and theoretical studies. 
$\mathrm{H}$ - bonded

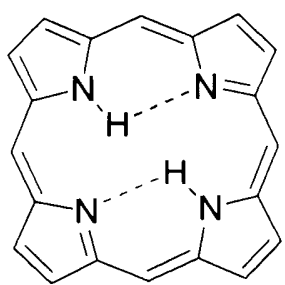

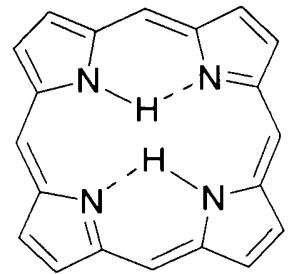

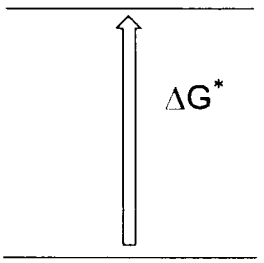

$\mathrm{H}$ - bonded

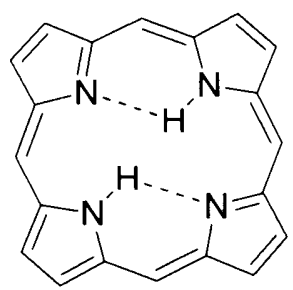

Figure 7. Tautomerization.

The focus of these studies has been to determine if the mechanism is a synchronous (simultaneous, concerted) two proton transfer, or asynchronous (two step mechanism) involving transfer of one proton followed by transfer of the second proton. [33, 34] Evidence has been presented for both mechanisms and indeed in different porphyrin systems one mechanism may prevail over another. Recent studies have favored an asynchronous mechanism rather than a synchronous one for most porphyrin systems.

The activation energy towards tautomerization is a constant $50 \mathrm{~kJ} /$ mole for most of the systems studied. It is not influenced by the presence of electron withdrawing groups in the periphery.[26, 31] These will affect both the ground and activated states to the same extent and will not cause a change in the activation energy. The conformation of the porphyrin ring however does influence the activation energy.[35] Systems such as 
the dodecasubstituted porphyrins show greater activation energy towards tautomerization and those which are severely ruffled show a much reduced energy of activation. [26, 31] This is presumably due to the increased hydrogen bonding interaction in these systems versus the dodecasubstituted systems. Regardless of the mechanism of tautomerization, extent of intramolecular hydrogen bonding should affect the energy of activation towards tautomerization.

\subsection{Calorimetry studies.}

The word calorimetry literally means measurement of heat. A calorimeter measures the heat generated or absorbed in a chemical process. By measuring these heats we can investigate the relative thermodynamic stability of many chemical compounds.

There are various types of calorimeters used in chemistry: the isoperibol or constant pressure calorimeter, the bomb or constant volume calorimeter and the heat flux calorimeter are just three of the most useful ones. [36] With the bomb and isoperibol calorimeters the temperature changes are measured. Then with knowledge of the heat capacity of the heat absorbing medium, the $\Delta \mathrm{E}$ and $\Delta \mathrm{H}$ of the processes are measured.

In 1923 Tian built the first heat flux calorimeter with a single calorimeter vessel, the surroundings serving as a reference. In heat flux calorimetry the flow of heat from the calorimeter cell is determined by using thermocouples placed in such a way as to surround the calorimeter cell. Since the current is related to the difference in temperature on both sides of the thermocouple, the current will flow until both sides are at the same temperature. The current is measured and can be related to the heat flowing from the cell to the isothermal block. The isothermal block is of high heat capacity so the temperature of the block does not change significantly. Calvet (1948) extended this 
design by placing two equal systems in an isothermal block (thermostat). One system was the reference cell and the other is the sample cell.[37] Both systems are identical in every way possible except for the absence of the components necessary for the process being studied to take place. By subtracting the heat from the reference cell from that of the sample cell and integrating over the duration of the process the $\Delta \mathrm{H}$ is measured.

Thermodynamic studies in porphyrin chemistry are not ubiquitous. Enthalpies of solution in various solvents of $\mathrm{H}_{2} \mathrm{TPP}$ and several natural porphyrins have been obtained by Berezin's group. They used mixed solvents so their data is not directly applicable to our study. [38-40] Standard enthalpies of combustion of several porphyrins have been determined but these are solid forms of porphyrins and not directly relevant to our work. [41]

\section{Conformations in porphyrins.}

\subsection{Relevance to biological systems}

There are numerous enzymes that have a porphyrin at the active site. It has long been recognized that these are significantly distorted from planarity and it is speculated that these nonplanar distortions play a role in their biological functions.[42-46] In fact, it is found that for proteins with the same function across many different species, the types of distortions are essentially conserved[43]. Of 70 , different peroxidases, from different species and different enzyme types, it is found that the conformation of the porphyrin macrocycle is conserved[47]. Since it takes energy to distort a porphyrin, this suggests that such distortions modulate the biological function. [48] For example across species the heme of the deoxy form of myoglobin is found with the Fe slightly above the heme group 
and the pyrrole nitrogens pointing upward towards the $\mathrm{Fe}$. The heme of cytochromes $\mathrm{C}$ peroxidase is observed to have opposing pairs of pyrrolic nitrogens pointing in opposite directions. Myoglobin's function is carrying oxygen intact to the cell for respiration; the function of cytochrome $\mathrm{c}$ peroxidase is the reduction of hydrogen peroxide to water. The function of several cytochromes $\mathrm{c}$ is electron transfer, the heme group is found in yet another conformation. In all these processes similar iron porphyrins are encapsulated in different polypeptide environments and are able to perform different functions. The conformation of the porphyrin varies depending on the function of the particular protein or enzyme in question. [44]

Enzymes are most efficient catalysts. The porphyrin groups in most of these enzymes do not have the "ideal" or lowest energy planar structure. This structure is too stable for the catalyst to be efficient. Enzymes are believed to maintain their active site in a "close to activated state" so that minimal effort is all that is needed for the wanted reaction to take place and for it to occur in either direction.[49] It is believed that the combination of secondary, tertiary and quaternary structures of the protein maintain their active sites in an activated state, presumably taxing the greater stability elsewhere in the protein molecule. This has been designated in the past as the entatic (or energetic) state. $[49,50]$

\subsection{Variations in porphyrin conformation}

There are several ways by which nonplanarity can be induced in porphyrins. These include metal and axial ligand effects, core substitution, overloading the periphery with sterically demanding substituents, exchanging macrocycle atoms for larger heteroatoms, interruption of the aromatic system, reduction and strapping the macrocycle[51]. In this 
dissertation the emphasis will be on porphyrins in which nonplanarity is induced via steric effects at the periphery.

Scheidt[52] originally proposed the description of porphyrin conformations outlined in Figure 8. In order to emphasize their differences, a "3-dimensional" picture of what the molecule looks like is included below each diagram. Porphyrins with no substituents tend to be planar. The term deformation refers to deviation from planarity. When the molecule is not planar, then we draw a "mean" plane with parts of the porphyrin ring situated above or below this plane. In the idealized diagrams shown in Figure 8, any atom designated by an open circle is situated below the mean plane of the ring, any atom designated by a closed circle is situated above the mean plane and any atom which is designated by the intersection of two bonds (no circle) is in the mean plane.

For example in the saddled conformation, the meso carbons define the mean plane and the pyrrole rings alternate above and below this mean plane. Porphine, $2,3,7,8,12,13,17,18$-octamethylpophyrin $\left(\mathrm{H}_{2} \mathrm{OMP}\right)$ and $2,3,7,8,12,13,17,18$ octaethylpophyrin $\left(\mathrm{H}_{2} \mathrm{OEP}\right)$ are examples of planar porphyrins. In the domed conformation (dom) configuration the meso carbons are in the mean plane of the macrocycle, all the pyrrolic nitrogens are above the mean plane and the $\beta$ carbons are below the mean plane. 


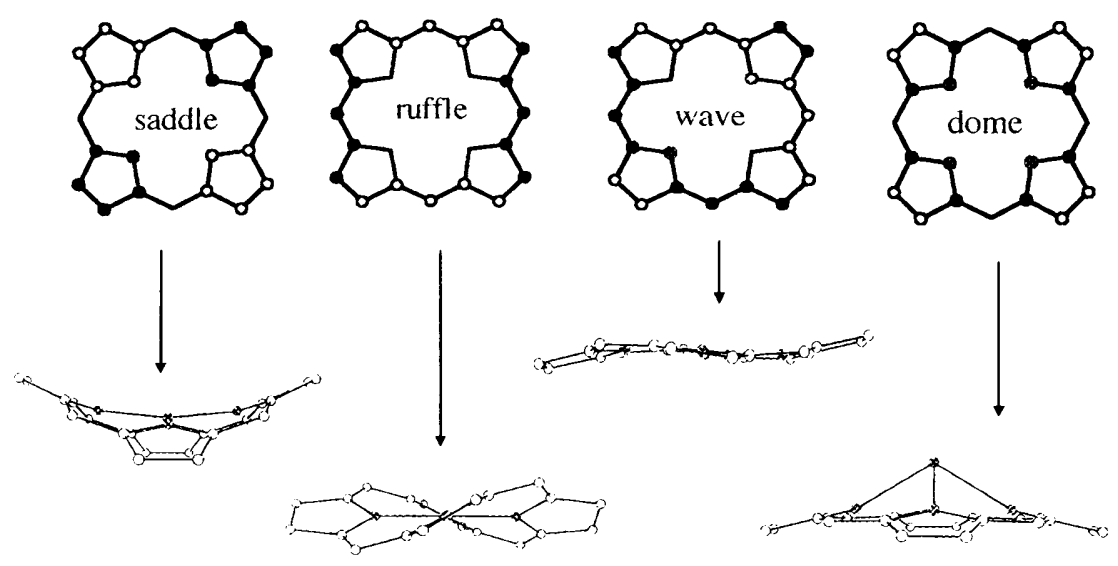

open circle $=$ above mean plane closed circle $=$ below mean plane no circle $=$ in mean plane

Figure 8. Non- planar distortions in porphyrins.

The doming distortion is found mainly in five coordinate metalloporphyrin complexes, where the axial ligand causes an out of plane displacement of the central metal ion or when an atom is too large to fit in the macrocycle.[53]

In the ruffled (ruf) conformation, the pyrrolic nitrogens are in the mean plane of the macrocycle, while each pyrrole ring tilts in such a way as to minimize the nitrogennitrogen distance. The nitrogen distances are reduced for opposite and adjacent nitrogens. Each pyrrole ring will have one $\alpha$ and one $\beta$ carbon above and the other $\alpha$ and $\beta$ carbons below the mean plane. This is most famously adopted by NiOEP. The metal nitrogen bond distances are presumably shortened to accommodate the radius of the $\mathrm{Ni}-\mathrm{N}$ bond. 
In the saddled (sad) conformation each pyrrole ring is either above or below the mean plane as shown in Figure 8. One example is the dodecasubstituted porphyrin, 5,10,15,20tetraphenyl-2,3,7,8,12,13,17,18-octaethylporphyrin $\left(\mathrm{H}_{2} \mathrm{OETPP}\right)$. The meso carbons are approximately in the mean plane of the macrocycle. In the wave (wav) conformation half of a conjugative path is above the mean plane and the other half below the mean plane where an imaginary line divides the opposite pyrroles in half. Each pyrrole ring will have one $\alpha$ and one $\beta$ carbon above and the other pair below the mean plane. The pyrroles outside the conjugative path will have one $\beta$ carbon above the mean plane and the opposite pyrrole has the $\beta$ carbon below the mean plane. The nitrogens are in the mean plane of the ring.

In symmetrically substituted free base porphyrins, only the planar, ruffled and saddled conformations are observed. Asymmetrically substituted free base porphyrins may also show the wave conformation. The domed conformation is observed mainly in metalloporphyrin complexes.

\subsection{X-ray crystal studies.}

A large number of X-Ray structures have been determined and examined according to substitution patterns at the periphery of the porphyrin and metalloporphyrin macrocycle.[52] The first X-ray crystal structure of a free-base porphyrin was of $\mathrm{H}_{2}$ TPP. Two crystal forms were determined, a triclinic form which is essentially planar and a tetragonal form which was not planar. [55-57]. The tetragonal form is believed to be the result of crystal packing and metalloporphyrin impurities setting the environment for further deposits of free-base porphyrins in that crystal form. The crystal structure of pure free-base $\mathrm{H}_{2}$ TPP is believed to be essentially planar where the phenyl groups are rotated 
more than $60^{\circ}$ out of the plane of the macrocycle. The phenyl groups rotate to avoid interference with the pyrrole hydrogen atoms, [57]; they may be held in that conformation by crystal packing forces. The X-ray crystallographic structure of octaalkyl substituted porphyrins was first explored with $\mathrm{H}_{2} \mathrm{OEP}$ indicating that the structures are similar to meso- substituted porphyrins but that the substituent groups on the macrocycle cause changes in the geometry where substitution occurred.[58] The X-Ray crystal structure of $\mathrm{H}_{2} \mathrm{OEP}$ shows that it also is a planar molecule. The vast majority porphyrin X-Ray crystal structures available in the literature are for metalloporphyrin complexes. The chelated metal ion makes it easier to generate the crystal necessary for X-Ray studies. It is sometimes unclear what the structure of the macrocycle would be in the absence of the metal and crystal packing forces. Many of these structures have been recently compiled by Senge.[59]

\section{Molecular modeling in porphyrin systems}

Molecular modeling uses graphical, mathematical, or physical representations of molecules to predict their structure and properties. Computational chemistry, inherently linked to progress in the computer industry, not only includes quantum mechanics but also molecular mechanics, different methods of minimization and conformational analysis. All of these methods are used in molecular modeling. All of them have also been used in the modeling of porphyrin compounds. Because of their size and complexity, ab initio methods using any additional substituents are very difficult to carry out. Only recently has it become possible to study the electronic effects of peripheral substituents on the porphyrin macrocycle using these methods. For this reason simpler 
methods are used. Only the most generally recognized approaches: molecular mechanics $\mathrm{MM}+$, density functional, and the semiempirical method will be described here.[23, 6062]

3. 1 Molecular mechanics or force field method is an empirical method based on the ball and spring model of molecular structures.[62] The sizes of the balls and stiffness of springs is determined empirically and are chosen to represent experimental data. This interaction between the ball and spring causes bond strain energy. Another more important source of energy is the steric strain energy. It has been, in the last fifty years, extensively used to quantitate the role it plays in determining the conformational structure, and energy differences between conformations of a molecule. It is able to reproduce rotational barriers about single bonds as accurately as $a b$ initio methods in a fraction of the time. Electrons are not included in this model so it is not suitable for studies in electronic spectroscopy and photochemistry. Molecular mechanics cannot predict electronic structure and transitions; however these calculations can be carried out in large systems and with many initial structures, which is important for the shallow potential surfaces in porphyrins.

3.2 The semiempirical molecular orbital method uses equations to approximate molecular orbitals. These approximations account for electron correlation energies. Semiempirical methods consider only the valence electrons of the system, treating the core electrons as part of the nuclear core. These approximations are chosen to best fit experimental data and make possible their use in larger systems as the calculation time is considerably reduced. 
3.3 Density functional theory is based on Hohenberg and Kohn theory (1964) which states all the ground state properties of a system are functions of the charge density. The total electronic energy is, in this model, a function of the electron density $\rho$ therefore given a known electron density; one could form the Hamiltonian operator, solve the Schrodinger equation, and determine the wave functions and energy eigenvalues. Hohenberg and Kohn theory has certain advantages over Hartree - Fock theory; it includes electron correlation indirectly, and scales better to system size. If $\mathrm{N}$ stands for the number of electrons in the system, then the time needed is proportional to $\mathrm{N}^{3}$ instead of $\mathrm{N}^{4}$ as in Hartree - Fock theory.[61] This leads to a considerable reduction in time necessary and an increase in the complexity of the molecule that may be studied. 


\section{Statement of the problem}

The purpose of this dissertation is to understand the influence of different macrocyclic conformations adopted by porphyrin compounds on the enthalpies of solution, relative basicities, ability to intramolecularly hydrogen bond and nmr spectral behavior of free-base porphyrins.

The enthalpies of solution and protonation of $\mathrm{H}_{2} \mathrm{OEP}$ (planar), $\mathrm{H}_{2} \mathrm{TPP}($ planar), $\mathrm{H}_{2} \mathrm{OETPP}$ (saddled), $\mathrm{H}_{2} \mathrm{OIP}$ (planar, slight ruffling), $\mathrm{H}_{2}$ ETIOI(planar), $\mathrm{H}_{2} \mathrm{~T}(\mathrm{nPe}) \mathrm{P}($ planar), $\mathrm{H}_{2} \mathrm{~T}$ (iPr)P(ruffled), $\mathrm{H}_{2} \mathrm{~T}(\mathrm{tBu}) \mathrm{P}($ ruffled) were obtained. All of these porphyrin free-bases have peripheral groups with similar Hammet sigma parameters. The main differences among them are the macrocyclic conformations they adopt.

To determine the role played by electron withdrawing groups placed along the periphery and the relative basicity of individual free-base porphyrins. For this purpose, $\mathrm{H}_{2} 5,10,15,20$-tetraNO ${ }_{2} \mathrm{OEP}$ (saddled), $\mathrm{H}_{2} 5-\mathrm{NO}_{2} \mathrm{OEP}$ and $\mathrm{H}_{2} \mathrm{~T}\left(\mathrm{nC}_{5} \mathrm{~F}_{5}\right) \mathrm{P}($ planar) will be studied.

To understand the effects of porphyrin conformation and electron withdrawing groups on other properties of porphyrin macrocycles, such as $\Delta \mathrm{G}^{*}$ for tautomerization and $\mathrm{nmr}$ spectral properties.

The macrocyclic conformation of around 20 different free base porphyrins will be determined using two methods: molecular mechanics and semi-empirical methods. The energy of this deformation will be determined by a single point energy calculation of the most stable conformation adopted by each different porphyrin compound. This information will be used to better understand the effects of macrocyclic conformation on the different properties of free base porphyrins. 


\section{Experimental}

$\mathrm{H}_{2} \mathrm{OEP}(5), \mathrm{H}_{2}$ TPP (8), $\mathrm{H}_{2}$ ETIOI(6) and $\mathrm{H}_{2} \mathrm{~T}\left(\mathrm{C}_{6} \mathrm{~F}_{5}\right) \mathrm{P}(12)$ were purchased from Aldrich. Meso nitro substituted $\mathrm{H}_{2}$ ETIOI (6), $\mathrm{H}_{2}$ OEP (5) compounds were synthesized via nitration of the zinc metallated porphyrins followed by chromatographic separations. Purity was determined via NMR, UV-Vis UV-Visible spectra and TLC (thin layer chromatography). [63, 64] [65] $\mathrm{H}_{2} \mathrm{OIP}$ (7) was obtained from Dr. J. Martin E. Quirke in Florida International University in Miami, FL. Meso substituted porphyrins such as $\mathrm{H}_{2} \mathrm{~T}(\mathrm{iPr}) \mathrm{P}(10), \mathrm{H}_{2} \mathrm{~T}(\mathrm{tBu}) \mathrm{P}(11), \mathrm{H}_{2} \mathrm{~T}(\mathrm{nPe}) \mathrm{P}$ (9) and $\mathrm{H}_{2} \mathrm{OETPP}$ (13) [66] were obtained from Dr. Craig Medforth, Sandia Laboratories in New Mexico.

\subsection{Free-base porphyrin synthesis.}

$\mathrm{H}_{2}$ 5- $\mathrm{NO}_{2} \mathrm{OEP}$ (14), $\mathrm{H}_{2} 5,15$-diNO 2 OEP (15), $\mathrm{H}_{2} 5,10$, 15-triNO ${ }_{2} \mathrm{OEP}$ (17), and $\mathrm{H}_{2} 5$, $10,15,20$-tetraNO${ }_{2} \mathrm{OEP}(\mathbf{1 8})$ and the analogs of $\mathrm{H}_{2}$ ETIOI were prepared by the method of Gong and Dolphin[65]. $\mathrm{H}_{2} 5,10-\mathrm{diNO}_{2} \mathrm{OEP}(16)$ and $\mathrm{H}_{2} 5$, 10-diNO $\mathrm{d}_{2}$ ETIOI was prepared by the method of Bonnett and Stephenson.[63]

ZnOEP solution: $\mathrm{H}_{2} \mathrm{OEP}(500 \mathrm{mg})$ was dissolved in $\mathrm{CH}_{2} \mathrm{Cl}_{2}(500 \mathrm{~mL})$ and Zinc acetate (490 mg) was dissolved in $\mathrm{CH}_{3} \mathrm{OH}(4 \mathrm{ml})$. The zinc acetate solution was added to the $\mathrm{H}_{2} \mathrm{OEP}$ solution. The mixture was stirred for at least two hours at which time it changed colors from brown to red as metallation occurred. Completion of the metallation reaction was verified using UV-Visible spectroscopy and monitoring the disappearance of the four Q bands and appearance of the two bands associated with the metallated porphyrin. $\mathrm{H}_{2}$ 5-NO2 $\mathbf{2 E P}(\mathbf{1 4}) \mathrm{NO}_{2}(7 \mathrm{~mL})$ stock solution $(0.32 \underline{\mathrm{M}})$ was added to the $\mathrm{H}_{2} \mathrm{OEP}$ solution and allowed to stir overnight. At that point an additional $8 \mathrm{~mL}$ of $\mathrm{NO}_{2}$ stock solution was added. After two hours most of the $\mathrm{ZnOEP}$ had been consumed producing 
Zinc 5-nitrooctaethylporphyrin. Another $1 \mathrm{ml}$ of $\mathrm{NO}_{2}$ solution was added and the solution was demetallated using trifluoroacetic acid (TFA) and washed three times with the addition of a saturated solution of $\mathrm{NaHCO}_{3}$. The organic phase was separated, washed with water $(3 \times 400 \mathrm{~mL})$, and taken to dryness on a rotary evaporator. The $\mathrm{H}_{2} 5-\mathrm{NO}_{2} \mathrm{OEP}$ was then dissolved in toluene $(15 \mathrm{~mL})$ and eluted with $4: 1$ hexane:toluene solution through a ten inch bed of alumina (200-400 mesh). The first elute was a yellow band containing decomposition products from the reaction. The solution was subsequently eluted with $3: 1$ hexane/toluene followed by $2: 1$ hexane toluene. The $\mathrm{H}_{2} 5-\mathrm{NO}_{2} \mathrm{OEP}$ eluted with $2: 1$ hexane/toluene. The remaining porphyrin band, eluted with $1: 1$ hexane/toluene or toluene, contained the unreacted OEP. The column was finally eluted with dichloromethane. The $\mathrm{H}_{2} 5-\mathrm{NO}_{2} \mathrm{OEP}(50 \%$ yield) was evaporated under vacuum and recrystallized from 1:1 dichloromethane/hexane and purity checked using UV-Visible spectroscopy and NMR spectroscopy. $\lambda\left(\mathrm{CH}_{2} \mathrm{Cl}_{2}\right)$ soret: 396 ; q-bands: $502,537,571$, 624; ${ }^{1} \mathrm{HNMR} \delta$ had: $10.2737,10.121\left(\right.$ meso-3H); $4.11\left(\mathrm{~m}, 12 \mathrm{H},-\mathrm{CH}_{2}-\right) ; 3.75\left(\mathrm{q}, 4 \mathrm{H},-\mathrm{CH}_{2}-\right.$ ); $1.93\left(\mathrm{~m},-\mathrm{CH}_{3}, 18 \mathrm{H}\right) ; 1.69\left(\mathrm{t}, 6 \mathrm{H},-\mathrm{CH}_{3}\right),-3.81(\mathrm{~s}, 2 \mathrm{H},-\mathrm{NH})$. Anal. Calculated for $\mathrm{C}_{36} \mathrm{H}_{45} \mathrm{~N}_{2} \mathrm{O}_{2}: \mathrm{C}, 74.58 ; \mathrm{H}, 7.82 ; \mathrm{N}, 12.08$; found: $\mathrm{C}, 74.20 ; \mathrm{H}, 7.84 ; \mathrm{N}, 11.94$. $\mathrm{H}_{2} 5$, 15-diNO $\mathrm{O}_{2} \mathrm{OEP}$ (15). The process is an extension of the preparation of $\mathrm{H}_{2} 5$ $\mathrm{NO}_{2} \mathrm{OEP}$ synthesis. After adding about $15-16 \mathrm{ml}$ of $\mathrm{NO}_{2}$ solution to obtain the $\mathrm{Zn} 5$ $\mathrm{NO}_{2} \mathrm{OEP}$ product as described above additional $\mathrm{NO}_{2}$ solution in increments of about $1-2$ ml were added monitoring the reaction by TLC. It is important to add the extra $\mathrm{NO}_{2}$ aliquots slowly because the reaction products seemed to revert to starting material during work. The final product is demetallated with TFA and washed several times with $\mathrm{NaHCO}_{3}$ and water before taken to dryness in the rotary evaporator. The product was 
subjected to column chromatography, following the method described above. The compounds were dissolved in toluene (about $10-15 \mathrm{ml}$ ). The first compounds eluted were the decomposition products, then the $\mathrm{H}_{2} 5,10,15,20$-tetraNO${ }_{2} \mathrm{OEP}$ elutes as a greenyellow band. This is followed by the $\mathrm{H}_{2} 5,10,15$-triNO ${ }_{2} \mathrm{OEP}$ and then the $\mathrm{diNO}_{2} \mathrm{OEP}$ isomers. This band is recrystallize which yields mainly the $\mathrm{H}_{2} 5,15-\mathrm{diNO}_{2} \mathrm{OEP}$. A final separation of the isomers is carried out using TLC eluting with 2:1 hexane/toluene. The first (top) band is the $\mathrm{H}_{2} 5,15$-diNO $2 \mathrm{OEP}$, the second band is $\mathrm{H}_{2} 5,10,15-$ triNO$_{2} \mathrm{OEP}$ byproduct and the third band is the $\mathrm{H}_{2} 5,10$-diNO $2 \mathrm{OEP}$. The $\mathrm{H}_{2} 5,15-\mathrm{diNO}_{2} \mathrm{OEP}$ is dried recrystallyzed from 1:1 methylene chloride/hexane and its purity was checked using UVVisible spectroscopy and NMR spectroscopy. Compound (15) $\lambda\left(\mathrm{CH}_{2} \mathrm{Cl}_{2}\right)$ soret: 381,394 ; q-bands: 507, 537, 578, 629; ${ }^{1} \mathrm{HNMR} \delta$ had: $10.36\left(\right.$ meso-2H) $; 4.10\left(\delta, 8 \mathrm{H},-\mathrm{CH}_{2}-\right) ; 4.71$ $\left(\delta, 8 \mathrm{H},-\mathrm{CH}_{2-}\right) ; 1.94\left(\tau, 12 \mathrm{H},-\mathrm{CH}_{3}\right) ; 1.70\left(\tau, 12 \mathrm{H},-\mathrm{CH}_{3}\right) ;-3.36(\delta, 2 \mathrm{H},-\mathrm{NH})$. $\mathrm{H}_{2} 5,10,15$-triNO $\mathrm{O}_{2} \mathrm{OEP}(17) \mathrm{The}_{2} 5,10,15$-triNO $\mathrm{H}_{2} \mathrm{OEP}$ was made by the Gong and Dolphin method[65]. In an extension of the synthesis of the previous two isomers. After adding around $20 \mathrm{ml}$ of the $0.32 \mathrm{~N} \mathrm{NO}_{2}$ solution, it is left overnight. The reaction mixture is checked via TLC and additional $\mathrm{NO}_{2}$ stock solution is added in increments of 1-2 ml, checking $15-30$ min intervals by TLC until the $\mathrm{Zn} \mathrm{H}_{2} 5,10,15-\mathrm{NO}_{2} \mathrm{OEP}$ is the major product. After separation the product was demetallated using TFA and then washed three times with a saturated solution of $\mathrm{NaHCO}_{3}$. The organic phase was separated, washed with water $(3 \times 400 \mathrm{~mL})$, and taken to dryness on a rotary evaporator and purified by column chromatography as described previously. A ten inch bed of alumina (200-400 mesh) was slurry packed in 2:1 hexane/toluene. The compounds were dissolved in toluene (about 10-15 ml). Decomposition products elute first from the reaction as a 
yellow band. If there were no other compounds formed isomer products were eluted with 1:1 hexane/toluene. $\mathrm{H}_{2} 5,10,15$-triNO ${ }_{2} \mathrm{OEP}$ can metallate on the column during separation, thus after elution of the $\mathrm{H}_{2} 5,10,15-$ triNO$_{2} \mathrm{OEP}$ any compounds at the top of column which do not elute even with pure toluene may be the $\mathrm{Zn} 5,10$, 15-tetraNO $\mathrm{O}_{2} \mathrm{OEP}$. The $\mathrm{Zn} 5,10,15$-triNO $2 \mathrm{OEP}$ will only elute with pure acetone. After the $\mathrm{H}_{2} 5,10,15$ triNO $\mathrm{O}_{2} \mathrm{OEP}$ (50\% yield) was evaporated under vacuum it is recrystallized from 1:1 dichloromethane/hexane and purity checked using UV-Visible spectroscopy and NMR spectroscopy. Compound (17) $\lambda\left(\mathrm{CH}_{2} \mathrm{Cl}_{2}\right)$ soret: 385,405 ; q-bands: $512,540,589,637$; ${ }^{1} \mathrm{HNMR} \delta$ had: $10.08($ meso- $1 \mathrm{H}) ; 3.96\left(\mathrm{~m}, 4 \mathrm{H},-\mathrm{CH}_{2^{-}}\right) ; 3.59\left(\mathrm{~d}, 4 \mathrm{H},-\mathrm{CH}_{2}-\right) ; 3.56(\mathrm{q}, 8 \mathrm{H},-$ $\left.\mathrm{CH}_{2}-\right) ; 1.81\left(\mathrm{t}, 6 \mathrm{H},-\mathrm{CH}_{3}\right) ; 1.55\left(\mathrm{t}, 6 \mathrm{H},-\mathrm{CH}_{3}\right) ; 1.49\left(\mathrm{t}, 6 \mathrm{H},-\mathrm{CH}_{3}\right) ; 1.43\left(\mathrm{t}, 6 \mathrm{H},-\mathrm{CH}_{3}\right) ;-$ 3.4664 (s, 2H, -NH). Anal. Calculated for $\mathrm{C}_{36} \mathrm{H}_{43} \mathrm{~N}_{7} \mathrm{O}_{6}$ : C, 64.56; H, 6.47; N, 14.64 . Found: $\mathrm{C}, 64.37 ; \mathrm{H}, 6.52 ; \mathrm{N}, 14.51$.

$\mathrm{H}_{2} 5,10,15,20$-tetraNO $\mathrm{O}_{2} \mathrm{OEP}(\mathbf{1 8}) \mathrm{The}_{2} 5,10,15,20$-tetra $\mathrm{HO}_{2} \mathrm{OEP}$ was made by the Gong and Dolphin method. Approximately $30 \mathrm{ml}$ stock solution of $0.32 \mathrm{~N} \mathrm{NO}_{2}$ in dichloromethane was added to the ZnOEP solution and left stirring overnight. The next morning the solution was checked using UV-Visible spectroscopy and TLC to ensure the $\mathrm{Zn} 5,10,15,20$-tetraNO${ }_{2} \mathrm{OEP}$ was formed. When the compound was fully nitrated the solution was dark green. The product was demetallated using TFA. The product was washed afterward two to three times with a saturated solution of $\mathrm{NaHCO}_{3}$. The organic phase was separated, washed with water $(3 \times 400 \mathrm{~mL})$, and taken to dryness on a rotary evaporator and purified by column chromatography. A ten inch bed of alumina (200-400 mesh) was slurry packed in toluene. The nitrated products were dissolved in toluene (about $10-15 \mathrm{ml}$ ). The decomposition products from the reaction eluted first with the 
toluene and right after it the $\mathrm{H}_{2} 5,10,15,20$-tetraNO${ }_{2} \mathrm{OEP}$ elutes. This is evaporated under vacuum and recrystallized from 1:1 dichloromethane/hexane. The purity was checked using UV-Visible spectroscopy and NMR spectroscopy. Since the Zn 5, 10, 15, 20-tetraNO $\mathrm{N}_{2} \mathrm{OEP}$ will remetallate on the column some metallated product will remain on the column. This will elute with acetone. The eluent is evaporated and the product is dissolved in methylene chloride. Demetallation is done with TFA and the mixture is washed several times with sodium bicarbonate and right after this several times with deionized water. The product is evaporated under vacuum and it is recrystallized from 1:1 dichloromethane/hexane. The purity is checked using UV-Visible spectroscopy and NMR spectroscopy. Compound (17) $\lambda\left(\mathrm{CH}_{2} \mathrm{Cl}_{2}\right)$ soret: 426; q-bands: 529, 572, 611, 666; ${ }^{1} \mathrm{HNMR} \delta$ had: $3.36\left(\mathrm{~s}, 16 \mathrm{H},-\mathrm{CH}_{2}-\right) ; 1.27\left(\mathrm{t}, 24 \mathrm{H},-\mathrm{CH}_{3}\right) ;-3.0352(\mathrm{~s}, 2 \mathrm{H},-\mathrm{NH})$. $\mathrm{H}_{2}$ 5, 10-diNO ${ }_{2}$ OEP (16) The $\mathrm{H}_{2} 5,10$-diNO ${ }_{2} \mathrm{OEP}$ was made by the Bonnett and Stephenson method. Octaethylporphyrin ( $50 \mathrm{mg}$ ) was shaken with fuming nitric acid (12 $\mathrm{mL})$ at room temperature for $6 \mathrm{~min}$. the solution was poured into iced water $(200 \mathrm{ml})$. The suspension was extracted with methylene chloride, and washed with water several times and then with aqueous sodium bicarbonate and finally with water. The nitrated products (diNO ${ }_{2} \mathrm{OEP}$ and traces of $\mathrm{H}_{2} 5-\mathrm{NO}_{2} \mathrm{OEP}$ ) were taken to dryness in the rotary evaporator and purified by column chromatography. Using the slurry method, a ten inch bed of alumina (200-400 mesh) was packed in 3:1 hexane/toluene. The compounds were dissolved in toluene (about 3-5 ml). The first eluent contains the decomposition products from the reaction as a yellow band. If there are no other compounds formed the isomer products are eluted with $3: 1$ hexane/toluene. By this method the major product of the isomers is the $\mathrm{H}_{2} 5,10$ - $\mathrm{diNO}_{2} \mathrm{OEP}(60 \%$ yield ) and separation through TLC is the same 
as above for the $\mathrm{H}_{2} 5,15-\mathrm{diNO}_{2} \mathrm{OEP}$. The $\mathrm{H}_{2} 5,10-\mathrm{diNO}_{2} \mathrm{OEP}$ is recrystallyzed from 1:1 methylene chloride/hexane and purity checked using UV-Visible spectroscopy and NMR spectroscopy. Compound (16) $\lambda\left(\mathrm{CH}_{2} \mathrm{Cl}_{2}\right)$ soret: 380,396 ; q-bands: $504,538,575,629$; ${ }^{1} \mathrm{HNMR} \delta$ had: $10.10($ meso- $2 \mathrm{H}) ; 4.01\left(\mathrm{~m}, 18 \mathrm{H},-\mathrm{CH}_{2}-\right) ; 3.70\left(\mathrm{q}, 4 \mathrm{H},-\mathrm{CH}_{2^{-}}\right) ; 3.64(\mathrm{q}, 4 \mathrm{H},-$ $\left.\mathrm{CH}_{2-}\right) 1.87\left(\mathrm{~d}, 6 \mathrm{H},-\mathrm{CH}_{3}\right), 1.85\left(\mathrm{~d}, 6 \mathrm{H},-\mathrm{CH}_{3}\right) ; 1.61\left(\mathrm{q}, 6 \mathrm{H},-\mathrm{CH}_{3}\right),-3.9507(\mathrm{~s}, 2 \mathrm{H},-\mathrm{NH})$. The analogs to the above compounds for $\mathrm{H}_{2}$ ETIOI were prepared similarly. These compounds were characterized by UV-Visible spectroscopy and NMR and compared to literature values.

All porphyrins were recrystallized using methylene chloride/methanol solutions or from methylene chloride/hexane first and subsequent recrystallization with methylene chloride/methanol prior to calorimetric or NMR measurements. Purity was ascertained using UV-Vis spectroscopy and NMR spectroscopy. All manipulations prior to calorimetry measurements were carried out in an inert atmosphere glove box (Vacuum Atmospheres) in order to reduce exposure to atmospheric moisture.

\subsection{Thermodynamic studies:}

Thermodynamic studies were carried out using a Setaram C80D isothermal calorimeter with a reversing mechanism. A sample procedure for the determination of a heat of solution follows:

Both the reference cell and sample were cleaned with methylene chloride followed by drying in an oven for at least 60 minutes at $100^{\circ} \mathrm{C}$. After cooling in air, the reference cell was loaded with $3.0 \mathrm{ml}$ of 1, 1,2, 2-tetrachloroethane and $1.0 \mathrm{ml}$ of liquid mercury inside the glove box. The cell was sealed and inverted 10 times to ensure complete mixing. The sample (between 3 and $5 \mathrm{mg}$ ) of porphyrin was placed in the sample cell in the small 
bucket. The small bucket was capped and $1 \mathrm{ml}$ liquid mercury was carefully added to. The top of the cell was loaded with $3.0 \mathrm{ml}$ of 1, 1,2,2-tetrachloroethane. The cells were placed in the calorimeter and the system was allowed to equilibrate for 90 minutes. At this point, the dissolution was initiated using the reversing mechanism at which time an endothermic peak appeared. The dissolution was allowed to proceed to completion. The UV-Vis spectrum was obtained. The measurements were repeated out three times and the value averaged. The enthalpies of protonation were obtained using the same procedure as above, except that the solvent used was $2 \%$ trifluoroacetic acid/1,1,2,2-tetrachloroethane. The calorimetric peak was exothermic. The UV-Vis spectrum of the resulting solution was obtained to monitor the completion of the reaction.

\subsection{Competition studies:}

To a $10 \mathrm{ml}$ flask stoichiometric amount of $\mathrm{H}_{2} \mathrm{TPP}$, a second free-base porphyrin and 2 equivalents of trifluoroacetic acid were added. The flask was diluted to mark with the methylene chloride. Spectra of the mixture were taken. By spectral comparison, the relative basicity of each porphyrin was qualitatively determined and compared to the results from the calorimetric studies.

\subsection{NMR studies}

\subsection{1 ${ }^{1} \mathrm{H}$ NMR of free-base porphyrins}

Proton NMR spectra were recorded on a $400 \mathrm{MHz}$. The spectra of free-bases were measured in $\mathrm{CDCl}_{3}$ solution, and the protonated species were obtained by addition of $c a$ 200 equivalents of TFA to these solutions. In all cases the solvent peak ( $7.26 \mathrm{ppm})$ was used as an internal standard 
Variable-temperature proton NMR spectroscopy was used to study the NH tautomerization in solution of $\mathrm{H}_{2} 5-\mathrm{NO}_{2} \mathrm{OEP}(14), \mathrm{H}_{2} 5-\mathrm{NO}_{2}$ ETIOI (19), $\mathrm{H}_{2} 5,10,15$ triNO ${ }_{2} \mathrm{OEP}(\mathbf{1 7})$, and $\mathrm{H}_{2} 5,10,15,20$-tetraNO $\mathrm{O}_{2} \mathrm{OEP}(\mathbf{1 8})$. The rate of interconversion of the two porphyrin tautomers (A and B) is determined by the free energy of activation $\left(\Delta G^{\ddagger}\right)$. If the rate of interconversion is slow (on the NMR time scale), then will observe the NMR spectra of the two separate signals of the two separate species. The position where the two separate peaks just merge into one is called the coalescence point. At this point the lifetime of any of the tautomers is given by:

$\tau=\sqrt{ } 2 / \pi \delta_{\mathrm{v}} \mathrm{s}$, where $\delta_{\mathrm{v}}=v_{\mathrm{A}}-v_{\mathrm{B}}$

The free energy of activation from the coalescence temperature $\left(T_{c}\right)$ is:

$\underline{\Delta \mathrm{G}^{*}}=22.96+\log _{\mathrm{e}}\left(\mathrm{T}_{\mathrm{d}} / \delta_{\mathrm{v}}\right)$

$\mathrm{R} \mathrm{T}_{\mathrm{c}}$ 
5.5 Theoretical calculations All molecular modeling studies were carried out using the Hyperchem $®$ program module. Each structure was optimized using molecular mechanics using the $\mathrm{MM}+$ force field. This minimized structure was then submitted to minimization using the semiempirical methods using the PM3 basis set.

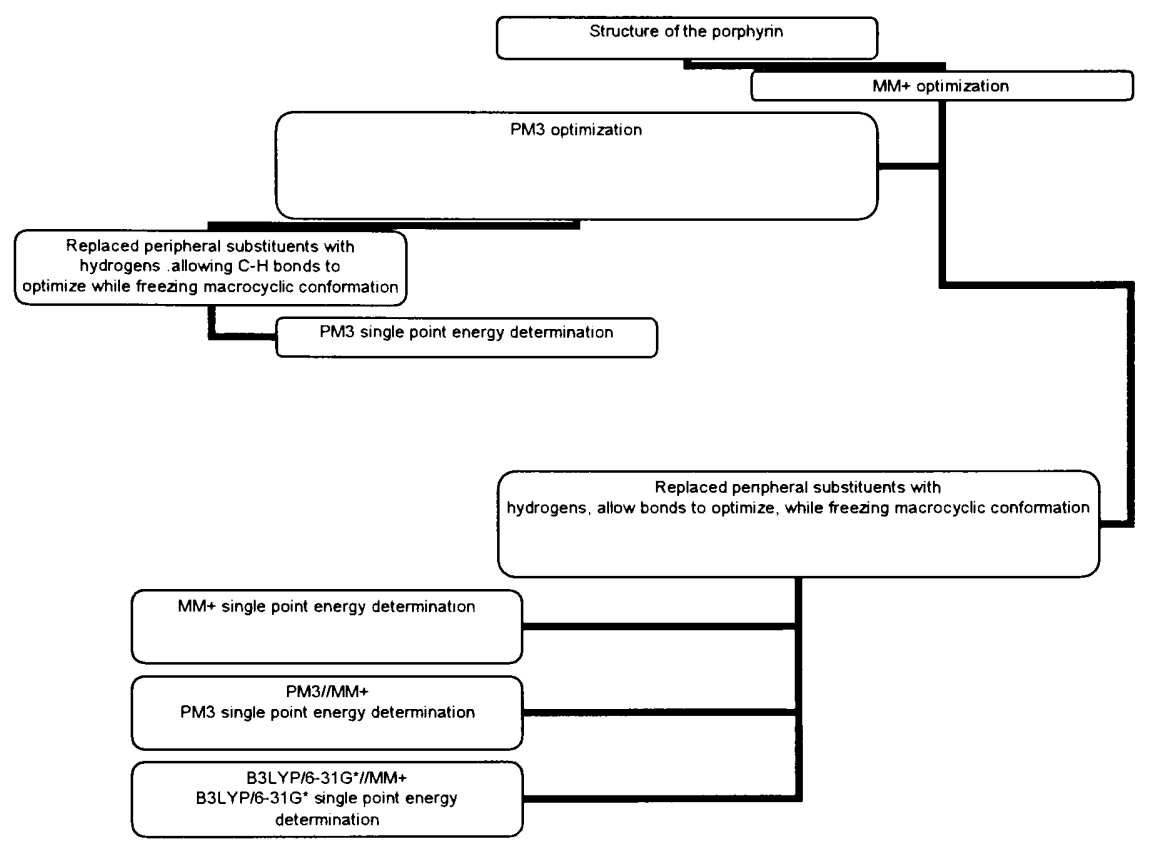

Figure 9. Theoretical calculations flowchart.

In both the PM3 minimized structures and the $\mathrm{MM}+$ minimized structures, the peripheral substituents of each of the porphyrins were removed and substituted by hydrogen atoms. The macrocyclic conformation was not allowed to change but the $\mathrm{C}-\mathrm{H}$ 
bonds just created were allowed to relax. Single point energy calculations of the macrocycle frozen in that conformation were carried out. The single point energy determinations were carried out using $\mathrm{MM}+$, PM3 and a hybrid method using density functional theory (B3LYP/6-31G*).

Calculation times for molecular mechanics and semiempirical minimizations ranged from 10 minutes to 2 hours depending on the number of atoms in the porphyrin. The longest calculations involved the single point energy determinations using density functional B3LYP/6-31G* method. Calculation times ranged from 24 hours to 5 days. Calculations were done using a Dell Inspiron I8200 with Intel® Pentium ${ }^{8} 4$, $1.70 \mathrm{GHz}$ and $256 \mathrm{MB}$ of RAM. 


\section{Results and Discussion}

\subsection{Calorimetric Studies}

The enthalpies of solution (equation 6-1) in TCE and the enthalpies of protonation using TFA/TCE (equation 6-2) of nine solid free-base porphyrins were determined and are reported in Table 2. These values were used in order to determine the enthalpies of protonation in solution for each of the free-base porphyrins as is shown for octaethylporphyrin ( $\left.\mathrm{H}_{2} \mathrm{OEP}\right)$ (equation 6-3 and 6-4).

\begin{tabular}{cl}
$\mathrm{H}_{2} \mathrm{OEP}_{\text {(solid) }}+\mathrm{TCE} \rightarrow \mathrm{H}_{2} \mathrm{OEP}_{\text {(soln) }}$ & $\Delta \mathrm{H}_{\text {soln (H2OEP) }}$ \\
$\frac{\mathrm{H}_{2} \mathrm{OEP}_{\text {(solid) }}+2 \mathrm{HO}_{2} \mathrm{C}_{2} \mathrm{~F}_{3} / \mathrm{TCE} \rightarrow \mathrm{H}_{4} \mathrm{OEP}_{\text {(soln) }}^{+2}+2 \mathrm{O}_{2} \mathrm{C}_{2} \mathrm{~F}_{3}^{-} \text {(sol'n) }}{\Delta \mathrm{H}_{\text {prot (solid) (H2OEP) }}}$ & $\Delta \mathrm{H}_{\text {(prot in soln) (H2OEP) }}$ \\
\cline { 1 - 1 } $\mathrm{H}_{2} \mathrm{OEP}_{\text {(soln) }}+2 \mathrm{HO}_{2} \mathrm{C}_{2} \mathrm{~F}_{3} / \mathrm{TCE} \rightarrow \mathrm{H}_{4} \mathrm{OEP}_{\text {(soln) }}^{+2}+2 \mathrm{O}_{2} \mathrm{C}_{2} \mathrm{~F}_{3}^{-}$ & \\
$\Delta \mathbf{H}_{\text {prot. in soln (OEP) }}=\Delta \mathbf{H}_{\text {prot solid (OEP) }}-\Delta \mathbf{H}_{\text {soln (OEP) }}$ & \\
$\mathrm{H}_{4} \mathrm{P}_{\text {(soln) }}^{+2}+\mathrm{H}_{2} \mathrm{OEP}_{\text {(soln) }} \rightarrow \mathrm{H}_{4} \mathrm{OEP}_{\text {(soln) }}^{+2}+\mathrm{H}_{2} \mathrm{P}_{\text {(soln) }}$ & $\Delta \mathrm{H}_{\text {proton trans. }}$ \\
$\Delta \mathbf{H}_{\text {proton trans }}=\Delta \mathbf{H}_{\text {(prot in soln) (H2OEP) }}-\Delta \mathbf{H}_{\text {prot in soln (H2P) }}$
\end{tabular}

The enthalpy of transfer of two protons from $\mathrm{H}_{4} \mathrm{OEP}^{+2}$ to any other free-base porphyrin is obtained by subtracting the enthalpy of protonation of $\mathrm{H}_{2} \mathrm{OEP}$ from the enthalpy of protonation of each of the other free-base porphyrins (see Table 2). This is a direct measure of the basicity of $\mathrm{H}_{2} \mathrm{OEP}$ versus those of the other free-base porphyrins, the larger the $\Delta \mathrm{H}_{\text {proton trans. }}$ the more basic the free-base porphyrin. These results are also reported in Table 2 
Table 2. Enthalpies ${ }^{\mathrm{a}}$ of solution and protonation in solution of different synthetic symmetrical porphyrins in 1, 1, 2, 2-tetrachloroethane (TCE).

\begin{tabular}{|c|c|c|c|c|}
\hline free-base porphyrin & $\Delta H_{\text {soln }}{ }^{b}$ & $\Delta H_{\text {prot solid }}{ }^{c}$ & $\Delta \mathrm{H}_{\text {prot in soln }}{ }^{\mathrm{d}}$ & $\Delta \mathrm{H}_{\text {prot transfer }}{ }^{\mathrm{e}}$ \\
\hline $\mathrm{H}_{2} \mathrm{OEP}$ & $+8.1 \pm 0.05$ & $-36.4 \pm 1.04$ & $-44.5 \pm 1.6$ & 0 \\
\hline $\mathrm{H}_{2}$ ETIOI & $+3.50 \pm 0.2$ & $-43.7 \pm .95$ & $-47.3 \pm 1.0$ & -2.8 \\
\hline $\mathrm{H}_{2} \mathrm{OIP}$ & $+5.68 \pm 0.18$ & $-37.4 \pm 0.78$ & $-43.0 \pm 0.8$ & 1.5 \\
\hline $\mathrm{H}_{2} \mathrm{TPP}$ & $+1.95 \pm 0.07$ & $-43.3 \pm 0.18$ & $-45.3 \pm 0.2$ & -0.8 \\
\hline $\mathrm{H}_{2} \mathrm{~T}\left(\mathrm{C}_{6} \mathrm{~F}_{5}\right) \mathrm{P}$ & 0 & $-26.82 \pm 0.42$ & $-26.82 \pm 0.42$ & 17.7 \\
\hline $\mathrm{H}_{2} \mathrm{~T}(\mathrm{nPe}) \mathrm{P}$ & $+6.3 \pm 0.17$ & $-38.9 \pm 0.34$ & $-45.1 \pm 0.4$ & -0.6 \\
\hline $\mathrm{H}_{2} \mathrm{~T}(\mathrm{iPr}) \mathrm{P}$ & $+1.33 \pm 0.34$ & $-43.43 \pm 0.46$ & $-45.23 \pm 0.6$ & -0.7 \\
\hline $\mathrm{H}_{2} \mathrm{~T}(\mathrm{tBu}) \mathrm{P}$ & 0 & $-52.0 \pm 0.6$ & $-52.0 \pm 0.6$ & -7.5 \\
\hline $\mathrm{H}_{2}$ tetraNO $\mathrm{NO}_{2} \mathrm{OEP}$ & $+1.36 \pm 0.16$ & $-26.22 \pm 0.30$ & $-27.6 \pm 0.34$ & 16.9 \\
\hline $\mathrm{H}_{2} \mathrm{OETPP}$ & $(+1.4)$ & $-69.6 \pm 1.8$ & -68.9 & -26.4 \\
\hline \multicolumn{5}{|c|}{$\begin{array}{l}{ }^{\mathrm{b}} \Delta \mathrm{H} \text { of dissolution of the solid free-base porphyrin } \\
\qquad \mathrm{H}_{2} \mathrm{P} \text { (solid) }+\mathrm{C}_{2} \mathrm{Cl}_{4} \mathrm{H}_{2} \text { (liquid) } \rightarrow \mathrm{H}_{2} \mathrm{P} \text { (soln) }\end{array}$} \\
\hline \multicolumn{5}{|c|}{$\begin{array}{l}{ }^{c} \Delta \mathrm{H} \text { of the dissolution and protonation of the solid free-base porphyrin } \\
\left.\left.\qquad \mathrm{H}_{2} \mathrm{P}(\text { solid })+2 \mathrm{HO}_{2} \mathrm{C}_{2} \mathrm{~F}_{3} \text { (soln }\right) \rightarrow \mathrm{H}_{4} \mathrm{P}^{+2} \text { (soln }\right)+2 \mathrm{O}_{2} \mathrm{C}_{2} \mathrm{~F}_{3}^{-1} \text { (soln) }\end{array}$} \\
\hline \multicolumn{5}{|c|}{$\begin{array}{l}{ }^{\mathrm{d}} \Delta \mathrm{H} \text { of protonation of the dissolved free-base porphyrin } \\
\qquad \mathrm{H}_{2} \mathrm{P}(\text { soln })+2 \mathrm{HO}_{2} \mathrm{C}_{2} \mathrm{~F}_{3}(\text { soln }) \rightarrow \mathrm{H}_{4} \mathrm{P}^{+2} \text { (soln) }+2 \mathrm{O}_{2} \mathrm{C}_{2} \mathrm{~F}_{3}{ }^{-1}\end{array}$} \\
\hline \multicolumn{5}{|c|}{$\begin{array}{l}{ }^{\mathrm{e}} \Delta \mathrm{H} \text { of two proton transfer from each of the porphyrin dications to } \mathrm{H}_{2} \mathrm{OEP} \text { in solution } \\
\qquad \mathrm{H}_{4} \mathrm{OEP}^{+2}(\text { soln })+\mathrm{H}_{2} \mathrm{P}(\text { soln }) \rightarrow \mathrm{H}_{4} \mathrm{P}^{+2}(\text { soln })+\mathrm{H}_{2} \mathrm{OEP}(\text { soln })\end{array}$} \\
\hline
\end{tabular}




\subsubsection{Enthalpies of solution}

The enthalpies of solution of several porphyrin free-bases in TCE vary significantly (see Table 2). Porphine and octamethylporphyrin are essentially insoluble in TCE. Their $\Delta \mathrm{H}_{\text {solution }}$ cannot be measured calorimetrically. Having only hydrogens or other small groups in the periphery allows the macrocycle to remain planar and the rings to stack upon each other very tightly causing their insolubility. Peripheral substituents do not allow efficient stacking and lower the barrier towards dissolution. For $\mathrm{H}_{2} \mathrm{OEP}$ (5) and $\mathrm{H}_{2} \mathrm{OIP}$ (7), the enthalpies of solution are 8.1 and $5.7 \mathrm{kcal} / \mathrm{mole}$, respectively. For symmetrically substituted octaalkylporphyrins the enthalpy of solution decreases with the increasing bulkiness of the $\beta$-substituent. $[67,68]$

In tetra meso substituted porphyrins, the substituents serve to keep the porphyrins apart, resulting in even smaller solution enthalpies. The phenyl groups in $\mathrm{H}_{2}$ TPP (8) and the pentafluorophenyl groups in $\mathrm{H}_{2} \mathrm{~T}\left(\mathrm{C}_{6} \mathrm{~F}_{5}\right) \mathrm{P}$ (12) are not coplanar with the porphyrin ring preventing the macrocycles from properly stacking on top of each other. $\mathrm{H}_{2} \mathrm{TPP}$ has a very low $\Delta \mathrm{H}_{\text {soln }}$ of $+1.36 \mathrm{kcal} / \mathrm{mole}$, and $\mathrm{H}_{2} \mathrm{~T}\left(\mathrm{C}_{6} \mathrm{~F}_{5}\right) \mathrm{P}$ has a $\Delta \mathrm{H}_{\text {soln }}$ so small that it could not be measured. The other tetrasubstituted porphyrin which is believed to be planar is the $\mathrm{H}_{2} \mathrm{~T}(\mathrm{nPe}) \mathrm{P}(9)$. The n-pentyl group is less bulky and all indications are that this is a planar molecule. Additionally, it is flexible enough to allow efficient $\pi$-stacking. This compound has the highest heat of solution of all of the tetrasubstituted porphyrins $\left(\Delta \mathrm{H}_{\text {soln }}\right.$ $=6.3 \mathrm{kcal} / \mathrm{mole})$. Once steric interactions are increased by placing bulkier groups at the meso positions the macrocycle begins to ruffle. Since the macrocycle is no longer planar, $\pi$-stacking is reduced and the heat of solution is small. The $\Delta \mathrm{H}_{\text {soln }}$ of $\mathrm{H}_{2} \mathrm{~T}(\mathrm{nPe}) \mathrm{P}(9)$, $\mathrm{H}_{2} \mathrm{~T}(\mathrm{iPr}) \mathrm{P}(10)$ and $\mathrm{H}_{2} \mathrm{~T}(\mathrm{tBu}) \mathrm{P}(11)$ are $6.3,1.3$ and $0 \mathrm{kcal} /$ mole, respectively. This series 
demonstrates that the greater the ruffling of the molecule, the smaller the $\Delta \mathrm{H}_{\text {soln }}$ and the greater the solubility of the porphyrin.

$\mathrm{H}_{2} 5,10,15,20$-tetra $\mathrm{NO}_{2} \mathrm{OEP}(18)$, which shows a saddled structure, also displays a very small heat of solution. This can again be assumed to be taking place due to its nonplanar structure. The heat of solution of $\mathrm{H}_{2} \mathrm{OETPP}$ (13) could not be measured since it protonates even with minute traces of moisture. We believe the $\Delta H_{\text {solution }}$ is somewhere between 0 and $1.4 \mathrm{kcal} /$ mole since we expect it to be similar to the other dodecasubstituted porphyrins in the study. We have included this value in the reported enthalpies but have assigned to it a larger uncertainty.

\subsubsection{Energetics of two proton transfer}

When a free-base porphyrin is protonated the steric congestion due to the presence of four hydrogens in the core causes the saddled conformation to result. $[69,70]$ Although the dications in general have a saddle type conformation, studies have shown that these are flexible and the degree of saddling will vary among the different dications. [71, 72] In the diacid, no intramolecular hydrogen bonding will take place. Additionally, since the structures are distorted, $\pi$ orbital overlap will be compromised although $\pi$ overlap between the meso substituents and the macrocycle may be enhanced.

$\mathrm{H}_{2} \mathrm{~T}\left(\mathrm{nC}_{5} \mathrm{~F}_{5}\right) \mathrm{P}$ is much less basic than the other two and is the least basic of the freebase studied. This must be due to the electron withdrawing effects of the pentafluorophenyl group $(\sigma=0.26)$. Since the pentafluorophenyl group is not coplanar with the macrocycle in the free-base system, the electron withdrawing effects must due largely to inductive rather than resonance effects. However upon protonation to form the dication, less of an energy barrier towards aryl rotation exists, [73] better $\pi$ orbital overlap 
may exist between the pentafluorophenyl group and the macrocycle. The pyrrole hydrogen positions now feel more of the effects of the pentafluorophenyl group thereby destabilizing the diacid relative to the free-base.

Interestingly, one of the least and the most basic of the free-bases are both dodecasubstituted porphyrins. $\mathrm{H}_{2} \mathrm{OETPP}(13)$ is the most basic having a $\Delta \mathrm{H}_{\text {prot trans }}$ of $26.4 \mathrm{kcal} / \mathrm{mole}$. Hammett $\sigma$ parameters indicate that there exist only small differences in electronic effects. The reason is so basic must be due to the instability of the saddled conformation. The magnitude of this value is not surprising since $\mathrm{H}_{2}$ OETPP (13) is able to deprotonate water. $\mathrm{H}_{2} 5,10,15,20$-tetraNO $\mathrm{NO}_{2} \mathrm{OEP}(18)$ is one of the least basic having a $\Delta \mathrm{H}_{\text {prot trans }}$ of $+16.9 \mathrm{kcal} / \mathrm{mole}$. Clearly this is due mainly to the electronic effects of the four $\mathrm{NO}_{2}$ groups. Again in the free-base the $\mathrm{NO}_{2}$ groups are not coplanar with the macrocycle, and only inductive effects can affect the macrocycle $\pi$-system. However, a greater degree of planarity may be occurring in the diacid, making the resonance effects more significant and causing the diacid to be more easily deprotonated due to the electron withdrawing nature of the $\mathrm{NO}_{2}$ group.

Enthalpies of two proton transfer from $\mathrm{H}_{4} \mathrm{OEP}^{+2}$ to another porphyrin are given in Table $3\left(\Delta \mathrm{H}_{\text {prot trans }}\right)$. This is a direct measure of the basicity of the different free-bases: the more negative the value, the greater the basicity. We find in Table 3 that the $\Delta \mathrm{H}_{\text {prottransfer }}$ increases in the following order:

$\mathrm{H}_{2} \mathrm{~T}\left(\mathrm{C}_{6} \mathrm{~F}_{5}\right) \mathrm{P} \cong \mathrm{H}_{2} 5,10,15,20$-tetraNO ${ }_{2} \mathrm{OEP}<<\mathrm{H}_{2} \mathrm{OIP}<\mathrm{H}_{2} \mathrm{OEP} \cong \mathrm{H}_{2} \mathrm{~T}(\mathrm{nPe}) \mathrm{P} \cong$ $\mathrm{H}_{2} \mathrm{~T}(\mathrm{iPr}) \mathrm{P} \cong \mathrm{H}_{2} \mathrm{TPP}<\mathrm{H}_{2}$ ETIOI $<\mathrm{H}_{2} \mathrm{~T}(\mathrm{tBu}) \mathrm{P}<<\mathrm{H}_{2}$ OETPP 
Table 3. Enthalpy of two proton transfer, macrocyclic conformation and Hammett's $\sigma$ parameter for $R_{1}$ and $R_{2}$ substituents.

\begin{tabular}{|c|c|c|c|}
\hline free-base & $\underset{\substack{\Delta \mathrm{H}_{\mathrm{p}}{ }_{\mathrm{a}} \\
\text { transfer }}}{\mathrm{a}}$ & conformation $^{b}$ & $\sigma_{\mathrm{m}}\left(\mathrm{R}_{1}\right), \sigma_{\mathrm{m}}\left(\mathrm{R}_{2}\right)^{\mathrm{c}}$ \\
\hline $\mathrm{H}_{2} \mathrm{OEP}(5)$ & 0 & Planar & $-0.07,0$ \\
\hline $\mathrm{H}_{2}$ ETIOI (6) & -2.8 & Planar & $-0.07,0$ \\
\hline $\mathrm{H}_{2} \mathrm{O}(\mathrm{iPr}) \mathrm{P}(7)$ & 1.5 & Planar & $-0.04,0$ \\
\hline $\mathrm{H}_{2} \mathrm{TPP}(8)$ & -0.8 & Planar & $0,0.6$ \\
\hline $\mathrm{H}_{2} \mathrm{~T}(\mathrm{nPe}) \mathrm{P}(9)$ & -0.6 & Planar & $0,-0.05$ \\
\hline $\mathrm{H}_{2} \mathrm{~T}(\mathrm{iPr}) \mathrm{P}(10)$ & -0.7 & Ruffled & $0,-0.04$ \\
\hline $\mathrm{H}_{2} \mathrm{~T}(\mathrm{tBu}) \mathrm{P}(11)$ & -7.5 & Ruffled & $0,-0.10$ \\
\hline $\mathrm{H}_{2} \mathrm{OETPP}(13)$ & -26.4 & Saddled & $-0.07,0.06$ \\
\hline $\mathrm{H}_{2} \mathrm{~T}\left(\mathrm{nC}_{5} \mathrm{~F}_{5}\right) \mathrm{P}(12)$ & 17.7 & Planar & $0,0.26$ \\
\hline $\mathrm{H}_{2} 5,10,15,20-\mathrm{NO}_{2} \mathrm{OEP}(18)$ & 16.9 & Saddled & $-0.07,0.71$ \\
\hline \multicolumn{4}{|c|}{$\begin{array}{l}{ }^{\mathrm{a}} \Delta \mathrm{H} \text { of two proton transfer from each of the porphyrin dications to } \mathrm{H}_{2} \mathrm{OEP} \text { in } \\
\text { solution. }\end{array}$} \\
\hline \multicolumn{4}{|c|}{$\mathrm{H}_{4} \mathrm{P}^{+2}($ soln $)+\mathrm{H}_{2} \mathrm{OEP}($ soln $) \rightarrow \mathrm{H}_{4} \mathrm{OEP}^{+2}($ soln $)+\mathrm{H}_{2} \mathrm{P}($ soln $)$} \\
\hline \multicolumn{4}{|c|}{$\begin{array}{l}\text { b Conformation of the free-base macrocycle as predicted by molecular } \\
\text { mechanics calculations and X-ray crystal structures available. }\end{array}$} \\
\hline \multicolumn{4}{|c|}{${ }^{\mathrm{c}}$ Hammett's $\sigma_{\mathrm{m}}$ parameters for $\mathrm{R}_{1}$ and $\mathrm{R}_{2}$} \\
\hline
\end{tabular}




\subsubsection{Competition studies}

In order to verify this order competition studies were carried out, as described in the experimental section. In Figure 10 are shown three different spectra, the free-base $\mathrm{H}_{2} \mathrm{OEP}$, the dication $\mathrm{H}_{4} \mathrm{OEP}^{+2}$ and the monocation $\mathrm{H}_{3} \mathrm{OEP}^{+1}$. The monocation is easily seen in solution but difficult to isolate since upon crystallization a type of disproportionation reaction seems to take place, where the dication is formed at the expense of the monocation. In each experiment an equimolar solution of two free-bases was made. In order to be able to distinguish more easily, one of the free-bases was always $\mathrm{H}_{2} \mathrm{TPP}(8)$, since it has a large absorption for the dication at $650 \mathrm{~nm}$. To this solution was added approximately 2 equivalents of trifluoroacetic acid. Spectra were obtained. Some of these are shown in Figures 11-13. In Figure 11 the spectra of the mixture can be accounted by addition of the spectra of the dication of $\mathrm{H}_{2} \mathrm{TPP}$, a small amount of $\mathrm{H}_{2}$ TPP and the free base $\mathrm{H}_{2} 5,10,15,20$-tetraNO $\mathrm{N}_{2} \mathrm{OEP}$ (18). No dication of the $\mathrm{H}_{2} 5,10,15,20$-tetraNO${ }_{2} \mathrm{OEP}$ (18) was formed, verifying the greater basicity of the $\mathrm{H}_{2}$ TPP (8). In Figure 12 a similar study was carried out between $\mathrm{H}_{2} \mathrm{OEP}$ (7) and $\mathrm{H}_{2} \mathrm{TPP}(8)$. By adjusting the ratios of dications and free-bases we concluded that the $\mathrm{H}_{2}$ TPP (8) was again preferentially protonated and hence more basic than the $\mathrm{H}_{2} \mathrm{OEP}$ (5) (Figure 12). This again verified their relative positions in the calorimetric studies. A similar study was carried out with $\mathrm{H}_{2} \mathrm{OIP}$ (7) competing with $\mathrm{H}_{2}$ TPP (8) and the dication of $\mathrm{H}_{2}$ TPP (8) was formed with the monocation of $\mathrm{H}_{2} \mathrm{OIP}$. Additional studies were carried out by dissolving the free-bases in pure acetic acid. For $\mathrm{H}_{2} \mathrm{OEP}$ the monocation was almost exclusively obtained. For $\mathrm{H}_{2}$ TPP the dication was obtained. For $\mathrm{H}_{2} \mathrm{~T}(\mathrm{iPr}) \mathrm{P}$ the dication 
was obtained. This showed that the $\mathrm{H}_{2} \mathrm{~T}(\mathrm{iPr}) \mathrm{P}$ was more basic than $\mathrm{H}_{2} \mathrm{OEP}$. We were able, in this manner to verify the relative positions generated by the calorimetric studies.

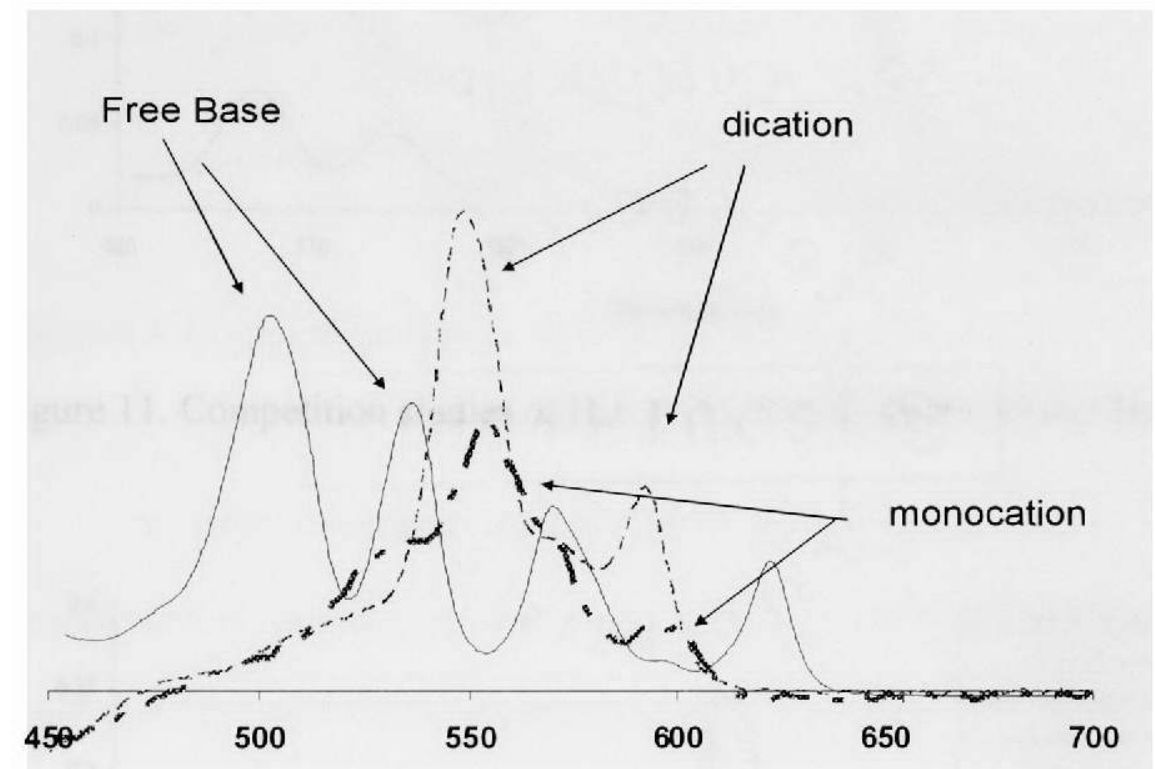

Figure 10. UV-Vis spectra of $\mathrm{H}_{2} \mathrm{OEP}(5), \mathrm{H}_{3} \mathrm{OEP}{ }^{1+}$, and $\mathrm{H}_{4} \mathrm{OEP}^{2+}$. 


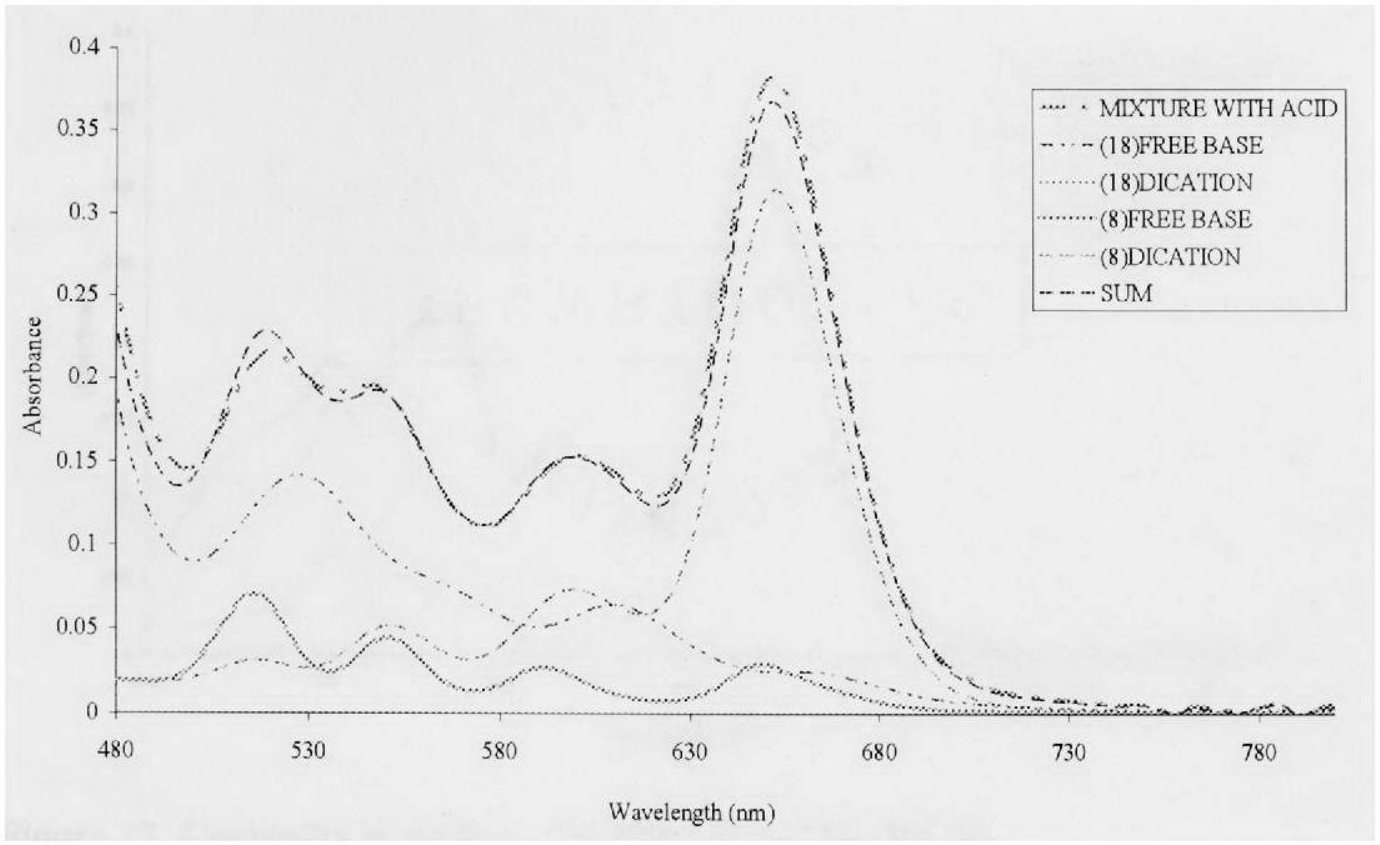

Figure 11. Competition studies of $\mathrm{H}_{2} 5,10,15,20-\mathrm{NO}_{2} \mathrm{OEP}$ (18) and $\mathrm{H}_{2} \mathrm{TPP}$ (8).

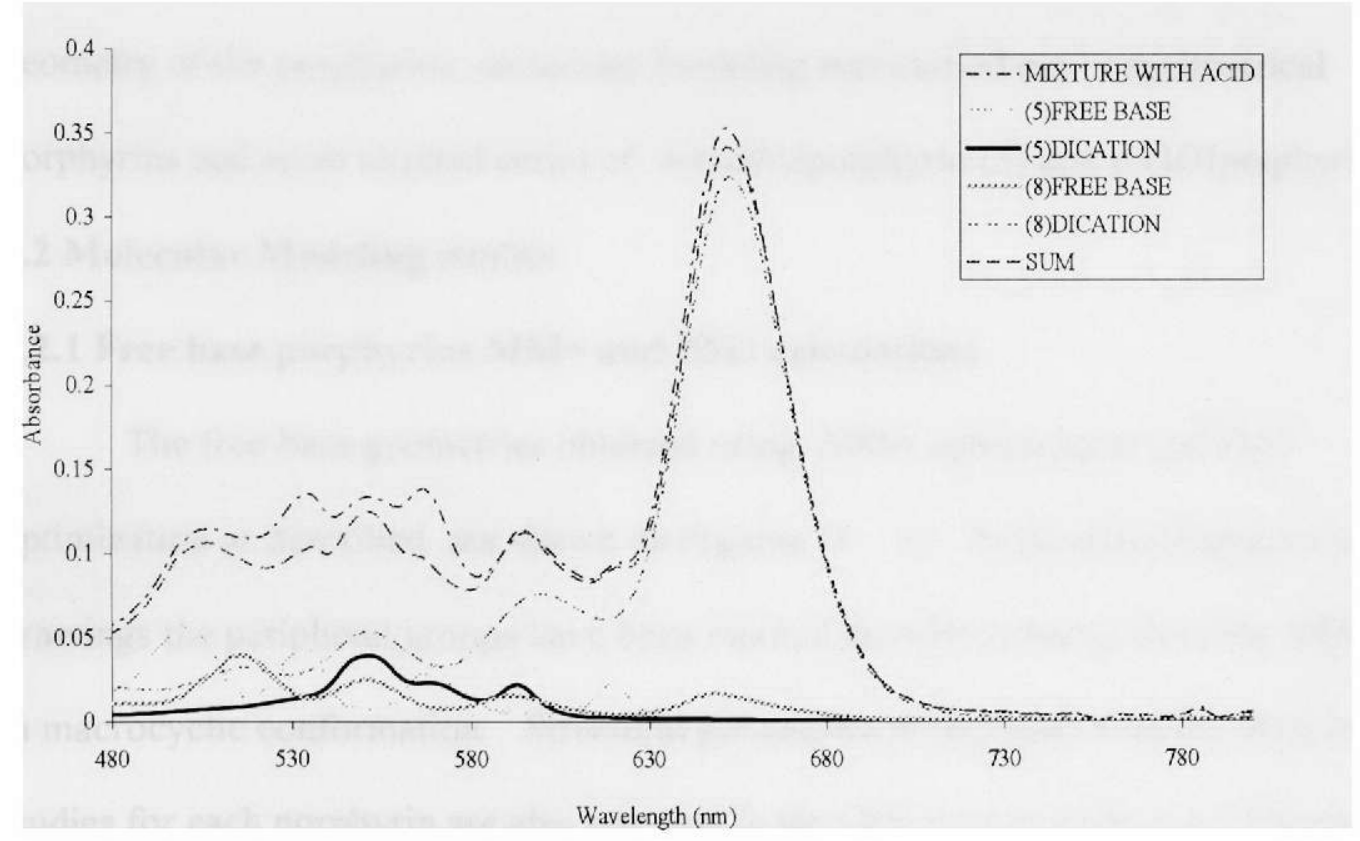

Figure 12. Competition studies of $\mathrm{H}_{2} \mathrm{OEP}(5)$ and $\mathrm{H}_{2} \mathrm{TPP}$ (8). 


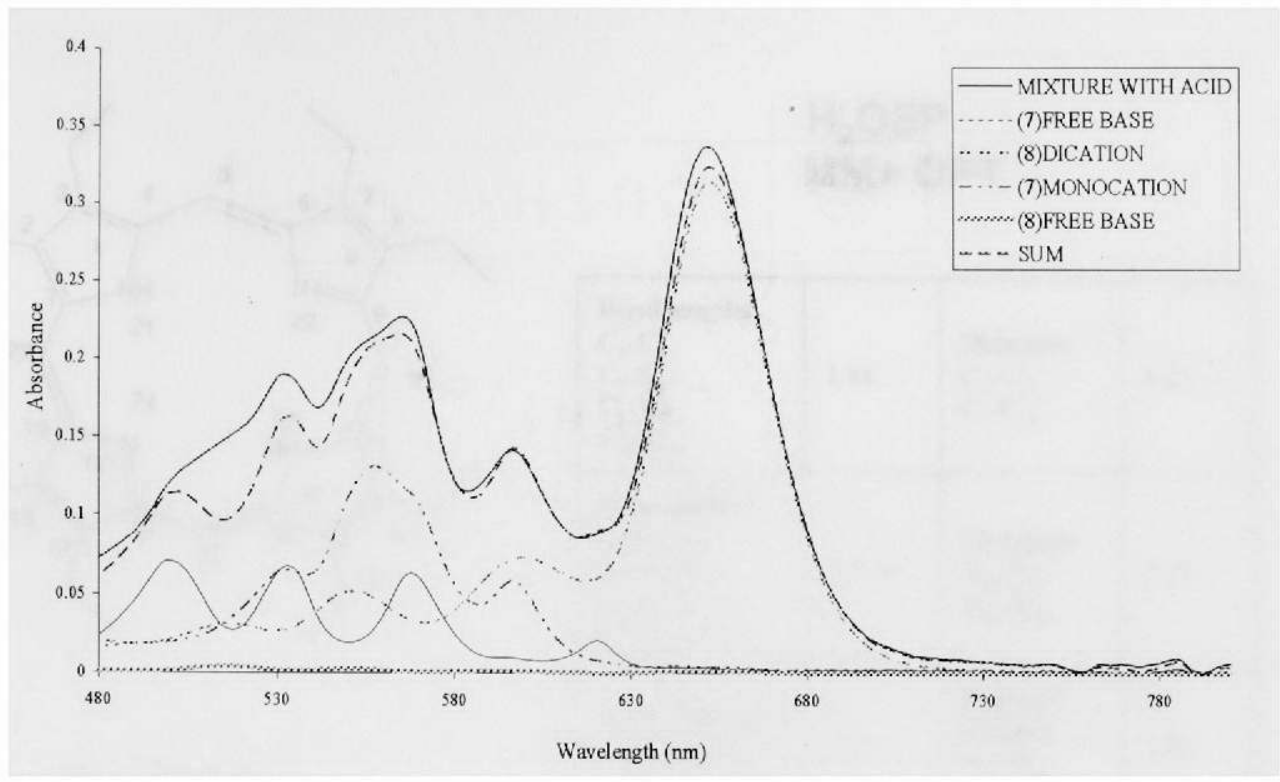

Figure 13. Competition studies of $\mathrm{H}_{2} \mathrm{OIP}(7)$ and $\mathrm{H}_{2} \mathrm{TPP}$ (8).

In order to correlate thermodynamic studies to the energetic of a particular geometry of the porphyrins, molecular modeling was carried out in symmetrical porphyrins and meso nitrated series of octaethylporphyrin (5) and ETIOIporphyrin (6).

\subsection{Molecular Modeling studies}

\subsubsection{Free base porphyrins MM+ and PM3 calculations}

The free-base geometries obtained using $\mathrm{MM}+$ optimization and PM3 optimization as described are shown on Figures $15-33$. In the three dimensional drawings the peripheral groups have been omitted in order to better show the differences in macrocyclic conformation. Structural parameters determined from the modeling studies for each porphyrin are also reported in the table next to each of the Figures. In Tables 4-22 the significance of each of the parameters are shown. 

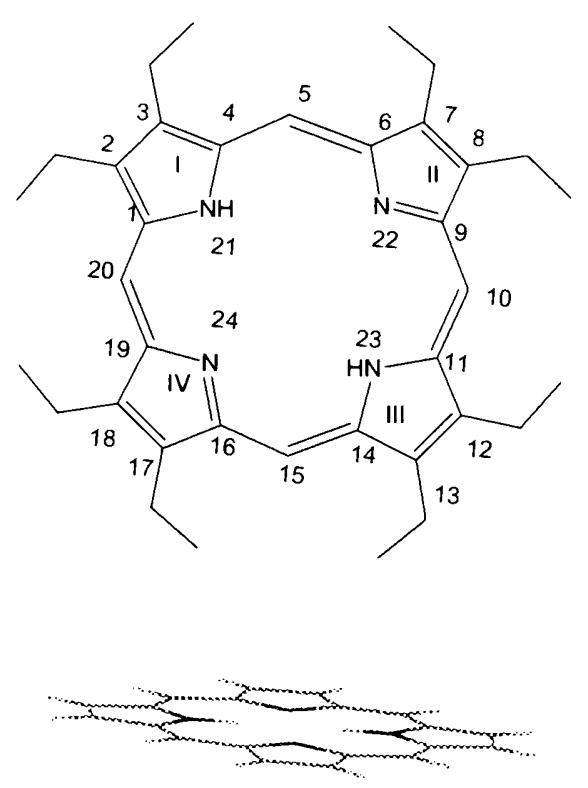

Free base $-\mathrm{MM}+\mathrm{OPT}$

a

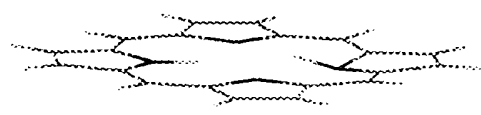

Free base - PM3 OPT

b

Figure 14. Optimized structures of $\mathrm{H}_{2}$ OEP using $\mathrm{MM}+(\mathrm{a})$ and PM3(b) calculations. Peripheral substituents have been replaced by hydrogens.

\section{$\mathrm{H}_{2}$ OEP \\ $\mathrm{MM}+$ OPT}

\begin{tabular}{|c|c|c|c|}
\hline $\begin{array}{l}\text { Bond lengths } \\
\mathrm{C}_{2}-\mathrm{C}_{3} \\
\mathrm{C}_{7}-\mathrm{C}_{8} \\
\mathrm{C}_{12}-\mathrm{C}_{13} \\
\mathrm{C}_{17}-\mathrm{C}_{18} \\
\end{array}$ & 1.34 & $\begin{array}{l}\text { Distances } \\
C_{3}-C_{12} \\
C_{7}-C_{18}\end{array}$ & 8.12 \\
\hline $\begin{array}{l}\text { Meso angles } \\
C_{4}-C_{5}-C_{6} \\
C_{9}-C_{10}-C_{11} \\
C_{14}-C_{15}-C_{16} \\
C_{19}-C_{20}-C_{1}\end{array}$ & 127.46 & $\begin{array}{l}\text { Distances } \\
\mathrm{N}_{21}-\mathrm{N}_{23} \\
\mathrm{~N}_{22}-\mathrm{N}_{24}\end{array}$ & 3.97 \\
\hline $\begin{array}{l}\text { Tors. angle (rf) } \\
C_{2}-C_{3}-C_{12}-C_{13} \\
C_{7}-C_{8}-C_{17}-C_{18}\end{array}$ & 1.67 & $\begin{array}{l}\text { Distance } \\
\text { shortest } \\
\mathrm{N}_{21}-\mathrm{N}_{22} \\
\mathrm{~N}_{23}-\mathrm{N}_{24} \\
\end{array}$ & 2.81 \\
\hline $\begin{array}{l}\text { Tors. angle(sd) } \\
\mathrm{C}_{1}-\mathrm{N}_{21}-\mathrm{C}_{4}-\mathrm{C}_{5} \\
\mathrm{C}_{6}-\mathrm{N}_{22}-\mathrm{C}_{9}-\mathrm{C}_{10} \\
\mathrm{C}_{11}-\mathrm{N}_{23}-\mathbf{C}_{14}-\mathrm{C}_{15} \\
\mathrm{C}_{16}-\mathrm{N}_{24}-\mathrm{C}_{19}-\mathrm{C}_{20}\end{array}$ & 0.50 & $\begin{array}{l}\text { Distance } \\
\text { largest } \\
\mathrm{N}_{21}-\mathrm{N}_{24} \\
\mathrm{~N}_{22}-\mathrm{N}_{23}\end{array}$ & 2.81 \\
\hline
\end{tabular}

Table 4. Bond lengths, angles and distances obtained from the $\mathrm{MM}+$ optimized structure of $\mathrm{H}_{2} \mathrm{OEP}$. 


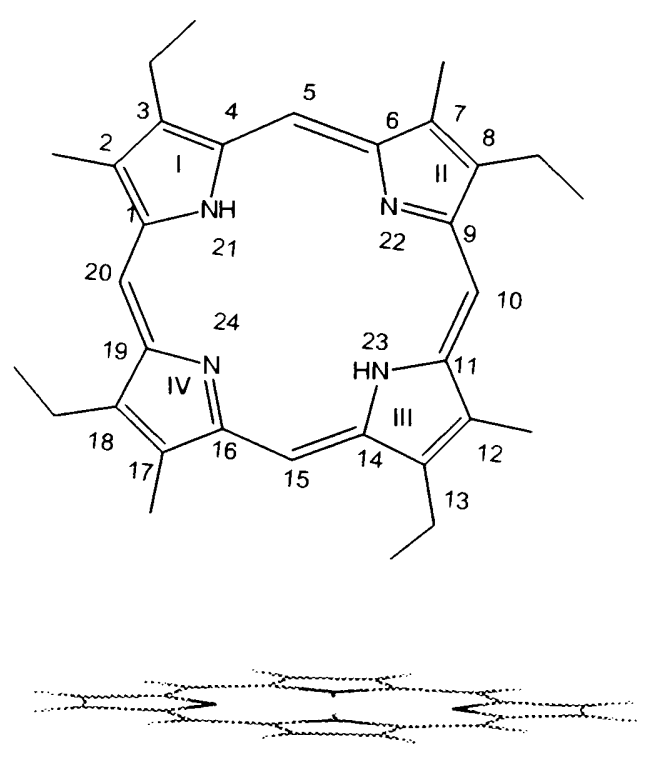

Free base $-\mathrm{MM}+\mathrm{OPT}$

a

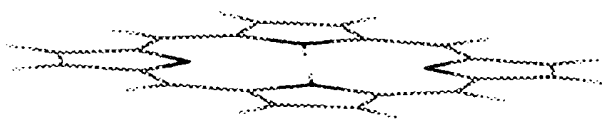

Free base - PM3PT

b

Figure 15. Optimized structures of

$\mathrm{H}_{2}$ ETIOl using $\mathrm{MM}+(\mathrm{a})$ and PM3(b) calculations. Peripheral substituents

have been replaced by hydrogens.

\section{$\mathrm{H}_{2}$ ETIO1 \\ MM+ OPT}

\begin{tabular}{|c|c|c|c|}
\hline $\begin{array}{l}\text { Bond lengths } \\
C_{2}-C_{3} \\
C_{7}-C_{8} \\
C_{12}-C_{13} \\
C_{17}-C_{18}\end{array}$ & 1.34 & $\begin{array}{l}\text { Distances } \\
C_{3}-C_{12} \\
C_{7}-C_{18}\end{array}$ & 8.11 \\
\hline $\begin{array}{l}\text { Meso angles } \\
C_{4}-C_{5}-C_{6} \\
C_{9}-C_{10}-C_{11} \\
C_{14}-C_{15}^{-}-C_{16} \\
C_{19}-C_{20}-C_{1}\end{array}$ & 127.32 & $\begin{array}{l}\text { Distances } \\
\mathrm{N}_{21}-\mathrm{N}_{23} \\
\mathrm{~N}_{22}-\mathrm{N}_{24}\end{array}$ & 3.97 \\
\hline $\begin{array}{l}\text { Tors. angle(rf) } \\
\mathrm{C}_{2}-\mathrm{C}_{3}-\mathrm{C}_{12}-\mathrm{C}_{13} \\
\mathrm{C}_{7}-\mathrm{C}_{8}-\mathrm{C}_{17}-\mathrm{C}_{18}\end{array}$ & 1.536 & $\begin{array}{l}\text { Distance } \\
\text { shortest } \\
\mathrm{N}_{21}-\mathrm{N}_{22} \\
\mathrm{~N}_{23}-\mathrm{N}_{24} \\
\end{array}$ & 2.81 \\
\hline $\begin{array}{l}\text { Tors. angle(sd) } \\
C_{1}-N_{21}-C_{4}-C_{5} \\
C_{6}-N_{22}-C_{9}-C_{10} \\
C_{11}-N_{23}-C_{14}-C_{15} \\
C_{16}-N_{24}-C_{19}-C_{20}\end{array}$ & 0.86 & $\begin{array}{l}\text { Distance } \\
\text { largest } \\
\mathrm{N}_{21}-\mathrm{N}_{24} \\
\mathrm{~N}_{22}-\mathrm{N}_{23}\end{array}$ & 2.81 \\
\hline
\end{tabular}

Table 5. Bond lengths, angles and distances obtained from the $\mathrm{MM}+$ optimized structure of $\mathrm{H}_{2}$ ETIOl. 

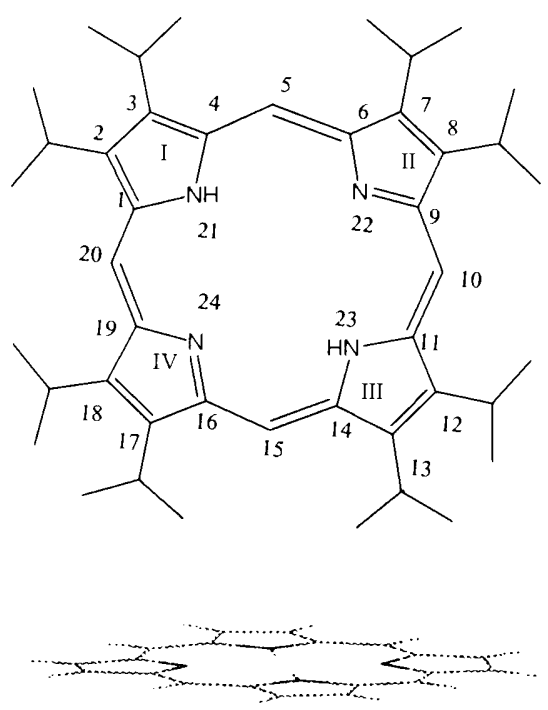

Free base - MM+OPT

a

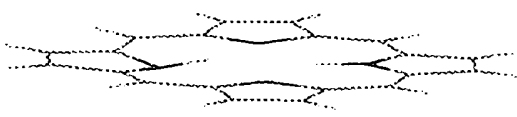

Free base - PM3 OPT

b

Figure 16. Optimized structures of $\mathrm{H}_{2}$ OIP using $\mathrm{MM}+(\mathrm{a})$ and $\mathrm{PM} 3(\mathrm{~b})$ calculations. Peripheral substituents have been replaced by hydrogens.

\section{$\mathrm{H}_{2} \mathrm{O}$ (iPr)P \\ $\mathrm{MM}+\mathrm{OPT}$}

\begin{tabular}{|c|c|c|c|}
\hline $\begin{array}{l}\text { Bond lengths } \\
\mathrm{C}_{2}-\mathrm{C}_{3} \\
\mathrm{C}_{7}-\mathrm{C}_{8} \\
\mathrm{C}_{12}-\mathrm{C}_{13} \\
\mathrm{C}_{17}-\mathrm{C}_{18}\end{array}$ & 1.35 & $\begin{array}{l}\text { Distances } \\
\mathrm{C}_{3}-\mathrm{C}_{12} \\
\mathrm{C}_{7}-\mathrm{C}_{18}\end{array}$ & 8.16 \\
\hline $\begin{array}{l}\text { Meso angles } \\
C_{4}-C_{5}-C_{6} \\
C_{9}^{\prime}-C_{10}^{\prime}-C_{11} \\
C_{14}^{\prime}-C_{15}^{\prime}-C_{16}^{\prime} \\
C_{19}^{\prime}-C_{20}^{\prime}-C_{1}^{\prime}\end{array}$ & 130.19 & $\begin{array}{l}\text { Distances } \\
\mathrm{N}_{21}-\mathrm{N}_{23} \\
\mathrm{~N}_{22}-\mathrm{N}_{24}\end{array}$ & 4.01 \\
\hline $\begin{array}{l}\text { Tors. angle(rf) } \\
C_{2}-C_{3}-C_{12}-C_{13} \\
C_{7}-C_{8}-C_{17}-C_{18}\end{array}$ & 5.26 & $\begin{array}{l}\text { Distance } \\
\text { shortest } \\
\mathrm{N}_{21}-\mathrm{N}_{22} \\
\mathrm{~N}_{23}-\mathrm{N}_{24} \\
\end{array}$ & 2.83 \\
\hline $\begin{array}{l}\text { Tors. angle(sd) } \\
\mathrm{C}_{1}-\mathrm{N}_{21}-\mathrm{C}_{4}-\mathrm{C}_{5} \\
\mathrm{C}_{6}-\mathrm{N}_{22}-\mathrm{C}_{9}-\mathrm{C}_{10} \\
\mathrm{C}_{11}-\mathrm{N}_{23}-\mathrm{C}_{14}-\mathrm{C}_{15} \\
\mathrm{C}_{16}-\mathrm{N}_{24}-\mathrm{C}_{19}-\mathrm{C}_{20}\end{array}$ & 1.51 & $\begin{array}{l}\text { Distance } \\
\text { largest } \\
\mathbf{N}_{21}-\mathbf{N}_{24} \\
\mathbf{N}_{22}-\mathbf{N}_{23}\end{array}$ & 2.84 \\
\hline
\end{tabular}

Table 6. Bond lengths, angles and distances obtained from the MM+ optimized structure of $\mathrm{H}_{2}$ OIP 

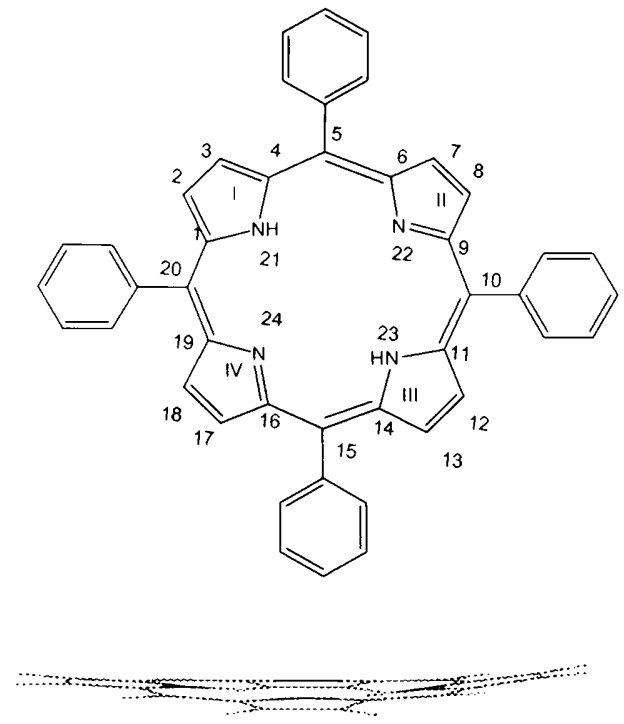

Free base - MM+ OPT

a

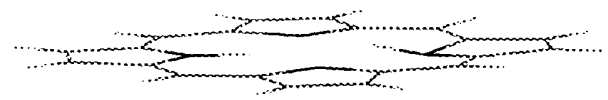

Free base - PM3 OPT

b

Figure 17. Optimized structures of $\mathrm{H}_{2}$ TPP using $\mathrm{MM}+(\mathrm{a})$ and PM3(b) calculations. Peripheral substituents have been replaced by hydrogens.
$\mathrm{H}_{2}$ TPP

$M M+O P T$

\begin{tabular}{|c|c|c|c|}
\hline $\begin{array}{l}\text { Bond lengths } \\
\mathrm{C}_{2}-\mathrm{C}_{3} \\
\mathrm{C}_{7}-\mathrm{C}_{8} \\
\mathrm{C}_{12}-\mathrm{C}_{13} \\
\mathrm{C}_{17}-\mathrm{C}_{18}\end{array}$ & 1.33 & $\begin{array}{l}\text { Distances } \\
C_{3}-C_{12} \\
C_{7}-C_{18}\end{array}$ & 8.10 \\
\hline $\begin{array}{l}\text { Meso angles } \\
C_{4}-C_{5}-C_{6} \\
C_{9}-C_{10}-C_{11} \\
C_{14}-C_{15}-C_{16} \\
C_{19}-C_{20}-C_{1}\end{array}$ & 123.75 & $\begin{array}{l}\text { Distances } \\
\mathbf{N}_{21}-\mathbf{N}_{23} \\
\mathbf{N}_{22}-\mathbf{N}_{24}\end{array}$ & 4.0 \\
\hline $\begin{array}{l}\text { Tors. angle(rf) } \\
C_{2}-C_{3}-C_{12}-C_{13} \\
C_{7}-C_{8}-C_{17}-C_{18}\end{array}$ & 1.99 & $\begin{array}{l}\text { Distance } \\
\text { shortest } \\
\mathbf{N}_{21}-\mathbf{N}_{22} \\
\mathbf{N}_{23}-\mathbf{N}_{24} \\
\end{array}$ & 2.77 \\
\hline $\begin{array}{l}\text { Tors. angle(sd) } \\
\mathrm{C}_{1}-\mathrm{N}_{21}-\mathrm{C}_{4}-\mathrm{C}_{5} \\
\mathrm{C}_{6}-\mathrm{N}_{22}-\mathrm{C}_{9}-\mathrm{C}_{10} \\
\mathrm{C}_{11}-\mathrm{N}_{23}-\mathrm{C}_{14}-\mathrm{C}_{15} \\
\mathrm{C}_{16}-\mathrm{N}_{24}-\mathrm{C}_{19}-\mathrm{C}_{20}\end{array}$ & 3.04 & $\begin{array}{l}\text { Distance } \\
\text { largest } \\
N_{21}-N_{24} \\
N_{22}-N_{23}\end{array}$ & 2.87 \\
\hline
\end{tabular}

Table 7. Bond lengths, angles and distances obtained from the $\mathrm{MM}+$ optimized structure of $\mathrm{H}_{2}$ TPP. 


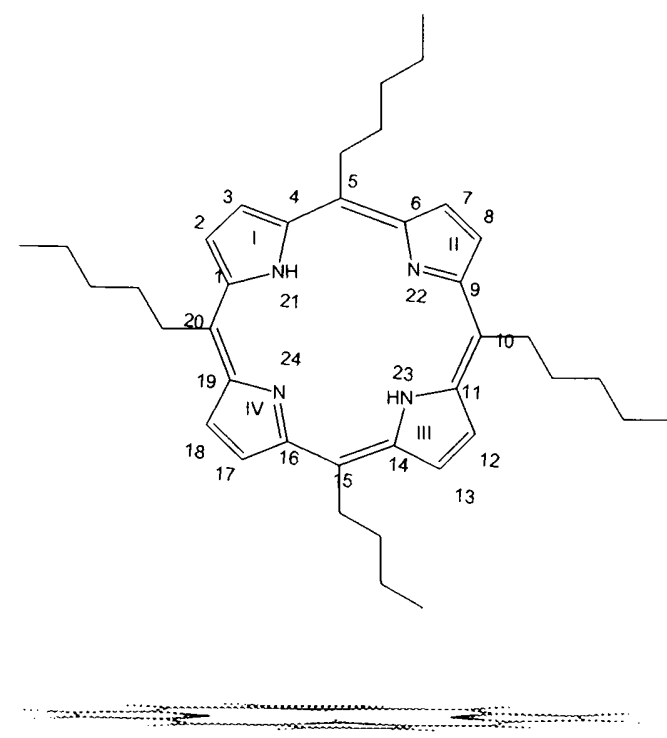

Free base $-\mathrm{MM}+\mathrm{OPT}$

a

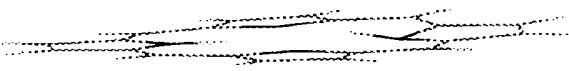

Free base - PM3 OPT

b
$\mathrm{H}_{2} \mathrm{~T}(\mathrm{nPe}) \mathrm{P}$

$M M+O P T$

\begin{tabular}{|c|c|c|c|}
\hline $\begin{array}{l}\text { Bond lengths } \\
C_{2}-C_{3} \\
C_{7}-C_{8}^{\prime} \\
C_{12}-C_{13} \\
C_{17}-C_{18} \\
\end{array}$ & 1.33 & $\begin{array}{l}\text { Distances } \\
C_{3}-C_{12} \\
C_{7}-C_{18}\end{array}$ & 8.07 \\
\hline $\begin{array}{l}\text { Meso angles } \\
C_{4}-C_{5}-C_{6} \\
C_{9}-C_{10}-C_{11} \\
C_{14}-C_{15}-C_{16} \\
C_{19}-C_{20}-C_{1}\end{array}$ & 123.48 & $\begin{array}{l}\text { Distances } \\
N_{21}-N_{23} \\
N_{22}-N_{24}\end{array}$ & 3.98 \\
\hline $\begin{array}{l}\text { Tors. angle( (rf) } \\
C_{2}-C_{3}-C_{12}-C_{13} \\
C_{7}-C_{8}-C_{17}-C_{18}\end{array}$ & 0.12 & $\begin{array}{l}\text { Distance } \\
\text { shortest } \\
N_{21}-N_{22} \\
N_{23}-N_{24} \\
\end{array}$ & 2.81 \\
\hline $\begin{array}{l}\text { Tors. angle(sd) } \\
\mathrm{C}_{1}-\mathrm{N}_{21}-\mathrm{C}_{4}-\mathrm{C}_{5} \\
\mathrm{C}_{6}-\mathrm{N}_{22}-\mathrm{C}_{9}-\mathrm{C}_{10} \\
\mathrm{C}_{11}-\mathrm{N}_{23}-\mathrm{C}_{14}-\mathrm{C}_{15} \\
\mathrm{C}_{16}-\mathrm{N}_{24}-\mathrm{C}_{19}-\mathrm{C}_{20}\end{array}$ & 0.92 & $\begin{array}{l}\text { Distance } \\
\text { la rgest } \\
\mathrm{N}_{21}-\mathrm{N}_{24} \\
\mathrm{~N}_{22}-\mathrm{N}_{23}\end{array}$ & 2.81 \\
\hline
\end{tabular}

Table 8. Bond lengths, angles and distances obtained from the MM+ optimized structure of $\mathrm{H}_{2} \mathrm{~T}(\mathrm{nPe}) \mathrm{P}$

Figure 18. Optimized structures of $\mathrm{H}_{2} \mathrm{~T}(\mathrm{nPe}) \mathrm{P}$ using $\mathrm{MM}+(\mathrm{a})$ and PM3(b)calculations. Peripheral substituents have been replaced by hydrogens. 

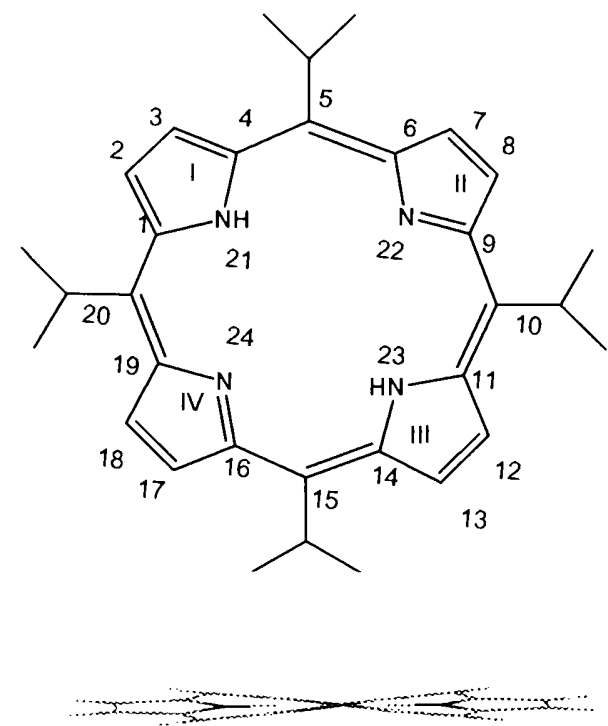

Free base - MM+ OPT

a

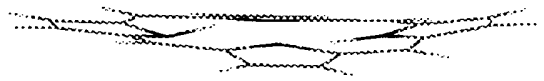

Free base - PM3 OPT

b

Figure 19. Optimized structures of $\mathrm{H}_{2} \mathrm{~T}(\mathrm{iPr}) \mathrm{P}$ using $\mathrm{MM}+(\mathrm{a})$ and PM3(b) calculations. Peripheral substituents have been replaced by hydrogens.
$\mathrm{H}_{2} \mathrm{~T}(\mathrm{iPr}) \mathrm{P}$

$M M+O P T$

\begin{tabular}{|c|c|c|c|}
\hline $\begin{array}{l}\text { Bond lengths } \\
C_{2}-C_{3} \\
C_{7}-C_{8} \\
C_{12}-C_{13} \\
C_{17}-C_{18}\end{array}$ & 1.33 & $\begin{array}{l}\text { Distances } \\
C_{3}-C_{12} \\
C_{7}-C_{18}\end{array}$ & 8.02 \\
\hline $\begin{array}{l}\text { Meso angles } \\
C_{4}-C_{5}-C_{6} \\
C_{9}-C_{10}-C_{11} \\
C_{14}-C_{15}-C_{16} \\
C_{19}-C_{20}-C_{1}\end{array}$ & 122.18 & $\begin{array}{l}\text { Distances } \\
\mathrm{N}_{21}-\mathrm{N}_{23} \\
\mathrm{~N}_{22}-\mathrm{N}_{24}\end{array}$ & 3.96 \\
\hline $\begin{array}{l}\text { Tors. angle(rf) } \\
C_{2}-C_{3}-C_{12}-C_{13} \\
C_{7}-C_{8}-C_{17}-C_{18}\end{array}$ & 20.93 & $\begin{array}{l}\text { Distance } \\
\text { shortest } \\
\mathrm{N}_{21}-\mathrm{N}_{22} \\
\mathrm{~N}_{23}-\mathrm{N}_{24} \\
\end{array}$ & 2.79 \\
\hline $\begin{array}{l}\text { Tors. angle(sd) } \\
\mathrm{C}_{1}-\mathrm{N}_{21}-\mathrm{C}_{4}-\mathrm{C}_{5} \\
\mathrm{C}_{6}-\mathrm{N}_{22}-\mathrm{C}_{9}-\mathrm{C}_{10} \\
\mathrm{C}_{11}-\mathrm{N}_{23}-\mathrm{C}_{14}-\mathrm{C}_{15} \\
\mathrm{C}_{16}-\mathrm{N}_{24}-\mathrm{C}_{19}-\mathrm{C}_{20}\end{array}$ & 5.63 & $\begin{array}{l}\text { Distance } \\
\text { largest } \\
\mathrm{N}_{21}-\mathrm{N}_{24} \\
\mathrm{~N}_{22}-\mathrm{N}_{23}\end{array}$ & 2.80 \\
\hline
\end{tabular}

Table 9. Bond lengths, angles and distances obtained from the MM+ optimized structure of $\mathrm{H}_{2} \mathrm{~T}(\mathrm{iPr}) \mathrm{P}$ 

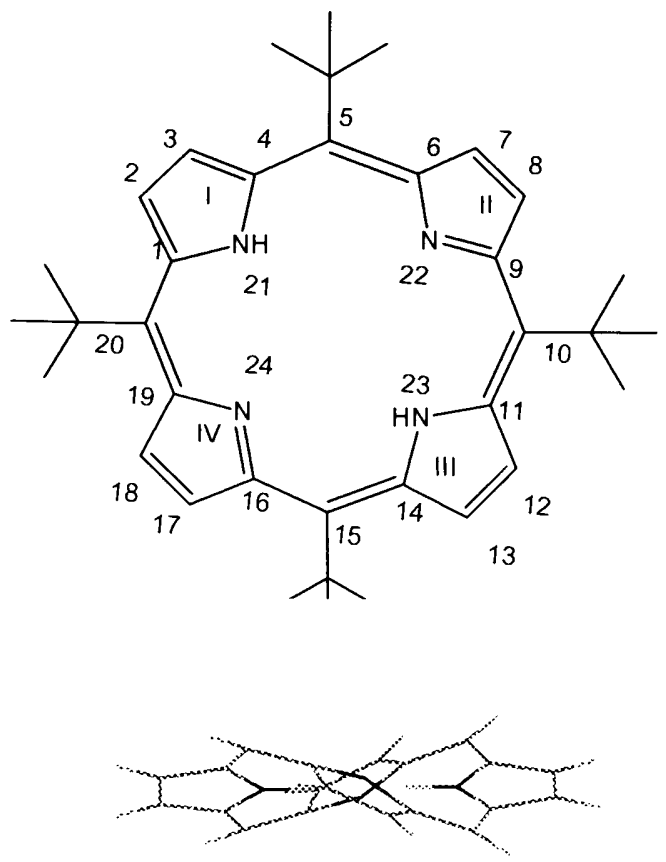

Free base $-\mathrm{MM}+\mathrm{OPT}$

a

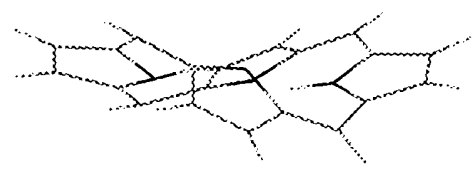

Free base - PM3 OPT

b

Figure 20. Optimized structures of $\mathrm{H}_{2} \mathrm{~T}(\mathrm{tBu}) \mathrm{P}$ using $\mathrm{MM}+(\mathrm{a})$ and PM3(b) calculations. Peripheral substituents have been replaced by hydrogens.

\section{$\mathrm{H}_{2} \mathrm{~T}(\mathrm{tBu}) \mathrm{P}$ \\ $M M+O P T$}

\begin{tabular}{|c|c|c|c|}
\hline $\begin{array}{l}\text { Bond lengths } \\
C_{2}-C_{3} \\
C_{7}-C_{8} \\
C_{12}-C_{13} \\
C_{17}-C_{18} \\
\end{array}$ & 1.33 & $\begin{array}{l}\text { Distances } \\
C_{3}-C_{12} \\
C_{7}-C_{18}\end{array}$ & 7.83 \\
\hline $\begin{array}{l}\text { Meso angles } \\
C_{4}-C_{5}-C_{6} \\
C_{9}-C_{10}-C_{11} \\
C_{14}-C_{15}-C_{16} \\
C_{19}-C_{20}-C_{1}\end{array}$ & 118.11 & $\begin{array}{l}\text { Distances } \\
\mathrm{N}_{21}-\mathrm{N}_{23} \\
\mathrm{~N}_{22}-\mathrm{N}_{24}\end{array}$ & 3.80 \\
\hline $\begin{array}{l}\text { Tors. angle(rf) } \\
C_{2}-C_{3}-C_{12}-C_{13} \\
C_{7}-C_{8}-C_{17}-C_{18}\end{array}$ & 46.52 & $\begin{array}{l}\text { Distance } \\
\text { shortest } \\
\mathrm{N}_{21}-\mathrm{N}_{22} \\
\mathrm{~N}_{23}-\mathrm{N}_{24} \\
\end{array}$ & 2.68 \\
\hline $\begin{array}{l}\text { Tors. angle(sd) } \\
C_{1}-N_{21}-C_{4}-C_{5} \\
C_{6}-N_{22}-C_{9}-C_{10} \\
C_{11}-N_{23}-C_{14}-C_{15} \\
C_{16}-N_{24}-C_{19}-C_{20}\end{array}$ & 8.43 & $\begin{array}{l}\text { Distance } \\
\text { la rgest } \\
\mathrm{N}_{21}-\mathrm{N}_{24} \\
\mathrm{~N}_{22}-\mathrm{N}_{23}\end{array}$ & 2.68 \\
\hline
\end{tabular}

Table 10. Bond lengths, angles and distances obtained from the $\mathrm{MM}+$ optimized structure of $\mathrm{H}_{2} \mathrm{~T}(\mathrm{tBu}) \mathrm{P}$ 


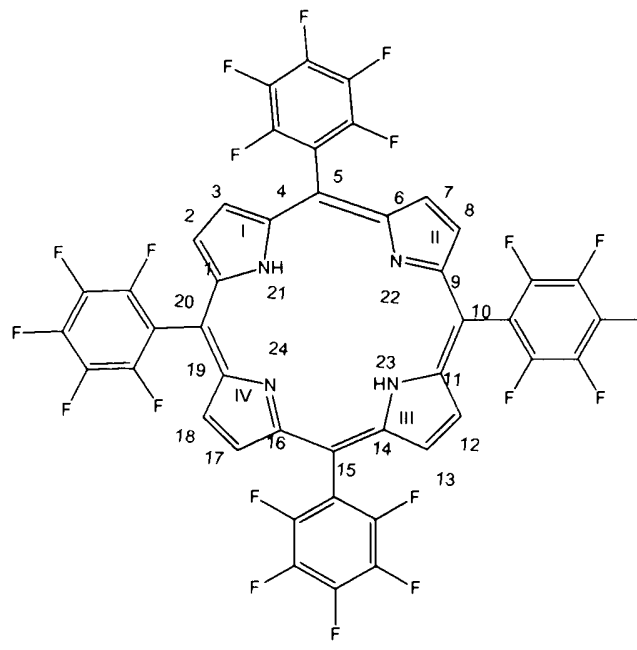

Free base $-\mathrm{MM}+\mathrm{OPT}$

a

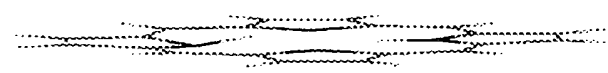

Free base - PM3 OPT

b

Figure 21. Optimized structures of $\mathrm{H}_{2}$ TFP using $\mathrm{MM}+(\mathrm{a})$ and $\mathrm{PM} 3(\mathrm{~b})$ calculations. Peripheral substituents have been replaced by hydrogens.
$\mathrm{H}_{2} \mathrm{~T}\left(\mathrm{nC}_{5} \mathrm{~F}_{5}\right) \mathrm{P}$

$\mathrm{MM}+\mathrm{OPT}$

\begin{tabular}{|l|l|l|l|}
\hline Bond lengths & & Distances & \\
$\mathbf{C}_{2}-\mathbf{C}_{3}$ & & \\
$\mathbf{C}_{7}-\mathbf{C}_{8}$ & 1.33 & $\mathbf{C}_{3}-\mathbf{C}_{12}$ & 8.08 \\
$\mathbf{C}_{12}-\mathbf{C}_{13}$ & & $\mathbf{C}_{7}-\mathbf{C}_{18}$ & \\
$\mathbf{C}_{17}-\mathbf{C}_{18}$ & & & \\
\hline Meso angles & & & \\
$\mathbf{C}_{4}-\mathbf{C}_{5}-\mathbf{C}_{6}$ & & Distances & \\
$\mathbf{C}_{9}-\mathbf{C}_{10}-\mathbf{C}_{11}$ & 124.02 & $\mathbf{N}_{21}-\mathbf{N}_{23}$ & 3.99 \\
$\mathbf{C}_{14}-\mathbf{C}_{15}-\mathbf{C}_{16}$ & & $\mathbf{N}_{22}-\mathbf{N}_{24}$ & \\
$\mathbf{C}_{19}-\mathbf{C}_{20}-\mathbf{C}_{1}$ & & & \\
\hline Tors. angle(rf) & & Distance & \\
$\mathbf{C}_{2}-\mathbf{C}_{3}-\mathbf{C}_{12}-\mathbf{C}_{13}$ & 1.61 & shortest & \multirow{2}{*}{2.77} \\
$\mathbf{C}_{7}-\mathbf{C}_{8}-\mathbf{C}_{17}-\mathbf{C}_{18}$ & & $\mathbf{N}_{21}-\mathbf{N}_{22}$ & \\
\hline Tors. angle(sd) & & $\mathbf{N}_{23}-\mathbf{N}_{24}$ & \\
$\mathbf{C}_{1}-\mathbf{N}_{21}-\mathbf{C}_{4}-\mathbf{C}_{5}$ & & Distance & \\
$\mathbf{C}_{6}-\mathbf{N}_{22}-\mathbf{C}_{9}-\mathbf{C}_{10}$ & 2.11 & argest & \multirow{2}{*}{2.87} \\
$\mathbf{C}_{11}-\mathbf{N}_{23}-\mathbf{C}_{14}-\mathbf{C}_{15}$ & & $\mathbf{N}_{21}-\mathbf{N}_{24}$ & \\
$\mathbf{C}_{16}-\mathbf{N}_{24}-\mathbf{C}_{19}-\mathbf{C}_{20}$ & & $\mathbf{N}_{22}-\mathbf{N}_{23}$ & \\
\hline
\end{tabular}

Table 11. Bond lengths, angles and distances obtained from the MM+ optimized structure of $\mathrm{H}_{2}$ TFP 

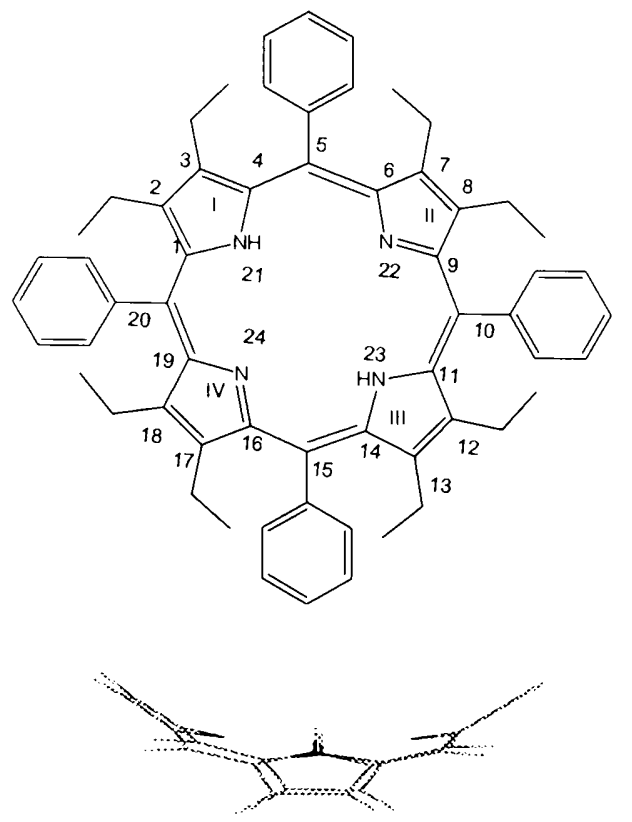

\begin{tabular}{|c|c|c|c|}
\hline $\begin{array}{l}\text { Bond lengths } \\
\mathrm{C}_{2}-\mathrm{C}_{3} \\
\mathrm{C}_{7}-\mathrm{C}_{8} \\
\mathrm{C}_{12}-\mathrm{C}_{13} \\
\mathrm{C}_{17}-\mathrm{C}_{18}\end{array}$ & 1.35 & $\begin{array}{l}\text { Distances } \\
C_{3}-C_{12} \\
C_{7}-C_{18}\end{array}$ & 7.14 \\
\hline $\begin{array}{l}\text { Meso angles } \\
C_{4}-C_{5}-C_{6} \\
C_{9}-C_{10}-C_{11} \\
C_{14}-C_{15}-C_{16} \\
C_{19}-C_{20}-C_{1}\end{array}$ & 122.11 & $\begin{array}{l}\text { Distances } \\
\mathrm{N}_{21}-\mathrm{N}_{23} \\
\mathrm{~N}_{22}-\mathrm{N}_{24}\end{array}$ & 3.77 \\
\hline $\begin{array}{l}\text { Tors. angle(rf) } \\
C_{2}-C_{3}-C_{12}-C_{13} \\
C_{7}-C_{8}-C_{17}-C_{18}\end{array}$ & 2.20 & $\begin{array}{l}\text { Distance } \\
\text { shortest } \\
\mathrm{N}_{21}-\mathrm{N}_{22} \\
\mathrm{~N}_{23}-\mathrm{N}_{24} \\
\end{array}$ & 2.68 \\
\hline $\begin{array}{l}\text { Tors. angle(sd) } \\
\mathrm{C}_{1}-\mathrm{N}_{21}-\mathrm{C}_{4}-\mathrm{C}_{5} \\
\mathrm{C}_{6}-\mathrm{N}_{22}-\mathrm{C}_{9}-\mathrm{C}_{10} \\
\mathrm{C}_{11}-\mathrm{N}_{23}-\mathrm{C}_{14}-\mathrm{C}_{15} \\
\mathrm{C}_{16}-\mathrm{N}_{24}-\mathrm{C}_{19}-\mathrm{C}_{20}\end{array}$ & 17.59 & $\begin{array}{l}\text { Distance } \\
\text { la rgest } \\
\mathrm{N}_{21}-\mathrm{N}_{24} \\
\mathrm{~N}_{22}-\mathrm{N}_{23}\end{array}$ & 2.69 \\
\hline
\end{tabular}

Free base - MM+ OPT

$\mathrm{H}_{2}$ OETPP $M M+O P T$

a

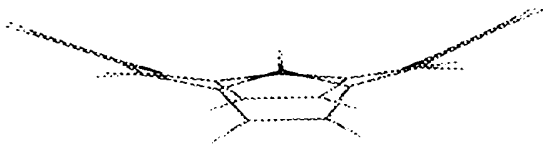

Table 12. Bond lengths, angles and distances obtained from the MM+ optimized structure of $\mathrm{H}_{2} \mathrm{OETPP}$

Free base - PM3 OPT

b

Figure 22. Optimized structures of $\mathrm{H}_{2}$ OETPP using $\mathrm{MM}+(\mathrm{a})$ and PM3(b) calculations. Peripheral substituents have been replaced by hydrogens. 


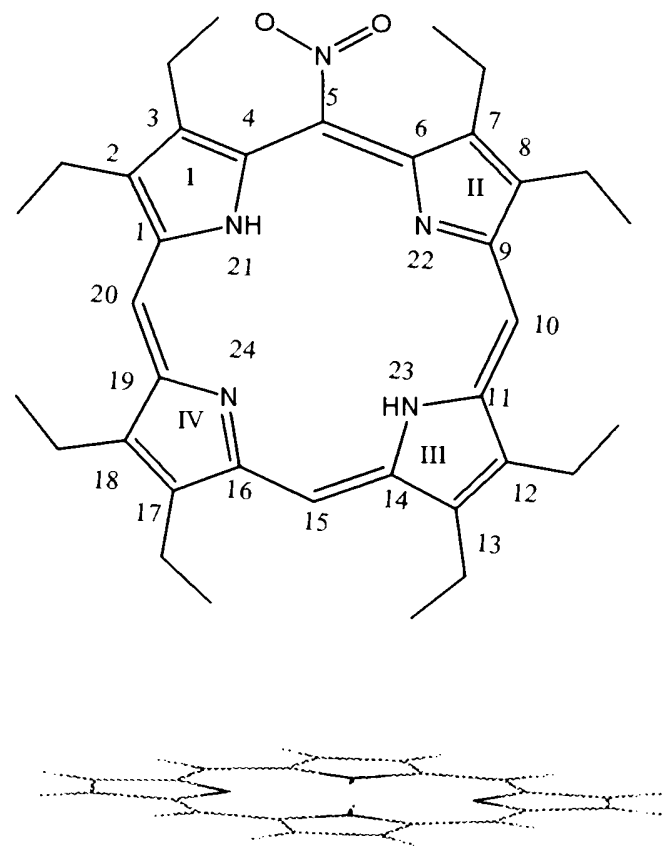

Free base - MM+ OPT

a

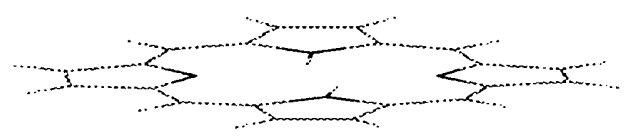

Free base - PM3 OPT

b
$\mathrm{H}_{2}$ 5-NO 2 OEP

$\mathrm{MM}+$ OPT

\begin{tabular}{|c|c|c|c|}
\hline $\begin{array}{l}\text { Bond lengths } \\
C_{2}-C_{3} \\
C_{7}-C_{8} \\
C_{12}-C_{13} \\
C_{17}-C_{18}\end{array}$ & 1.34 & $\begin{array}{l}\text { Distances } \\
C_{3}-C_{12} \\
C_{7}-C_{18}\end{array}$ & 8.13 \\
\hline $\begin{array}{l}\text { Meso angles } \\
C_{4}-C_{5}-C_{6} \\
C_{9}-C_{10}-C_{11} \\
C_{14}-C_{15}-C_{16} \\
C_{19}-C_{20}-C_{1}\end{array}$ & 128.64 & $\begin{array}{l}\text { Distances } \\
\mathrm{N}_{21}-\mathrm{N}_{23} \\
\mathrm{~N}_{22}-\mathrm{N}_{24}\end{array}$ & 3.99 \\
\hline $\begin{array}{l}\text { Tors. angle(rf) } \\
C_{2}-C_{3}-C_{12}-C_{13} \\
C_{7}-C_{8}-C_{17}-C_{18}\end{array}$ & 2.06 & $\begin{array}{l}\text { Distance } \\
\text { shortest } \\
\mathrm{N}_{21}-\mathrm{N}_{22} \\
\mathrm{~N}_{23}-\mathrm{N}_{24}\end{array}$ & 2.75 \\
\hline $\begin{array}{l}\text { Tors. angle(sd) } \\
\mathrm{C}_{1}-\mathrm{N}_{21}-\mathrm{C}_{4}-\mathrm{C}_{5} \\
\mathrm{C}_{6}-\mathrm{N}_{22}-\mathrm{C}_{9}-\mathrm{C}_{10} \\
\mathrm{C}_{11}-\mathrm{N}_{23}-\mathrm{C}_{14}-\mathrm{C}_{15} \\
\mathrm{C}_{16}-\mathrm{N}_{24}-\mathrm{C}_{19}-\mathrm{C}_{20}\end{array}$ & 1.05 & $\begin{array}{l}\text { Distance } \\
\text { la rgest } \\
\mathrm{N}_{21}-\mathrm{N}_{24} \\
\mathrm{~N}_{22}-\mathrm{N}_{23}\end{array}$ & 2.90 \\
\hline
\end{tabular}

Table 13. Bond lengths, angles and distances obtained from the $\mathrm{MM}+$ optimized structure of $\mathrm{H}_{2} 5 \mathrm{NO}_{2} \mathrm{OEP}$

Figure 23. Optimized structures of $\mathrm{H}_{2}$ 5-NO $\mathrm{N}_{2} \mathrm{OEP} \mathrm{MM+(a)} \mathrm{and} \mathrm{PM3(b)}$ calculations. Peripheral substituents have been replaced by hydrogens. 


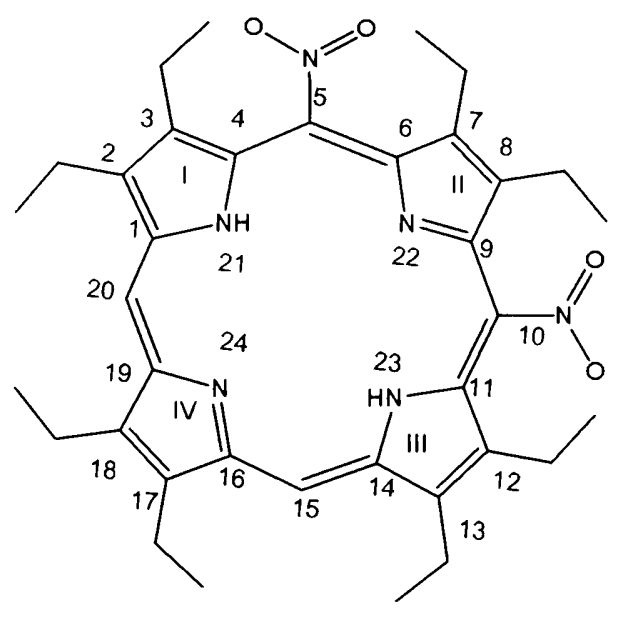

\section{$\mathrm{H}_{2}$ 5,10-diNO ${ }_{2}$ OEP \\ $\mathrm{MM}+\mathrm{OPT}$}

\begin{tabular}{|l|l|l|l|}
\hline Bond lengths & & & \\
$\mathbf{C}_{2}-\mathbf{C}_{3}$ & & Distances & \\
$\mathbf{C}_{7}-\mathbf{C}_{8}$ & 1.34 & $\mathbf{C}_{3}-\mathbf{C}_{12}$ & 8.14 \\
$\mathbf{C}_{12}-\mathbf{C}_{13}$ & & $\mathbf{C}_{7}-\mathbf{C}_{18}$ & \\
$\mathbf{C}_{17}-\mathbf{C}_{18}$ & & & \\
\hline Meso angles & & & \\
$\mathbf{C}_{4}-\mathbf{C}_{5}-\mathbf{C}_{6}$ & & Distances & \\
$\mathbf{C}_{9}-\mathbf{C}_{10}-\mathbf{C}_{11}$ & 129.183 & $\mathbf{N}_{21}-\mathbf{N}_{23}$ & 4.02 \\
$\mathbf{C}_{14}-\mathbf{C}_{15}-\mathbf{C}_{16}$ & & $\mathbf{N}_{22}-\mathbf{N}_{24}$ & \\
$\mathbf{C}_{19}-\mathbf{C}_{20}-\mathbf{C}_{1}$ & & & \\
\hline Tors. angle(rf) & & Distance & \\
$\mathbf{C}_{2}-\mathbf{C}_{3}-\mathbf{C}_{12}-\mathbf{C}_{13}$ & 2.88 & shortest & \multirow{2}{*}{2.84} \\
$\mathbf{C}_{7}-\mathbf{C}_{8}-\mathbf{C}_{17}-\mathbf{C}_{18}$ & & $\mathbf{N}_{21}-\mathbf{N}_{22}$ & \\
\hline Tors. angle(sd) & & $\mathbf{N}_{23}-\mathbf{N}_{24}$ & \\
$\mathbf{C}_{1}-\mathbf{N}_{21}-\mathbf{C}_{4}-\mathbf{C}_{5}$ & & Distance & \\
$\mathbf{C}_{6}-\mathbf{N}_{22}-\mathbf{C}_{9}-\mathbf{C}_{10}$ & 3.39 & largest $_{10}$ & \multirow{2}{*}{2.84} \\
$\mathbf{C}_{11}-\mathbf{N}_{23}-\mathbf{C}_{14}-\mathbf{C}_{15}$ & & $\mathbf{N}_{21}-\mathbf{N}_{24}$ & \\
$\mathbf{C}_{16}-\mathbf{N}_{24}-\mathbf{C}_{19}-\mathbf{C}_{20}$ & & $\mathbf{N}_{22}-\mathbf{N}_{23}$ & \\
\hline
\end{tabular}

a

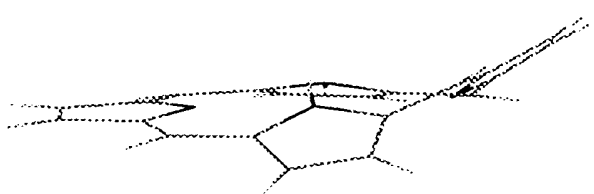

Table 14. Bond lengths, angles and distances obtained from the $\mathrm{MM}+$ optimized structure of $\mathrm{H}_{2} 5,10-\mathrm{NO}_{2} \mathrm{OEP}$

Free base - PM3 OPT

b

Figure 24. Optimized structures of $\mathrm{H}_{2} 5,10-\mathrm{NO}_{2} \mathrm{OEP}$ using $\mathrm{MM}+(\mathrm{a})$ and PM3(b) calculations. Peripheral substituents have been replaced by hydrogens. 

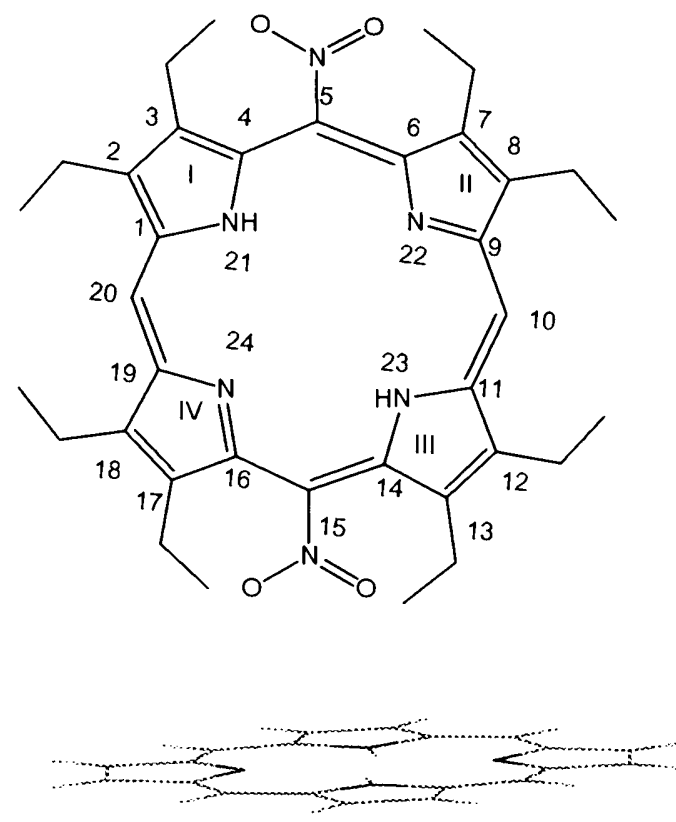

Free base $-\mathrm{MM}+\mathrm{OPT}$

\section{$\mathrm{H}_{2}$ 5,15-diNO ${ }_{2}$ OEP \\ $\mathrm{MM}+$ OPT}

\begin{tabular}{|c|c|c|c|}
\hline $\begin{array}{l}\text { Bond lengths } \\
C_{2}-C_{3} \\
C_{7}-C_{8} \\
C_{12}-C_{13} \\
C_{17}-C_{18}\end{array}$ & 1.34 & $\begin{array}{l}\text { Distances } \\
C_{3}-C_{12} \\
C_{7}-C_{18}\end{array}$ & 8.14 \\
\hline $\begin{array}{l}\text { Meso angles } \\
C_{4}-C_{5}-C_{6} \\
C_{9}-C_{10}-C_{11} \\
C_{14}-C_{15}-C_{16} \\
C_{19}-C_{20}-C_{1}\end{array}$ & 129.61 & $\begin{array}{l}\text { Distances } \\
\mathrm{N}_{21}-\mathrm{N}_{23} \\
\mathrm{~N}_{22}-\mathrm{N}_{24}\end{array}$ & 4.04 \\
\hline $\begin{array}{l}\text { Tors. angle(rf) } \\
C_{2}-C_{3}-C_{12}-C_{13} \\
C_{7}-C_{8}-C_{17}-C_{18}\end{array}$ & 0.48 & $\begin{array}{l}\text { Distance } \\
\text { shortest } \\
\mathrm{N}_{21}-\mathrm{N}_{22} \\
\mathrm{~N}_{23}-\mathrm{N}_{24}\end{array}$ & 2.7 \\
\hline $\begin{array}{l}\text { Tors. angle(sd) } \\
\mathrm{C}_{1}-\mathrm{N}_{21}-\mathrm{C}_{4}-\mathrm{C}_{5} \\
\mathrm{C}_{6}-\mathrm{N}_{22}-\mathrm{C}_{9}-\mathrm{C}_{10} \\
\mathrm{C}_{11}-\mathrm{N}_{23}-\mathrm{C}_{14}-\mathrm{C}_{15} \\
\mathrm{C}_{16}-\mathrm{N}_{24}-\mathrm{C}_{19}-\mathrm{C}_{20}\end{array}$ & 2.80 & $\begin{array}{l}\text { Distance } \\
\text { la rgest } \\
\mathrm{N}_{21}-\mathrm{N}_{24} \\
\mathrm{~N}_{22}-\mathrm{N}_{23}\end{array}$ & 3.01 \\
\hline
\end{tabular}

a

Table 15. Bond lengths, angles and distances obtained from the $\mathrm{MM}+$ optimized structure of $\mathrm{H}_{2} 5,15-\mathrm{NO}_{2} \mathrm{OEP}$

Free base - PM3 OPT

b

Figure 25. Optimized structures of $\mathrm{H}_{2}$ 5, 15- $\mathrm{NO}_{2} \mathrm{OEP}$ using $\mathrm{MM}+(\mathrm{a})$ and PM3(b) calculations. Peripheral substituents have been replaced by hydrogens. 


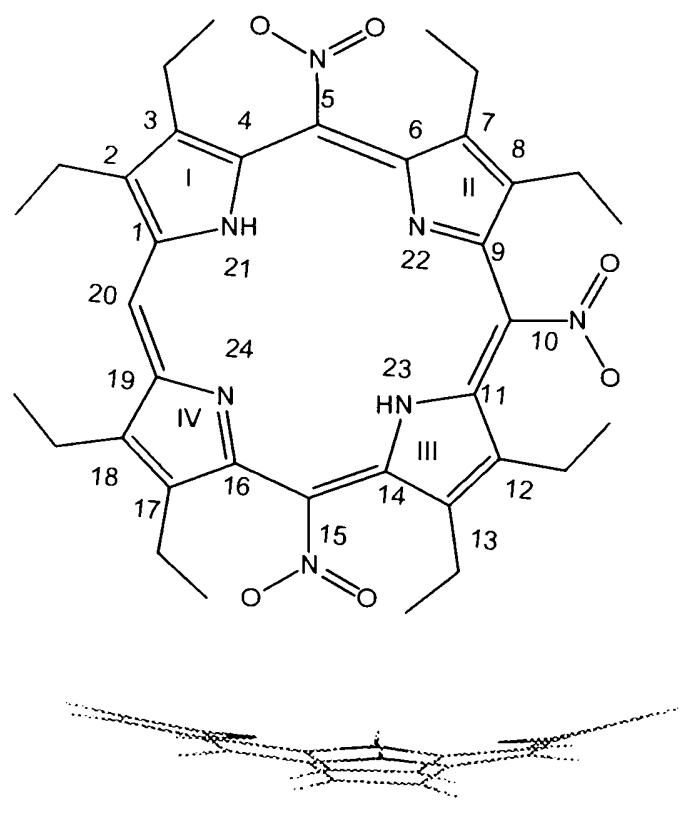

Free base - MM+ OPT

a

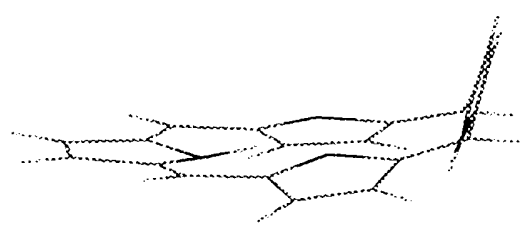

Free base - PM3 OPT

b

Figure 26. Optimized structures of $\mathrm{H}_{2} 5,10,15$ triNO $_{2} \mathrm{OEP}$ using $\mathrm{MM}+(\mathrm{a})$ and PM3(b) calculations. Peripheral substituents have been replaced by hydrogens.

\section{$\mathrm{H}_{2}$ 5,10,15-triNO ${ }_{2} \mathrm{OEP}$ $\mathrm{MM}+\mathrm{OPT}$}

\begin{tabular}{|c|c|c|c|}
\hline $\begin{array}{l}\text { Bond lengths } \\
C_{2}-C_{3} \\
C_{7}-C_{8} \\
C_{12}-C_{13} \\
C_{17}-C_{18} \\
\end{array}$ & 1.35 & $\begin{array}{l}\text { Distances } \\
C_{3}-C_{12} \\
C_{7}-C_{18}\end{array}$ & 7.97 \\
\hline $\begin{array}{l}\text { Meso angles } \\
C_{4}-C_{5}-C_{6} \\
C_{9}-C_{10}-C_{11} \\
C_{14}-C_{15}-C_{16} \\
C_{19}-C_{20}-C_{1}\end{array}$ & 129.20 & $\begin{array}{l}\text { Distances } \\
\mathrm{N}_{21}-\mathrm{N}_{23} \\
\mathrm{~N}_{22}-\mathrm{N}_{24}\end{array}$ & 3.93 \\
\hline $\begin{array}{l}\text { Tors. angle(rf) } \\
C_{2}-C_{3}-C_{12}-C_{13} \\
C_{7}-C_{8}-C_{17}-C_{18}\end{array}$ & 1.45 & $\begin{array}{l}\text { Distance } \\
\text { shortest } \\
\mathrm{N}_{21}-\mathrm{N}_{22} \\
\mathrm{~N}_{23}-\mathrm{N}_{24}\end{array}$ & 2.74 \\
\hline $\begin{array}{l}\text { Tors. angle(sd) } \\
\mathrm{C}_{1}-\mathrm{N}_{21}-\mathrm{C}_{4}-\mathrm{C}_{5} \\
\mathrm{C}_{6}-\mathrm{N}_{22}-\mathrm{C}_{9}-\mathrm{C}_{10} \\
\mathrm{C}_{11}-\mathrm{N}_{23}-\mathrm{C}_{14}-\mathrm{C}_{15} \\
\mathrm{C}_{16}-\mathrm{N}_{24}-\mathrm{C}_{19}-\mathrm{C}_{20}\end{array}$ & 8.84 & $\begin{array}{l}\text { Distance } \\
\text { largest } \\
N_{21}-N_{24} \\
N_{22}-N_{23}\end{array}$ & 2.92 \\
\hline
\end{tabular}

Table 16. Bond lengths, angles and distances obtained from the $\mathrm{MM}+$ optimized structure of $\mathrm{H}_{2} 5,10,15$ triNO $_{2} \mathrm{OEP}$ 

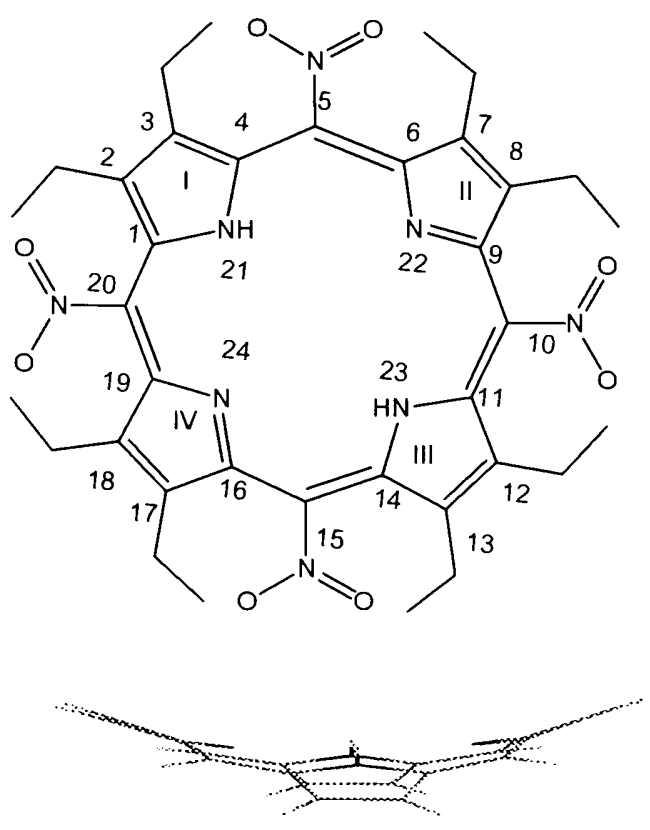

Free base - MM+ OPT

a

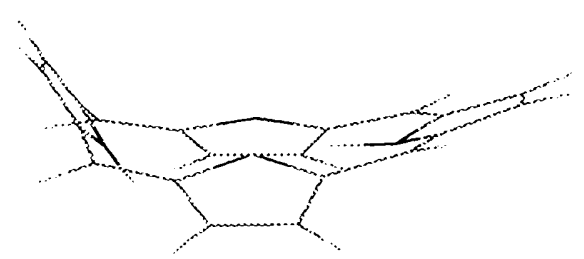

Free base - PM3 OPT

b

Figure 27. Optimized structures of $\mathrm{H}_{2}$ tetraNO $\mathrm{O}_{2} \mathrm{OEP}$ using $\mathrm{MM}+(\mathrm{a})$ and PM3(b) calculations. Peripheral substituents have been replaced by hydrogens.

\section{$\mathrm{H}_{2} 5,10,15,20$-tetraNO ${ }_{2} \mathrm{OEP}$ MM+ OPT}

\begin{tabular}{|c|c|c|c|}
\hline $\begin{array}{l}\text { Bond lengths } \\
\mathrm{C}_{2}-\mathrm{C}_{3} \\
\mathrm{C}_{7}-\mathrm{C}_{8} \\
\mathrm{C}_{12}-\mathrm{C}_{13} \\
\mathrm{C}_{17}-\mathrm{C}_{18}\end{array}$ & 1.35 & $\begin{array}{l}\text { Distances } \\
C_{3}-C_{12} \\
C_{7}-C_{18}\end{array}$ & 7.77 \\
\hline $\begin{array}{l}\text { Meso angles } \\
C_{4}-C_{5}-C_{6} \\
C_{9}-C_{10}-C_{11} \\
C_{14}-C_{15}-C_{16} \\
C_{19}-C_{20}-C_{1}\end{array}$ & 128.48 & $\begin{array}{l}\text { Distances } \\
\mathrm{N}_{21}-\mathrm{N}_{23} \\
\mathrm{~N}_{22}-\mathrm{N}_{24}\end{array}$ & 3.93 \\
\hline $\begin{array}{l}\text { Tors. angle(rf) } \\
C_{2}-C_{3}-C_{12}-C_{13} \\
C_{7}-C_{8}-C_{17}-C_{18}\end{array}$ & 2.22 & $\begin{array}{l}\text { Distance } \\
\text { shortest } \\
N_{21}-N_{22} \\
N_{23}-N_{24}\end{array}$ & 2.8 \\
\hline $\begin{array}{l}\text { Tors. angle(sd) } \\
\mathrm{C}_{1}-\mathrm{N}_{21}-\mathrm{C}_{4}-\mathrm{C}_{5} \\
\mathrm{C}_{6}-\mathrm{N}_{22}-\mathrm{C}_{9}-\mathrm{C}_{10} \\
\mathrm{C}_{11}-\mathrm{N}_{23}-\mathrm{C}_{14}-\mathrm{C}_{15} \\
\mathrm{C}_{16}-\mathrm{N}_{24}-\mathrm{C}_{19}-\mathrm{C}_{20}\end{array}$ & 12.50 & $\begin{array}{l}\text { Distance } \\
\text { la rgest } \\
\mathrm{N}_{21}-\mathrm{N}_{24} \\
\mathrm{~N}_{22}-\mathrm{N}_{23}\end{array}$ & 2.8 \\
\hline
\end{tabular}

Table 17. Bond lengths, angles and distances obtained from the $\mathrm{MM}+$ optimized structure of $\mathrm{H}_{2}$ tetraNO $\mathrm{N}_{2} \mathrm{OEP}$ 


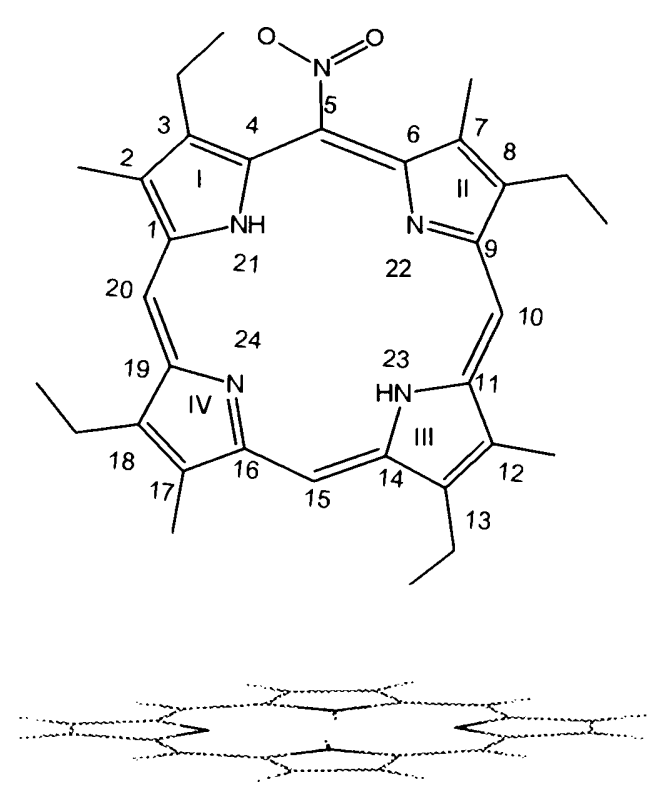

Free base $-\mathrm{MM}+\mathrm{OPT}$

a

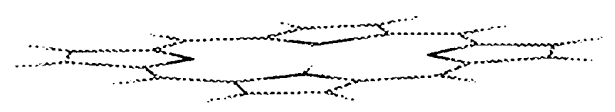

Free base - PM3 OPT

b

Figure 28. Optimized structures of $\mathrm{H}_{2}$ - $-\mathrm{NO}_{2}$ ETIOl using $\mathrm{MM}+(\mathrm{a})$ and PM3(b) calculations. Peripheral substituents have been replaced by hydrogens.

\section{$\mathrm{H}_{2} 5-\mathrm{NO}_{2} \mathrm{ETIO} 1$ \\ MM+ OPT}

\begin{tabular}{|c|c|c|c|}
\hline $\begin{array}{l}\text { Bond lengths } \\
C_{2}-C_{3} \\
C_{7}-C_{8} \\
C_{12}-C_{13} \\
C_{17}-C_{18}\end{array}$ & 1.34 & $\begin{array}{l}\text { Distances } \\
C_{3}-C_{12} \\
C_{7}-C_{18}\end{array}$ & 8.15 \\
\hline $\begin{array}{l}\text { Meso angles } \\
C_{44}-C_{5}-C_{6} \\
C_{9}-C_{10}-C_{11} \\
C_{14}-C_{15}-C_{16} \\
C_{19}-C_{20}-C_{1} \\
\end{array}$ & 128.24 & $\begin{array}{l}\text { Distances } \\
\mathrm{N}_{21}-\mathrm{N}_{23} \\
\mathrm{~N}_{22}-\mathrm{N}_{24}\end{array}$ & 4.0 \\
\hline $\begin{array}{l}\text { Tors. angle(rf) } \\
\mathrm{C}_{2}-\mathrm{C}_{3}-\mathbf{C}_{12}-\mathbf{C}_{13} \\
\mathrm{C}_{7}-\mathrm{C}_{8}-\mathrm{C}_{17}-\mathrm{C}_{18}\end{array}$ & 1.01 & $\begin{array}{l}\text { Distance } \\
\text { shortest } \\
\mathrm{N}_{21}-\mathrm{N}_{22} \\
\mathrm{~N}_{23}-\mathrm{N}_{24} \\
\end{array}$ & 2.75 \\
\hline $\begin{array}{l}\text { Tors. angle(sd) } \\
\mathrm{C}_{1}-\mathrm{N}_{21}-\mathrm{C}_{4}-\mathrm{C}_{5} \\
\mathrm{C}_{6}-\mathrm{N}_{22}-\mathrm{C}_{9}-\mathrm{C}_{10} \\
\mathrm{C}_{11}-\mathrm{N}_{23}-\mathrm{C}_{14}-\mathrm{C}_{15} \\
\mathrm{C}_{16}-\mathrm{N}_{24}-\mathrm{C}_{19}-\mathrm{C}_{20}\end{array}$ & 0.66 & $\begin{array}{l}\text { Distance } \\
\text { la rgest } \\
\mathrm{N}_{21}-\mathrm{N}_{24} \\
\mathrm{~N}_{22}-\mathrm{N}_{23} \\
\end{array}$ & 2.9 \\
\hline
\end{tabular}

Table 18. Bond lengths, angles and distances obtained from the MM+ optimized structure of $\mathrm{H}_{2} 5-\mathrm{NO}_{2}$ Etio $\mathrm{l}$ 


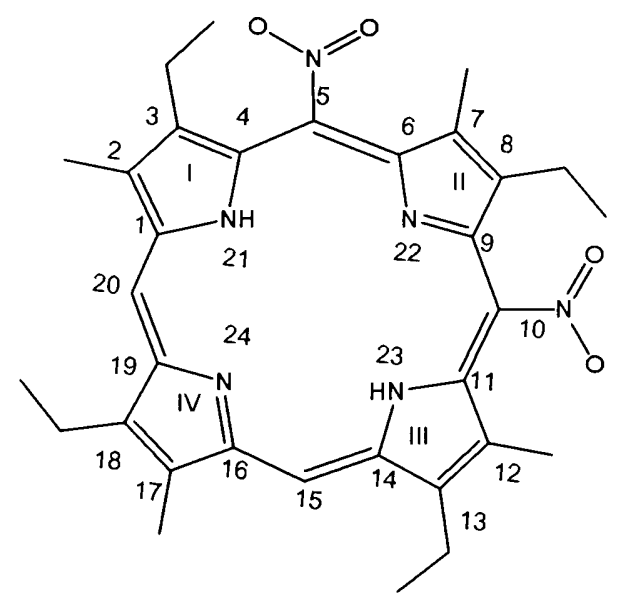

Free base - MM+ OPT

a

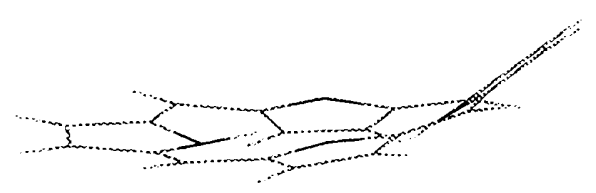

Free base - PM3 OPT

b
$\mathrm{H}_{2}$ 5,10-diNO $\mathrm{ETIO}$

$\mathrm{MM}+\mathrm{OPT}$

\begin{tabular}{|c|c|c|c|}
\hline $\begin{array}{l}\text { Bond lengths } \\
\mathrm{C}_{2}-\mathrm{C}_{3} \\
\mathrm{C}_{7}-\mathrm{C}_{8} \\
\mathrm{C}_{12}-\mathrm{C}_{13} \\
\mathrm{C}_{17}-\mathrm{C}_{18} \\
\end{array}$ & 1.34 & $\begin{array}{l}\text { Distances } \\
\mathrm{C}_{3}-\mathrm{C}_{12} \\
\mathrm{C}_{7}-\mathrm{C}_{18}\end{array}$ & 8.09 \\
\hline $\begin{array}{l}\text { Meso angles } \\
C_{4}-C_{5}-C_{6} \\
C_{9}-C_{10}-C_{11} \\
C_{14}-C_{15}-C_{16} \\
C_{19}-C_{20}-C_{1}\end{array}$ & 128.72 & $\begin{array}{l}\text { Distances } \\
N_{21}-N_{23} \\
N_{22}-N_{24}\end{array}$ & 4.01 \\
\hline $\begin{array}{l}\text { Tors. angle(rf) } \\
C_{2}-C_{3}-C_{12}-C_{13} \\
C_{7}-C_{8}-C_{17}-C_{18}\end{array}$ & 3.33 & $\begin{array}{l}\text { Distance } \\
\text { shortest } \\
\mathrm{N}_{21}-\mathrm{N}_{22} \\
\mathrm{~N}_{23}-\mathrm{N}_{24}\end{array}$ & 2.83 \\
\hline $\begin{array}{l}\text { Tors. angle(sd) } \\
\mathrm{C}_{1}-\mathrm{N}_{21}-\mathrm{C}_{4}-\mathrm{C}_{5} \\
\mathrm{C}_{6}-\mathrm{N}_{22}-\mathrm{C}_{9}-\mathrm{C}_{10} \\
\mathrm{C}_{11}-\mathrm{N}_{23}-\mathrm{C}_{14}-\mathrm{C}_{15} \\
\mathrm{C}_{16}-\mathrm{N}_{24}-\mathrm{C}_{19}-\mathrm{C}_{20}\end{array}$ & 3.49 & $\begin{array}{l}\text { Distance } \\
\text { la rgest } \\
N_{21}-N_{24} \\
N_{22}-N_{23}\end{array}$ & 2.84 \\
\hline
\end{tabular}

Table 19. Bond lengths, angles and distances obtained from the $\mathrm{MM}+$ optimized structure of $\mathrm{H}_{2} 5,10-\mathrm{NO}_{2}$ Etio $\mathrm{l}$

Figure 29. Optimized structures of $\mathrm{H}_{2} 5,10-\mathrm{NO}_{2}$ ETIOl using $\mathrm{MM}+(\mathrm{a})$ and PM3(b) calculations. Peripheral substituents have been replaced by hydrogens. 

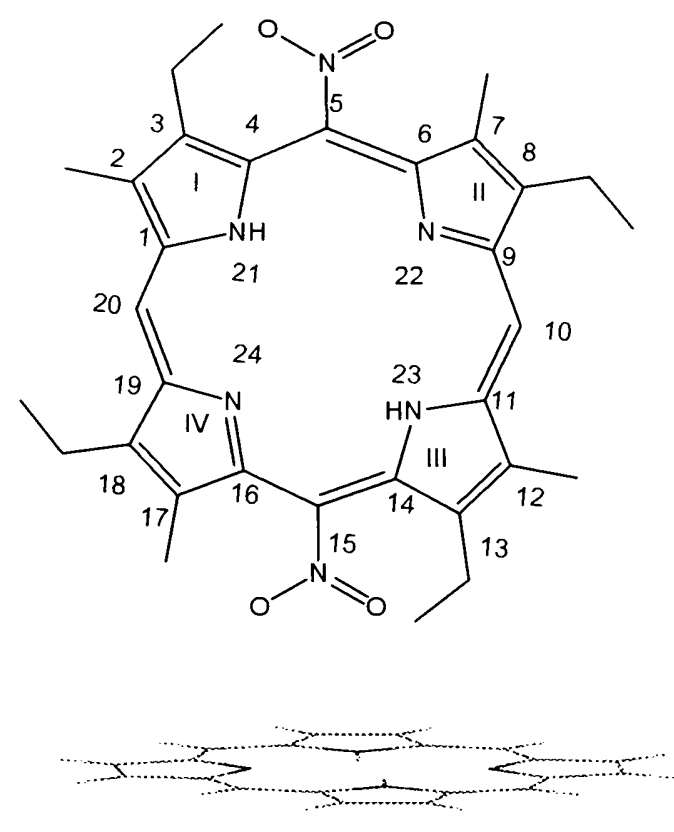

Free base - MM+ OPT

\section{$\mathrm{H}_{2}$ 5,15-diNO $\mathrm{ETIO}$ $M M+O P T$}

\begin{tabular}{|c|c|c|c|}
\hline $\begin{array}{l}\text { Bond lengths } \\
\mathrm{C}_{2}-\mathrm{C}_{3} \\
\mathrm{C}_{7}-\mathrm{C}_{8} \\
\mathrm{C}_{12}-\mathrm{C}_{13} \\
\mathrm{C}_{17}-\mathrm{C}_{18} \\
\end{array}$ & 1.34 & $\begin{array}{l}\text { Distances } \\
C_{3}-C_{12} \\
C_{7}-C_{18}\end{array}$ & 8.16 \\
\hline $\begin{array}{l}\text { Meso angles } \\
C_{4}-C_{5}-C_{6} \\
C_{9}-C_{10}-C_{11} \\
C_{14}-C_{15}-C_{16} \\
C_{19}-C_{20}-C_{1}\end{array}$ & 129.31 & $\begin{array}{l}\text { Distances } \\
\mathrm{N}_{21}-\mathrm{N}_{23} \\
\mathrm{~N}_{22}-\mathrm{N}_{24}\end{array}$ & 4.04 \\
\hline $\begin{array}{l}\text { Tors. angle(rf) } \\
C_{2}-C_{3}-C_{12}-C_{13} \\
C_{7}-C_{8}-C_{17}-C_{18}\end{array}$ & 1.20 & $\begin{array}{l}\text { Distance } \\
\text { shortest } \\
\mathrm{N}_{21}-\mathrm{N}_{22} \\
\mathrm{~N}_{23}-\mathrm{N}_{24} \\
\end{array}$ & 2.71 \\
\hline $\begin{array}{l}\text { Tors. angle(sd) } \\
C_{1}-N_{21}-C_{4}-C_{5} \\
C_{6}-N_{22}-C_{9}-C_{10} \\
C_{11}-N_{23}-C_{14}-C_{15} \\
C_{16}-N_{24}-C_{19}-C_{20}\end{array}$ & 0.68 & $\begin{array}{l}\text { Distance } \\
\text { la rgest } \\
\mathrm{N}_{21}-\mathrm{N}_{24} \\
\mathrm{~N}_{22}-\mathrm{N}_{23}\end{array}$ & 2.99 \\
\hline
\end{tabular}

Table 20. Bond lengths, angles and distances obtained from the $\mathrm{MM}+$ optimized structure of $\mathrm{H}_{2} 5,15-\mathrm{NO}_{2}$ Etiol

Free base - PM3 OPT

b

Figure 30. Optimized structures of $\mathrm{H}_{2}$, 15- $\mathrm{NO}_{2}$ ETIOl using $\mathrm{MM}+(\mathrm{a})$ and PM3(b) calculations. Peripheral substituents have been replaced by hydrogens. 


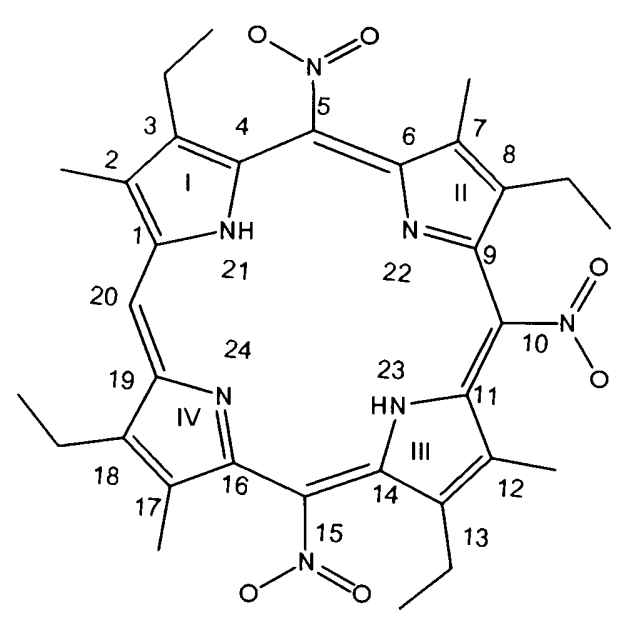

Free base $-\mathrm{MM}+\mathrm{OPT}$

a

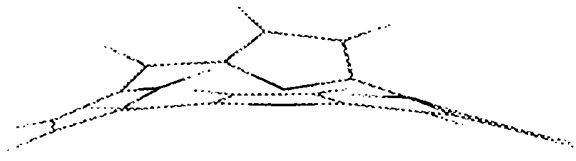

Free base - PM3 OPT

$\mathrm{b}$

Figure 31. Optimized structures of $\mathrm{H}_{2} 5,10,15-\mathrm{NO}_{2}$ ETIO1 using $\mathrm{MM}+(\mathrm{a})$ and PM3(b) calculations. Peripheral substituents have been replaced by hydrogens.

\section{$\mathrm{H}_{2}$ 5,10,15-triNO $\mathrm{ETIO}$ $\mathrm{MM}+\mathrm{OPT}$}

\begin{tabular}{|c|c|c|c|}
\hline $\begin{array}{l}\text { Bond lengths } \\
C_{2}-C_{3} \\
C_{7}-C_{8} \\
C_{12}-C_{13} \\
C_{17}-C_{18}\end{array}$ & 1.34 & $\begin{array}{l}\text { Distances } \\
C_{3}-C_{12} \\
C_{7}-C_{18}\end{array}$ & 8.0 \\
\hline $\begin{array}{l}\text { Meso angles } \\
\mathrm{C}_{4}-\mathrm{C}_{5}-\mathrm{C}_{6} \\
\mathrm{C}_{9}-\mathrm{C}_{10}-\mathrm{C}_{11} \\
\mathrm{C}_{14}-\mathrm{C}_{15}-\mathrm{C}_{16} \\
\mathrm{C}_{19}-\mathrm{C}_{20}-\mathrm{C}_{1} \\
\end{array}$ & 128.90 & $\begin{array}{l}\text { Distances } \\
\mathrm{N}_{21}-\mathrm{N}_{23} \\
\mathrm{~N}_{22}-\mathrm{N}_{24}\end{array}$ & 3.98 \\
\hline $\begin{array}{l}\text { Tors. angle(rf) } \\
C_{2}-C_{3}-C_{12}-C_{13} \\
C_{7}^{\prime}-C_{8}-C_{17}-C_{18}\end{array}$ & 2.51 & $\begin{array}{l}\text { Distance } \\
\text { shortest } \\
\mathrm{N}_{21}-\mathrm{N}_{22} \\
\mathrm{~N}_{23}-\mathrm{N}_{24} \\
\end{array}$ & 2.77 \\
\hline $\begin{array}{l}\text { Tors. angle(sd) } \\
\mathrm{C}_{1}-\mathrm{N}_{21}-\mathrm{C}_{4}-\mathrm{C}_{5} \\
\mathrm{C}_{6}-\mathrm{N}_{22}-\mathrm{C}_{9}-\mathrm{C}_{10} \\
\mathrm{C}_{11}-\mathrm{N}_{23}-\mathrm{C}_{14}-\mathrm{C}_{15} \\
\mathrm{C}_{16}-\mathrm{N}_{24}-\mathrm{C}_{19}-\mathrm{C}_{20}\end{array}$ & 8.58 & $\begin{array}{l}\text { Distance } \\
\text { largest } \\
\mathrm{N}_{21}-\mathrm{N}_{24} \\
\mathrm{~N}_{22}-\mathrm{N}_{23}\end{array}$ & 2.88 \\
\hline
\end{tabular}

Table 21. Bond lengths, angles and distances obtained from the $\mathrm{MM}+$ optimized structure of $\mathrm{H}_{2} 5,10,15-\mathrm{NO}_{2}$ Etiol 

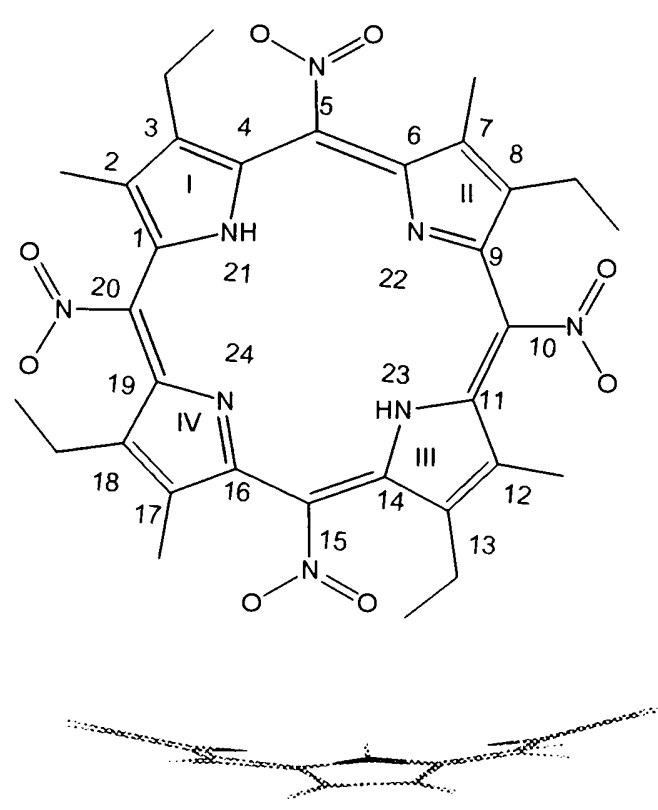

Free base - MM+OPT

a

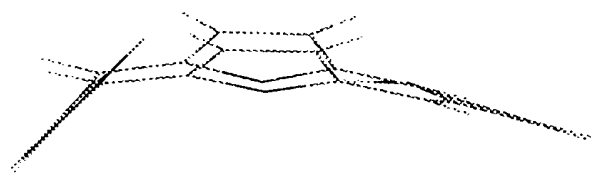

Free base - PM3 OPT

b

Figure 32. Optimized structures of $\mathrm{H}_{2}$ tetraNO $\mathrm{O}_{2}$ ETIOl using $\mathrm{MM}+(\mathrm{a})$ and PM3(b) calculations. Peripheral substituents have been replaced by hydrogens.

\section{$\mathrm{H}_{2} 5,10,15,20$-tetraNO ${ }_{2}$ ETIO1 $\mathrm{MM}+$ OPT}

\begin{tabular}{|c|c|c|c|}
\hline $\begin{array}{l}\text { Bond lengths } \\
C_{2}-C_{3} \\
C_{7}-C_{8} \\
C_{12}-C_{13} \\
C_{17}-C_{18}\end{array}$ & 1.34 & $\begin{array}{l}\text { Distances } \\
C_{3}-C_{12} \\
C_{7}-C_{18}\end{array}$ & 7.79 \\
\hline $\begin{array}{l}\text { Meso angles } \\
C_{4}-C_{5}-C_{6} \\
C_{9}-C_{10}-C_{11} \\
C_{14}-C_{15}-C_{16} \\
C_{19}-C_{20}-C_{1}\end{array}$ & 128.40 & $\begin{array}{l}\text { Distances } \\
\mathbf{N}_{21}-\mathbf{N}_{23} \\
\mathbf{N}_{22}-\mathbf{N}_{24}\end{array}$ & 3.93 \\
\hline $\begin{array}{l}\text { Tors. angle(rf) } \\
C_{2}-C_{3}-C_{12}-C_{13} \\
C_{7}-C_{8}-C_{17}-C_{18}\end{array}$ & 5.21 & $\begin{array}{l}\text { Distance } \\
\text { shortest } \\
\mathrm{N}_{21}-\mathrm{N}_{22} \\
\mathrm{~N}_{23}-\mathrm{N}_{24} \\
\end{array}$ & 2.80 \\
\hline $\begin{array}{l}\text { Tors. angle(sd) } \\
\mathrm{C}_{1}-\mathrm{N}_{21}-\mathrm{C}_{4}-\mathrm{C}_{5} \\
\mathrm{C}_{6}-\mathrm{N}_{22}-\mathrm{C}_{9}-\mathrm{C}_{10} \\
\mathrm{C}_{11}-\mathrm{N}_{23}-\mathrm{C}_{14}-\mathrm{C}_{15} \\
\mathrm{C}_{16}-\mathrm{N}_{24}-\mathrm{C}_{19}-\mathrm{C}_{20}\end{array}$ & 10.45 & $\begin{array}{l}\text { Distance } \\
\text { la rgest } \\
\mathrm{N}_{21}-\mathrm{N}_{24} \\
\mathrm{~N}_{22}-\mathrm{N}_{23}\end{array}$ & 2.80 \\
\hline
\end{tabular}

Table 22. Bond lengths, angles and distances obtained from the MM+ optimized structure of $\mathrm{H}_{2}$ tetraNO $\mathrm{O}_{2}$ Etiol 
Table 23. Parameters and distortions associated to non- planar distortions obtained from molecular mechanics calculations.

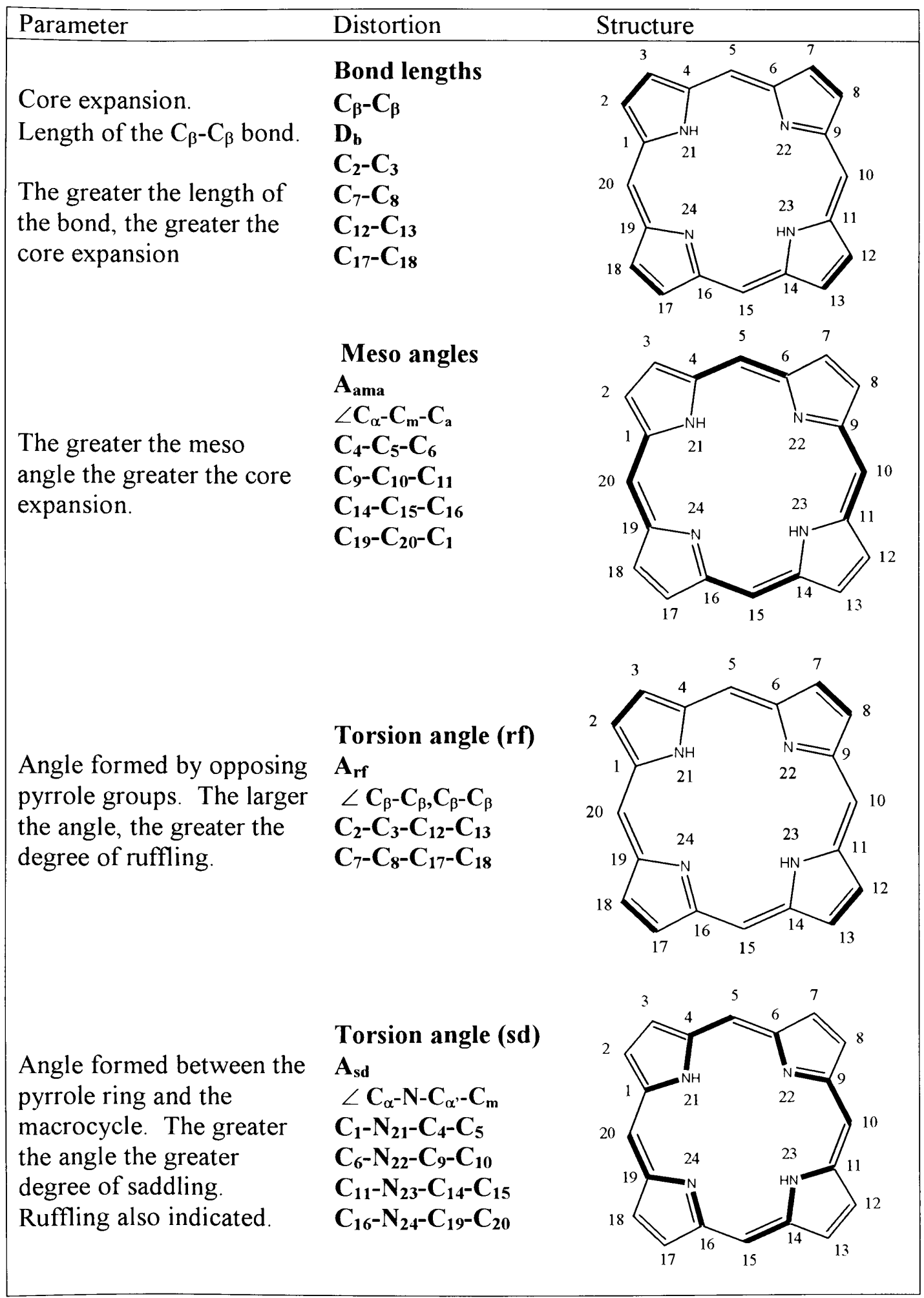




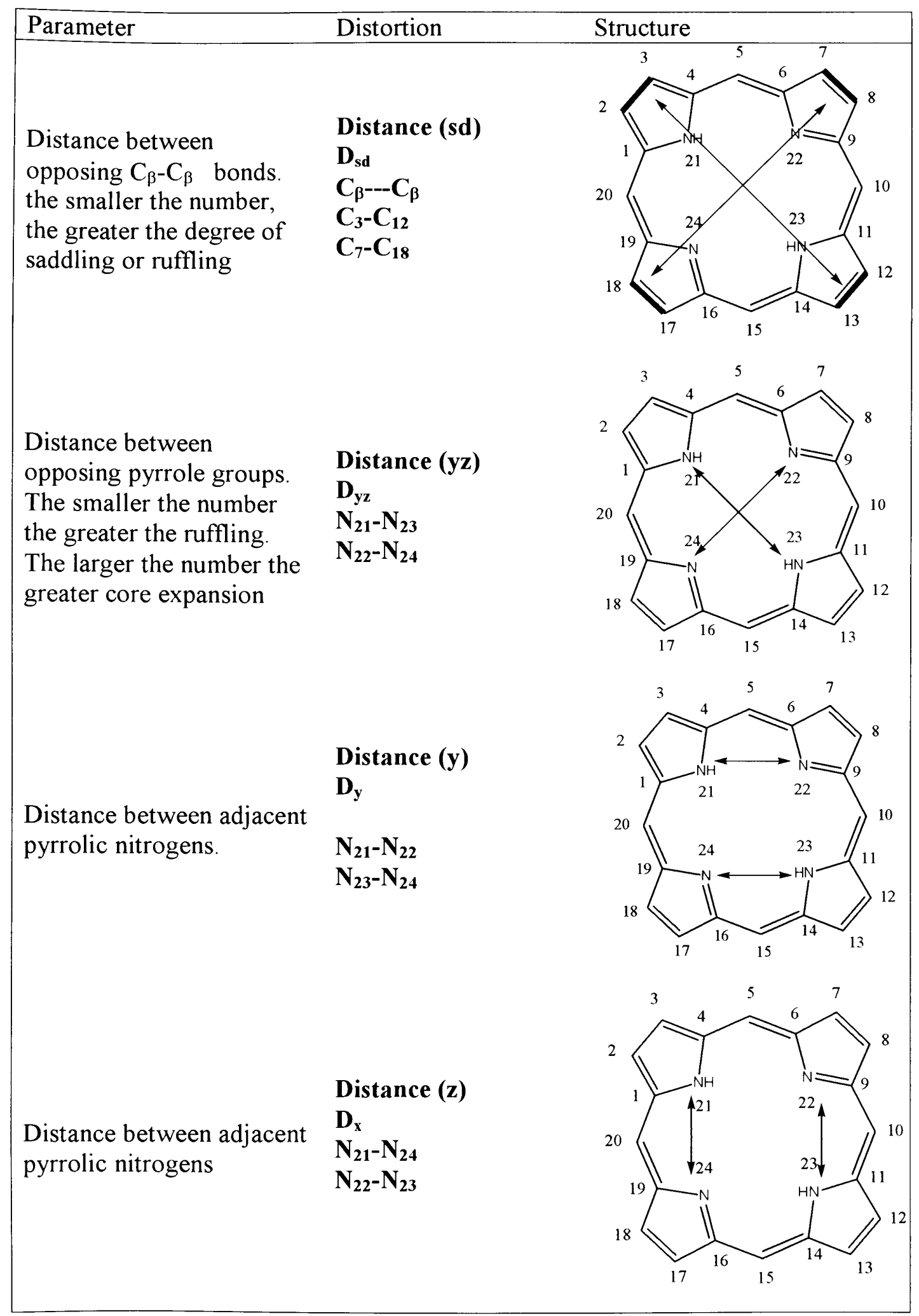




\subsubsection{Validity of the optimized structures}

Molecular Mechanics methods since 1990 have been used in well over 200 papers on porphyrins and heme proteins. In most cases these calculations have given accurate results which have been used in interpreting experimental data. [43, 47] Shellnutt's group has used such methods, with slightly modified force fields, to model different metalloporphyrins. These metalloporphyrins were then studied using Resonance Raman Spectroscopy and their structures were determined using Normal Structural Decomposition, a method developed by the same group. These predicted structures have been found to be very accurate. Additionally Medforth et al. evaluated these predictions for both free-base and constrained metal porphyrins and found that the calculated structures closely match the crystal structures.[26]

In Table 24 (a) and (b) we show a preliminary analysis comparing several averaged X-ray parameters reported for $\mathrm{H}_{2} \mathrm{OEP}$ and $\mathrm{H}_{2} \mathrm{TPP}$ and the parameters obtained from the molecular mechanics optimized structures reported herein. It must be pointed out that the results from the modeling studies do not take into account crystal packing forces so the parameters do not necessarily have to be identical. There is great similarity in the calculated parameters and those generated from the X-Ray crystal structures. We feel that the MM+ optimized structures are indicative of the actual structure of the free bases in solution. 
Table 24. Comparison of MM+ and X-ray crystal structure of $\mathrm{H}_{2} \mathrm{TPP}(8)$ and $\mathrm{H}_{2} \mathrm{OEP}$ (5).

\begin{tabular}{|l|c|c|c|}
\hline $\begin{array}{c}\text { Bond length } \\
\text { and angles }\end{array}$ & $\begin{array}{c}\text { MM+ } \\
\text { (Average) }\end{array}$ & $\begin{array}{c}\text { X-Ray } \\
\text { (Average) }\end{array}$ & $\begin{array}{c}\% \\
\text { difference }\end{array}$ \\
\hline \multicolumn{4}{|c|}{$\mathbf{H}_{\mathbf{2}}$ TPP (8) } \\
\hline $\mathrm{N}-\mathrm{C} \alpha(\AA)$ & 1.35 & 1.37 & 1.22 \\
$\mathrm{C} \alpha-\mathrm{C} \beta(\AA)$ & 1.34 & 1.44 & 6.88 \\
$\mathrm{C} \beta-\mathrm{C} \beta(\AA)$ & 1.34 & 1.35 & 1.37 \\
$\mathrm{C} \alpha-\mathrm{N}-\mathrm{C} \alpha 1\left(^{\circ}\right)$ & 107.53 & 107.7 & 0.16 \\
$\mathrm{~N}-\mathrm{C} \alpha-\mathrm{C} \beta\left(^{\circ}\right)$ & 107.59 & 108.8 & 1.11 \\
$\mathrm{C} \alpha-\mathrm{C} \beta-\mathrm{C} \beta\left(^{\circ}\right)$ & 108.4 & 107.45 & 0.89 \\
$\mathrm{~N}-\mathrm{C} \alpha-\mathrm{Cm}\left(^{\circ}\right)$ & 127.15 & 126.15 & 0.79 \\
$\mathrm{C} \beta-\mathrm{C} \alpha-\mathrm{Cm}\left(^{\circ}\right)$ & 125.09 & 125.05 & 0.03 \\
\hline \multicolumn{4}{|c}{$\mathbf{H}_{\mathbf{2}} \mathbf{O E P}(\mathbf{5})$} \\
\hline $\mathrm{N}-\mathrm{C} \alpha(\AA)$ & 1.35 & 1.37 & 1.41 \\
$\mathrm{C} \alpha-\mathrm{C} \beta(\AA)$ & 1.35 & 1.45 & 7.23 \\
$\mathrm{C} \beta-\mathrm{C} \beta(\AA)$ & 1.34 & 1.36 & 1.37 \\
$\mathrm{C} \alpha-\mathrm{N}-\mathrm{C} \alpha 1\left(^{\circ}\right)$ & 105.9 & 107.65 & 1.63 \\
$\mathrm{~N}-\mathrm{C} \alpha-\mathrm{C} \beta\left(^{\circ}\right)$ & 109.67 & 109.25 & 0.38 \\
$\mathrm{C} \alpha-\mathrm{C} \beta-\mathrm{C} \beta\left(^{\circ}\right)$ & 107.38 & 106.85 & 0.5 \\
$\mathrm{~N}-\mathrm{C} \alpha-\mathrm{Cm}\left(^{\circ}\right)$ & 124.13 & 125.05 & 0.74 \\
$\mathrm{C} \beta-\mathrm{C} \alpha-\mathrm{Cm}\left(^{\circ}\right)$ & 126.2 & 125.65 & 0.44 \\
\hline
\end{tabular}



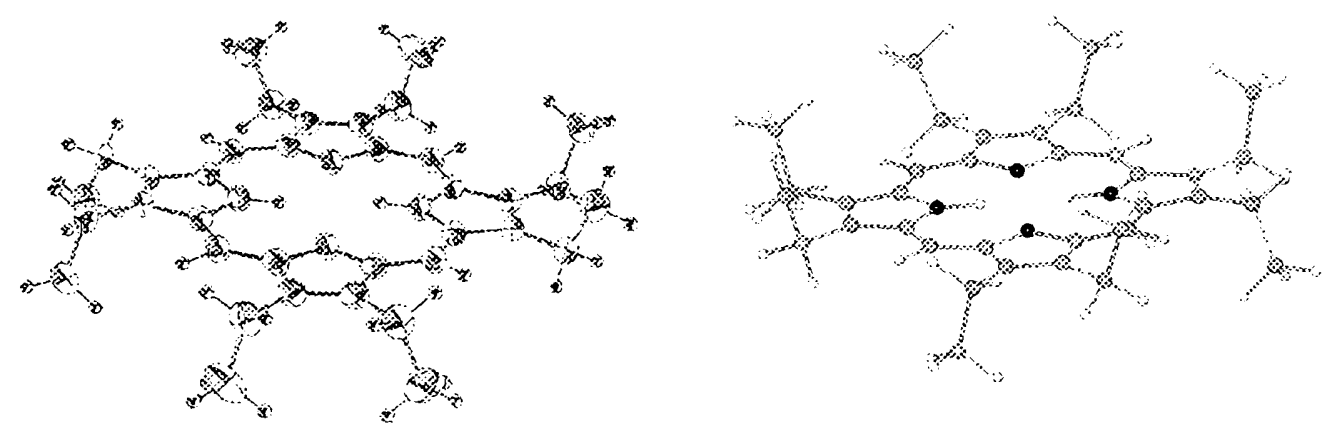

Figure 33. X-ray crystal structure of $\mathrm{H}_{2} \mathrm{OEP}$ (a) [58] and final optimized structure of $\mathrm{H}_{2} \mathrm{OEP}$ obtained using molecular mechanics calculations (b).

Several different types of core deformations are observed for symmetrically substituted porphyrin free bases. These are in plane and out-of-plane deformations. Two of the more important in-plane deformations are core expansion and rhombic distortions. Three of the measured parameters are sensitive to core expansion, these are the average length of the $C_{\beta}-C_{\beta}$ bond, $D_{b b}$; the average magnitude of the meso angle $\angle C_{\alpha}-C_{m}-C_{\alpha}, A_{a m a}$ and the average distance between opposing pyrrole groups, $\left(D_{y z}\right)$. These only validly measure the core expansion when the molecule is planar. Rhombic distortions occur in all porphyrins. It is the difference in distance between opposing pyrrolic nitrogens. The protonated pair is always separated more than the pair which is not protonated. We do not consider rhombic distortions herein.

Out of plane distortions occur when the macrocycle is no longer planar and these have already been described. The most sensitive measures for ruffling are the angles formed between the two opposing pyrrole groups $\angle C_{\beta}-C_{\beta}, C_{\beta}-C_{\beta} A_{r f}$; the average distance between opposing nitrogens $\left(\mathrm{D}_{\mathrm{yz}}\right)$ and the angle formed between the pyrrole rings and the plane formed by the macrocycle $\angle \mathrm{C}_{\alpha}-\mathrm{N}-\mathrm{C}_{\alpha}-\mathrm{C}_{\mathrm{m}}, \mathrm{A}_{\mathrm{sd}}$. Saddling is best 
indicated by the torsion angle $A_{s d}$, and by the distance between opposing $D_{s d}$ bonds.

Asymmetrically substituted porphyrins, such as the $\mathrm{NO}_{2}$ porphyrins will show

asymmetrical distortions. These parameters are the distance between the adjacent

nitrogens. When asymmetrically substituted there are two distances, $D_{y}$ and $D_{z}$. All of these are described in table 25 .

Table 25. Sumary of structural parameters generated using MM+ Optimization.

\begin{tabular}{|c|c|c|c|c|c|c|c|c|c|}
\hline Porphyrin free base & $\begin{array}{l}\text { Structu } \\
\text { re } \\
\mathrm{MM}+ \\
\text { opt. }\end{array}$ & $\begin{array}{l}C_{\beta}-C_{\beta} \\
\text { bond } \\
\text { lengths } \\
D_{b b}\end{array}$ & $\begin{array}{l}\text { meso } \\
\text { angles } \\
\mathrm{A}_{\text {ama }}\end{array}$ & $\begin{array}{l}\text { tors. } \\
\text { angle } \\
A_{r f}\end{array}$ & $\begin{array}{l}\text { tors. } \\
\text { angle } \\
\mathrm{A}_{\mathrm{sd}}\end{array}$ & $\begin{array}{l}C_{\beta} \cdots C_{\beta} \\
\text { opposing } \\
\beta \text {-carbons } \\
D_{\text {sd }}\end{array}$ & $\begin{array}{l}\text { N---N } \\
\text { opposing } \\
\text { pyrroles } \\
D_{\text {ya }}\end{array}$ & $\begin{array}{l}\mathrm{N}---\mathrm{N} \\
\text { adjacent } \\
\mathrm{D}_{\mathrm{z}}\end{array}$ & $\begin{array}{l}\mathrm{N}---\mathrm{N} \\
\text { adjacent } \\
\mathrm{D}_{\mathrm{y}}\end{array}$ \\
\hline $\mathrm{H}_{2} \mathrm{OEP}$ & Planar & 1.343 & 127.5 & 1.68 & 0.50 & 8.116 & 3.971 & 2.81 & 2.81 \\
\hline $\mathrm{H}_{2} 5-\mathrm{NO}_{2}$ ETIOI & Planar & 1.343 & 128.2 & 1.01 & 0.66 & 8.148 & 4.000 & 2.75 & 2.9 \\
\hline $\mathrm{H}_{2} 5,15-\mathrm{diNO}_{2}$ ETIOI & Planar & 1.344 & 129.3 & 1.2 & 0.68 & 8.159 & 4.039 & 2.71 & 2.99 \\
\hline $\mathrm{H}_{2}$ ETIOI & Planar & 1.343 & 127.3 & 1.54 & 0.86 & 8.113 & 3.968 & 2.81 & 2.81 \\
\hline $\mathrm{H}_{2} \mathrm{~T}(\mathrm{nPe}) \mathrm{P}$ & Planar & 1.333 & 123.5 & 0.12 & 0.92 & 8.073 & 3.978 & 2.81 & 2.81 \\
\hline $\mathrm{H}_{2} 5-\mathrm{NO}_{2} \mathrm{OEP}$ & Planar & 1.344 & 128.6 & 2.06 & 1.05 & 8.133 & 4.005 & 2.75 & 2.9 \\
\hline $\mathrm{H}_{2} \mathrm{OIP}$ & Planar & 1.351 & 130.2 & 5.26 & 1.51 & 8.156 & 4.011 & 2.83 & 2.84 \\
\hline $\mathrm{H}_{2} \mathrm{~T}\left(\mathrm{C}_{6} \mathrm{~F}_{5}\right) \mathrm{P}$ & Planar & 1.333 & 124 & 1.61 & 2.11 & 8.085 & 3.995 & 2.77 & 2.87 \\
\hline $\mathrm{H}_{2} 5,15-\mathrm{diNO}_{2} \mathrm{OEP}$ & Planar & 1.344 & 129.6 & 0.48 & 2.80 & 8.144 & 4.044 & 2.7 & 3.01 \\
\hline $\mathrm{H}_{2} 5,10-\mathrm{diNO}_{2} \mathrm{OEP}$ & Planar & 1.345 & 129.2 & 2.88 & 3.39 & 8.141 & 4.019 & 2.84 & 2.84 \\
\hline $\mathrm{H}_{2} \mathrm{TPP}$ & Planar & 1.332 & 123.7 & 1.99 & 3.4 & 8.097 & 4.001 & 2.77 & 2.87 \\
\hline $\mathrm{H}_{2} 5,10$-diNO ${ }_{2}$ ETIOI & Planar & 1.344 & 128.7 & 3.33 & 3.49 & 8.09 & 4.009 & 2.83 & 2.84 \\
\hline $\mathrm{H}_{2} \mathrm{~T}(\mathrm{iPr}) \mathrm{P}$ & Ruffle & 1.332 & 122.2 & 20.93 & 5.63 & 8.025 & 3.962 & 2.79 & 2.79 \\
\hline $\mathrm{H}_{2} \mathrm{~T}(\mathrm{tBu}) \mathrm{P}$ & Ruffle & 1.334 & 118.1 & 46.52 & 8.43 & 7.831 & 3.8 & 2.68 & 2.68 \\
\hline $\mathrm{H}_{2} 5,10,15$-triNO ${ }_{2}$ ETIOI & Saddle & 1.345 & 128.9 & 2.51 & 8.58 & 8.005 & 3.984 & 2.77 & 2.88 \\
\hline $\mathrm{H}_{2}-5,10,15$-triNO ${ }_{2} \mathrm{OEP}$ & Saddle & 1.346 & 129.2 & 1.45 & 8.84 & 7.974 & 3.993 & 2.74 & 2.92 \\
\hline $\begin{array}{l}\mathrm{H}_{2} 5,10,15,20- \\
\text { tetraNO}\end{array}$ & Saddle & 1.345 & 128.4 & 5.21 & 10.45 & 7.79 & 3.933 & 2.8 & 2.8 \\
\hline $\begin{array}{l}\mathrm{H}_{2} 5,10,15,20- \\
\text { tetraNO}{ }_{2} \mathrm{OEP}\end{array}$ & Saddle & 1.346 & 128.5 & 2.22 & 12.50 & 7.773 & 3.929 & 2.8 & 2.8 \\
\hline $\mathrm{H}_{2} \mathrm{OETPP}$ & Saddle & 1.347 & 122.1 & 2.2 & 17.59 & 7.136 & 3.767 & 2.68 & 2.69 \\
\hline
\end{tabular}


Octaalkylsubstituted porphyrins are essentially planar. As the alkyl groups get larger the core of the porphyrin becomes larger. This is observed in the magnitude of the $\mathrm{D}_{\mathrm{bb}}$ bond lengths which increase from $1.343 \AA$ for $\mathrm{H}_{2} \mathrm{OEP}$ and $\mathrm{H}_{2}$ ETIOI to $1.351 \AA$ for $\mathrm{H}_{2} \mathrm{OIP}$. It is more pronounced when the meso angles $\mathrm{A}_{\mathrm{ama}}$, are measured. It increases form $127.5^{\circ}$ for $\mathrm{H}_{2} \mathrm{OEP}$ to $130.2^{\circ}$ for $\mathrm{H}_{2} \mathrm{OIP}$. $\mathrm{H}_{2} \mathrm{OIP}$ seems to also undergo an unusual type of ruffling. The torsion angle $\mathrm{A}_{\mathrm{rf}}$ increases to $5.2^{\circ}$ but it is not accompanied by smaller $\mathrm{D}_{\mathrm{yz}}$ distance. Ruffling is usually observed with both effects taking place, a larger torsion angle, $A_{\mathrm{rf}}$ and a smaller distance of opposing nitrogens, $D_{\mathrm{xy}}$.

The meso-tetra substituted free-bases show more dramatic effects. Although small differences in structure do seem to exist in $\mathrm{H}_{2} \mathrm{TPP}(8), \mathrm{H}_{2} \mathrm{~T}\left(\mathrm{C}_{6} \mathrm{~F}_{5}\right) \mathrm{P}(12)$, and $\mathrm{H}_{2} \mathrm{~T}(\mathrm{nPe}) \mathrm{P}$ (9), they are also essentially planar. Once the meso-hydrogens are replaced by isopropyl groups then the core becomes smaller due to the ruffling that is taking place. This is particularly evidenced by the $\mathrm{H}_{2}-\mathrm{T}(\mathrm{tBu}) \mathrm{P}(11)$ which has a very pronounced ruffling. It shows meso angles $\mathrm{A}_{\mathrm{ama}}$ to be reducing from $123.7^{\circ}\left(\mathrm{H}_{2} \mathrm{TPP}\right)$ to $117^{\circ}\left(\mathrm{H}_{2}-\mathrm{T}(\mathrm{tBu}) \mathrm{P}\right)$. It also shows very small distances between opposing nitrogens $D_{\text {yz. }}$ Ruffling is evidenced by the improper torsion angle $A_{\mathrm{rf}}$ made by the opposing pyrroles. This angle increases from less than $5^{\circ}$ for the planar porphyrins to $20.93^{\circ}$ for $\mathrm{H}_{2} \mathrm{~T}(\mathrm{iPr}) \mathrm{P}$ and to $46.52^{\circ}$ for $\mathrm{H}_{2} \mathrm{~T}(\mathrm{tBu}) \mathrm{P}$. The $\mathrm{D}_{\mathrm{yz}}$ distance decreases from $2.8 \AA$ or the planar porphyrins to $2.68 \AA$ for the severely ruffled $\mathrm{H}_{2} \mathrm{~T}(\mathrm{tbu}) \mathrm{P}$. This allows the hydrogens to be shared among the central nitrogens, because not only are the nitrogens closer, they are coplanar with the hydrogens. Hydrogen has been shown to stabilize these macrocycles.[31]

For dodecasubstituted porphyrins there is a pronounced interaction between the meso-substituents and the $\beta$-substituents. This prevents ruffling so saddling is observed. 
This is particularly seen for $\mathrm{H}_{2} 5,10,15,20$-tetraNO ${ }_{2} \mathrm{OEP}(18), \mathrm{H}_{2} 5,10,15,20$ -

tetraNO ${ }_{2}$ ETIOI (23) and $\mathrm{H}_{2} \mathrm{OETPP}$ (13). This is evidenced by the $\mathrm{D}_{\text {sd }}$ distance, between $\beta$-carbons of opposite pyrroles and the torsion angle $\left(\mathrm{A}_{\mathrm{sd}}\right)$. The $\mathrm{D}_{\mathrm{sd}}$ distances become smaller and the torsion angle $\mathrm{A}_{\mathrm{sd}}$ increases indicating definite saddling is taking place The amount of saddling increases in the order $\mathrm{H}_{2}-5,10,15$ triNO $\mathrm{ETIOI}_{2} \mathrm{H}_{2}$-triNO $\mathrm{N}_{2} \mathrm{OEP}$, $\mathrm{H}_{2}-5,10,15,20$-tetraNO $\mathrm{O}_{2} \mathrm{OEP}(18) ; \mathrm{H}_{2} 5,10,15,20$-tetraNO ${ }_{2}$ ETIOI (23); $\mathrm{H}_{2} \mathrm{OETPP}$ (13). Interestingly the tetra $\mathrm{NO}_{2}$ substituted porphyrins show significantly larger $\mathrm{D}_{\mathrm{yz}}$ bond distances and a generally expanded core which may be result in less steric interaction between peripheral substituents on the periphery of the macrocycle. These macrocycles have a reduced ability to intramolecularly hydrogen bond since the $\mathrm{N}-\mathrm{H}$ bonds are now further away from the non protonated nitrogens and the hydrogens are not coplanar with the nitrogens.

The partially nitrated octaethylporphyrins and ETIOIporphyrins show increased deformation and show a greater degree of saddling as the meso positions are increasingly substituted. In general the $\mathrm{H}_{2} \mathrm{OEP}$ (5) compounds show more pronounced effects than the ETIOI counterparts. This may be due to the smaller size of the methyl group compared to the ethyl group reducing the $\beta$ and meso group interactions with the substituents in the meso position. The asymmetrically substituted compounds show

differences in the $\mathrm{D}_{z}$ and $\mathrm{D}_{\mathrm{y}}$ distances. In the monosubstituted compound $\mathrm{D}_{\mathrm{z}}$ is greater then the $\mathrm{D}_{\mathrm{y}}$. In the $5,10,15$-triNO $\mathrm{N}_{2}$ compounds it is the $\mathrm{D}_{\mathrm{y}}$ which is greater.

\subsubsection{Dications MM+ and PM3 calculations}

The conformations of the dications were also determined using MM + and PM3 methods (Figures 37-40). It has been well documented that porphyrin dications are 
saddled via X-ray crystal studies [74-77]. Theoretical studies[78, 79] also conclude that the saddled structure is preferred. In both of these types of calculations a counter ion was included in the determination of the most stable structure. The octa- $\beta$-substituted porphyrins exhibit less saddled distortions than the tetra-meso-aryl substituted porphyrins. The tetra-alkyl-meso substituted dications are less saddled and in one case, $\mathrm{H}_{2} \mathrm{~T}(\mathrm{tBu}) \mathrm{P}$ (11) ruffling is observed. The degree of saddling was also found to be dependent on the counter ion of crystallization[80].

In our study no counter ion was included because we wanted to determine only the influence of peripheral substituents. Most of the dications did show a saddled structure but in some cases the saddling was less than expected. The ones that showed the least saddling were the octa- $\beta$-alkyl substituted compounds. These were almost planar as shown in Figure 35. The tetra-meso-aryl substituted porphyrins show definite saddling; however the tetra-meso-alkyl substituted porphyrins tend towards a ruffled structure. This ruffling has been observed using crystal structures, but only preliminary X-ray data is available. Since it is known that having a charged compound will make the modeling methods less accurate and also that the counter ion must be included in order to have meaningful results, we do not believe that these structures are an accurate reflection of what occurs in solution.

\subsubsection{Core energetics}

The strain energy $(\mathrm{MM}+)$ and the heats of formation, $\Delta \mathrm{H}_{\mathrm{f}}(\mathrm{PM} 3)$ of the minimized structures are reported in Table 26-28. 

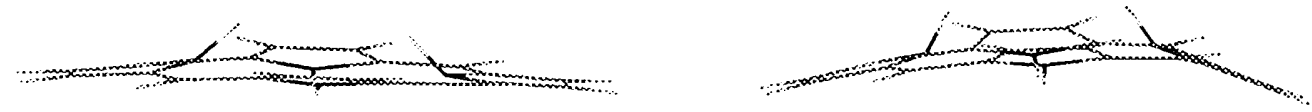

\section{$\mathrm{H}_{4} \mathrm{OEP}^{2+}$}

a

b
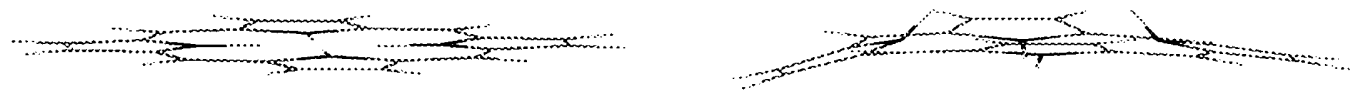

\section{$\mathrm{H}_{4} \mathrm{ETIO}^{2+}$}

a

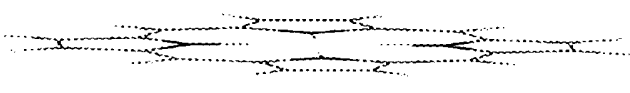

\section{$\mathrm{H}_{4} \mathrm{OIP}^{2+}$}

a

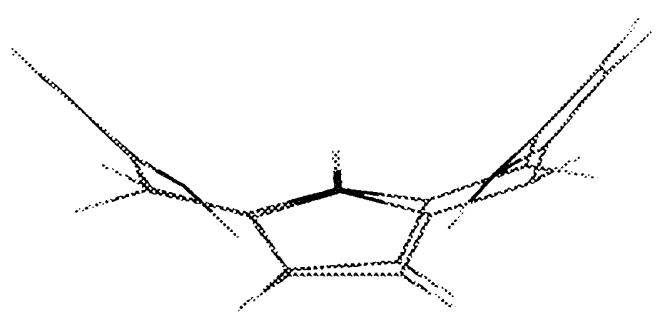

$\mathrm{H}_{4} \mathrm{OETPP}^{2+}$

a b

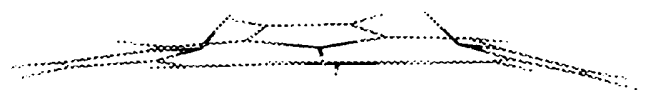

b

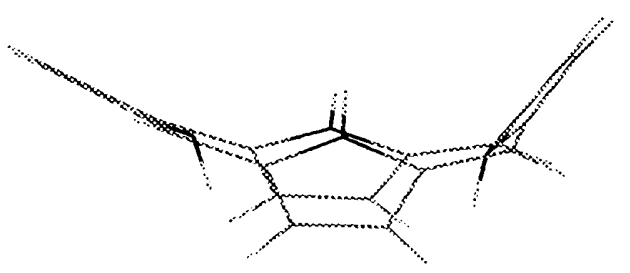

b

Figure 34. Porphyrin dications energy minimized structures obtained from $\mathrm{MM}+(\mathrm{a})$ and PM3 (b) calculations. $\mathrm{H}_{4} \mathrm{OEP}^{2+}(5), \mathrm{H}_{4} \mathrm{ETIOI}^{2+}(6), \mathrm{H}_{4} \mathrm{O}(\mathrm{iPr}) \mathrm{P}^{2+}(7)$ and $\mathrm{H}_{4} \mathrm{OETPP}^{2+}(13)$. 


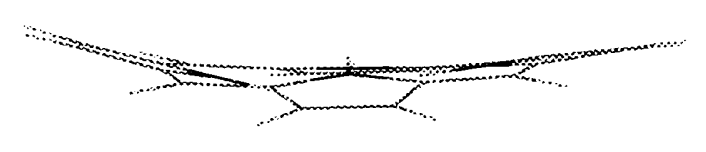

$\mathrm{H}_{4} \mathrm{TPP}^{2+}$

a

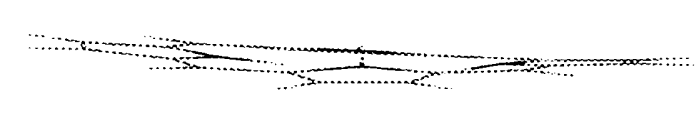

$\mathrm{H}_{4} \mathrm{~T}(\mathrm{nPe}) \mathrm{P}^{2+}$

a

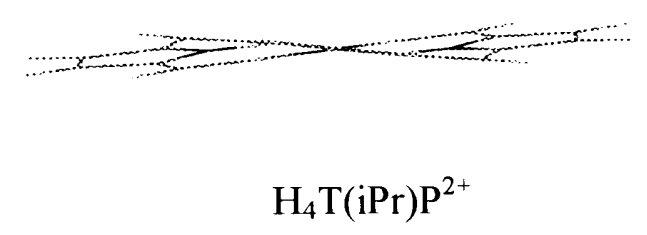

a

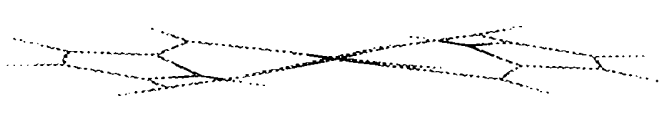

$\mathrm{H}_{4} \mathrm{~T}(\mathrm{tBu}) \mathrm{P}^{2+}$

a

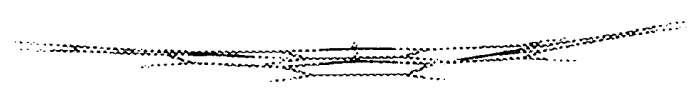

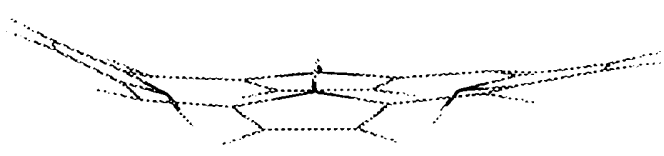

h

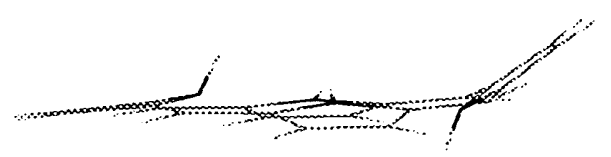

h

h
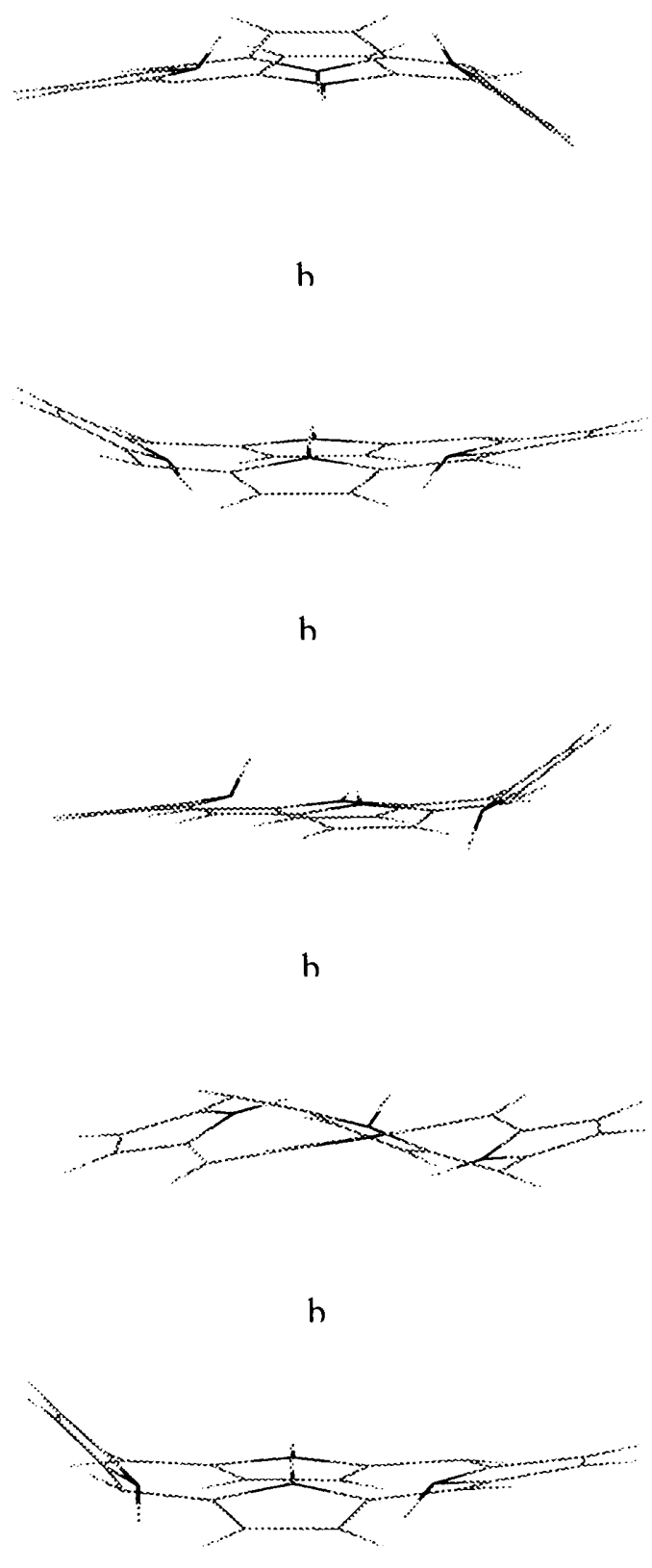

h

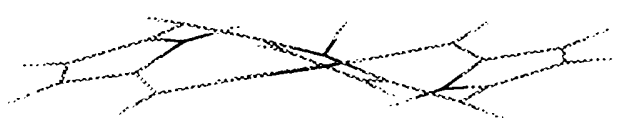

h

\section{$\mathrm{H}_{4} \mathrm{TFP}^{2+}$}

a

Figure 35. Porphyrin dications energy minimized structures obtained from $\mathrm{MM}+$ (a) and PM3 (b) calculations. $\mathrm{H}_{4} \mathrm{TPP}^{2+}(8), \mathrm{H}_{4} \mathrm{~T}(\mathrm{nPe}) \mathrm{P}^{2+}(9), \mathrm{H}_{4} \mathrm{~T}(\mathrm{iPr}) \mathrm{P}^{2+}(10), \mathrm{H}_{4} \mathrm{~T}(\mathrm{tBu}) \mathrm{P}^{2+}(11)$ and $\mathrm{H}_{4} \mathrm{~T}\left(\mathrm{C}_{6} \mathrm{~F}_{5}\right) \mathrm{P}^{2+}(12)$. 


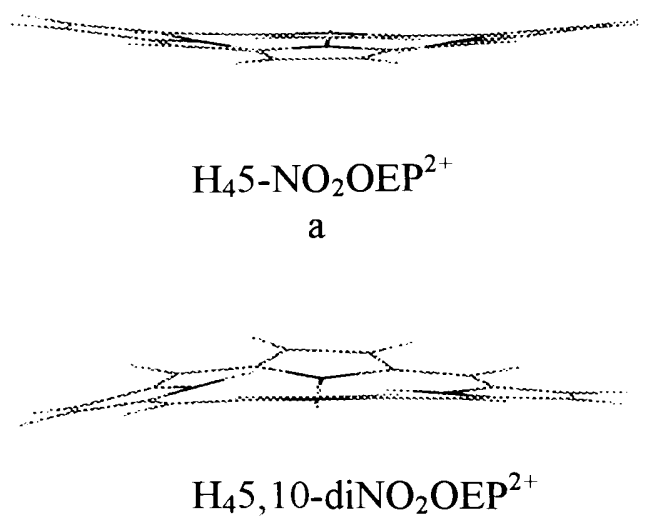

a

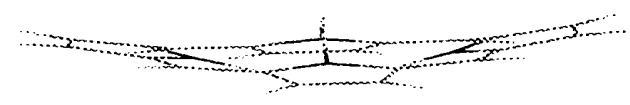

$\mathrm{H}_{4} 5,15-\mathrm{diNO}_{2} \mathrm{OEP}^{2+}$

a

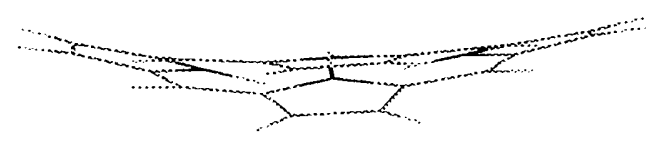

$\mathrm{H}_{4} 5,10,15-$ triNO$_{2} \mathrm{OEP}^{2+}$

a

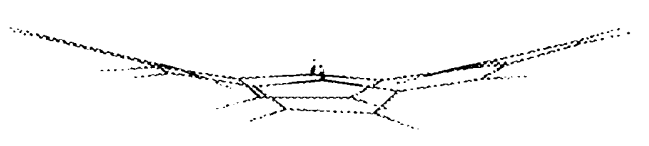

$\mathrm{H}_{4} 5,10,15,20$-tetraNO $\mathrm{OEP}^{2+}$

a

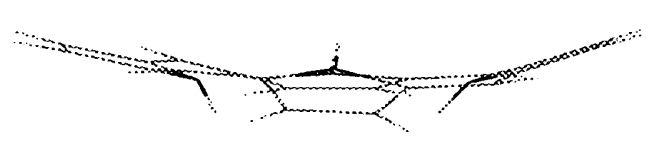

b

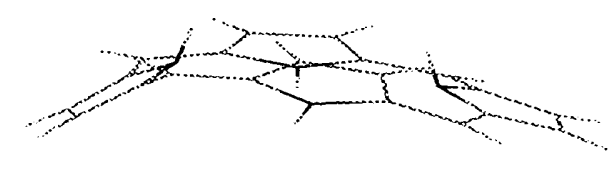

$\mathrm{h}$

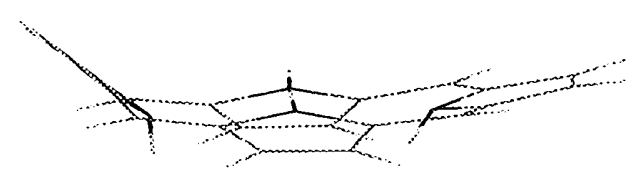

b

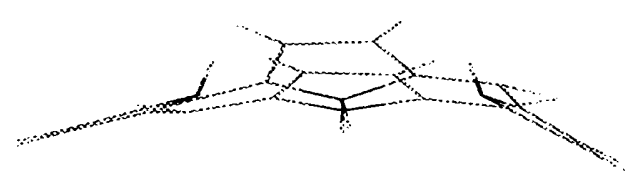

b

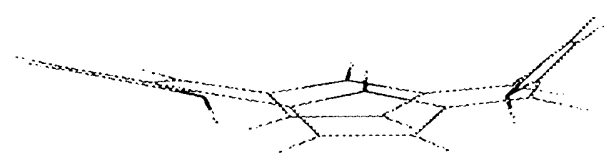

Figure 36. Porphyrin dications energy minimized structures obtained from $\mathrm{MM}+$ (a) and $\mathrm{PM} 3$ (b) calculations. $\mathrm{H}_{4} 5-\mathrm{NO}_{2} \mathrm{OEP}^{2+}(14), \mathrm{H}_{4} 5,15-\mathrm{NO}_{2} \mathrm{OEP}^{2+}(15), \mathrm{H}_{4} 5,10-\mathrm{NO}_{2} \mathrm{OEP}^{2+}$ (16), $\mathrm{H}_{4} 5,10,15-\mathrm{NO}_{2} \mathrm{OEP}^{2+}(17)$ and $\mathrm{H}_{4} 5,10,15,20-\mathrm{NO}_{2} \mathrm{OEP}^{2+}$ (18). 


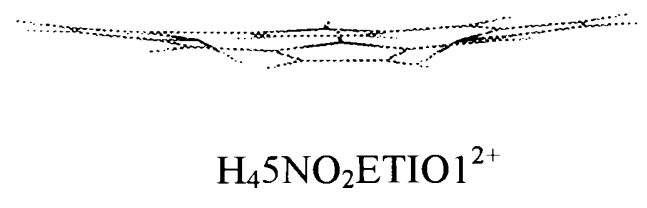

a

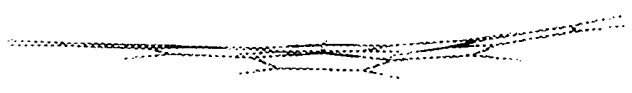

$\mathrm{H}_{4} 5,10-\mathrm{diNO}_{2} \mathrm{ETIO}^{2+}$

a

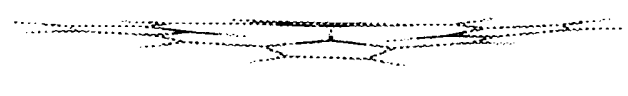

$\mathrm{H}_{4} 5,15-\mathrm{diNO}_{2} \mathrm{ETIO}^{2+}$

a

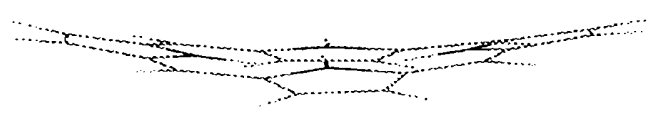

$\mathrm{H}_{4} 5,10,15-$ triNO$_{2} \mathrm{ETIO}^{2+}$

a

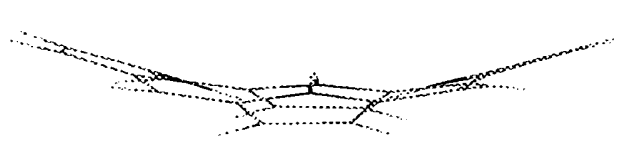

$\mathrm{H}_{4} 5,10,15,20$-tetraNO $\mathrm{ETIO}^{2+}$

a

b

Figure 37. Porphyrin dications energy minimized structures obtained from $\mathrm{MM}+(\mathrm{a})$ and PM3 (b) calculations. $\mathrm{H}_{4} 5-\mathrm{NO}_{2} \mathrm{ETIOI}^{2+}(19), \mathrm{H}_{4} 5,15-\mathrm{NO}_{2} \mathrm{ETIOI}^{2+}(20), \mathrm{H}_{4} 5,10-$ $\mathrm{NO}_{2} \mathrm{ETIOI}^{2+}(21), \mathrm{H}_{4} 5,10,15-\mathrm{NO}_{2} \mathrm{ETIOI}^{2+}(22)$ and $\mathrm{H}_{4} 5,10,15,20-\mathrm{NO}_{2} \mathrm{ETIOI}^{2+}$ (23). 


\subsubsection{Free base porphyrins $\mathrm{PM} 3 / / \mathrm{MM}+$ and $\mathrm{B} 3 \mathrm{LYP} / 6-31 \mathrm{G} / / \mathrm{MM}+$ calculations}

The strain energy reported from the $\mathrm{MM}+$ studies must be corrected to be meaningful. In order to compare to experimental data obtained in calorimetry, two single point energy calculations were carried out, one using PM3 (PM3//MM+) and another using B3LYP $(\mathrm{BLY} 3 \mathrm{P} / / \mathrm{MM}+)$. These are also reported in Table 26-28

We wanted to calculate differences in the energies which result from deformation of the macrocycle from planarity, and not that due to the presence of different substituents therefore all of the substituents were replaced by hydrogens and the $\mathrm{C}-\mathrm{H}$ bonds in the periphery were allowed to relax using $\mathrm{MM}+$. The macrocyclic conformation was frozen and not allowed to change. Single point energies of the optimized structures obtained from $\mathrm{MM}+$ were again obtained using PM3 and B3LYP.

These energies correspond to those of porphine free-base adopting the macrocyclic conformation of the particular porphyrin. The energy calculated for the planar $\mathrm{H}_{2} \mathrm{OEP}$ (5) was subtracted from each of the free-bases. This is called the energy of Energy of deformation from planarity. $\mathrm{H}_{2} \mathrm{OEP}(5)$ was taken as a reference because calorimetric studies were not possible to execute using porphine as a reference as a result of its insolubility. These data are all reported in Tables 26-28 
Table 26. Energies calculated using different models for each free-base porphyrin, macrocyclic portion and relative to the $\mathrm{H}_{2} \mathrm{OEP}$ conformation.

\begin{tabular}{|c|c|c|c|c|}
\hline Free-base & $\begin{array}{l}\Delta \mathrm{E}_{\text {molecule }}{ }^{\mathrm{a}} \\
(\mathrm{kcal} / \mathrm{mole})\end{array}$ & $\begin{array}{l}\Delta \mathrm{E}_{\text {coreb }} \\
\text { (kcal/mole) }\end{array}$ & $\begin{array}{l}\Delta \mathrm{E}_{\text {core def }}{ }^{\mathrm{c}} \\
(\mathrm{kcal} / \mathrm{mole})\end{array}$ & Core conformation \\
\hline $\begin{array}{rr}\mathrm{H}_{2} \mathrm{OEP} & \mathrm{MM}+ \\
\mathrm{PM} 3 \mathrm{RHF} \\
\mathrm{PM} 3 / \mathrm{MM}+ \\
\mathrm{B} 3 \mathrm{LYP} / 6-31 \mathrm{G}^{*}\end{array}$ & $\begin{array}{l}50.51 \\
70.65 \\
61.68 \\
61.68\end{array}$ & $\begin{array}{l}61.5 \\
187.57 \\
339.62 \\
-620489.30\end{array}$ & $\begin{array}{l}0 \\
0 \\
0 \\
0\end{array}$ & Planar \\
\hline $\begin{array}{rr}\mathrm{H}_{2} \text { ETIOI } & \mathrm{MM}+ \\
\mathrm{PM} 3 \mathrm{RHF} \\
\mathrm{PM} 3 / \mathrm{MM}+ \\
\text { B3LYP/MM+ }\end{array}$ & $\begin{array}{l}48.06 \\
90.91 \\
58.63 \\
58.63 \\
\end{array}$ & $\begin{array}{l}61.43 \\
187.56 \\
339.81 \\
-620488.87 \\
\end{array}$ & $\begin{array}{l}-0.07 \\
-0.01 \\
0.19 \\
0.43 \\
\end{array}$ & Planar \\
\hline $\begin{array}{rr}\mathrm{H}_{2} \mathrm{O} \text { (iPr)P } \mathrm{P} \\
\mathrm{MM}+ \\
\mathrm{PM} 3 \mathrm{RHF} \\
\mathrm{PM} 3 / \mathrm{MM}+ \\
\mathrm{B} 3 \mathrm{LYP} / \mathrm{MM}+ \\
\end{array}$ & $\begin{array}{l}83.17 \\
29.82 \\
65.37 \\
65.37 \\
\end{array}$ & $\begin{array}{l}65.37 \\
188.0 \\
345.73 \\
-620491.39\end{array}$ & $\begin{array}{l}3.87 \\
0.43 \\
6.11 \\
-2.09\end{array}$ & Planar \\
\hline $\begin{array}{rr}\mathrm{H}_{2} \mathrm{TPP} & \mathrm{MM}+ \\
\mathrm{PM} 3 \mathrm{RHF} \\
\mathrm{PM} 3 / \mathrm{MM}+ \\
\text { B3LYP/MM+ }\end{array}$ & $\begin{array}{l}124.84 \\
296.52 \\
63.09 \\
63.09\end{array}$ & $\begin{array}{l}63.09 \\
187.59 \\
347.62 \\
-620484.44\end{array}$ & $\begin{array}{l}1.59 \\
0.02 \\
8.0 \\
4.86\end{array}$ & Planar \\
\hline $\begin{array}{r}\mathrm{H}_{2} \mathrm{~T}(\mathrm{nPe}) \mathrm{P} \\
\mathrm{MM}+ \\
\mathrm{PM} 3 \mathrm{RHF} \\
\mathrm{PM} 3 / \mathrm{MM}+ \\
\mathrm{B} 3 \mathrm{LYP} / \mathrm{MM}+\end{array}$ & $\begin{array}{l}76.1 \\
75.26 \\
61.59 \\
61.59 \\
\end{array}$ & $\begin{array}{l}61.59 \\
188.09 \\
348.44 \\
-620484.69\end{array}$ & $\begin{array}{l}-0.09 \\
0.52 \\
8.82 \\
4.61 \\
\end{array}$ & Planar \\
\hline $\begin{array}{r}\mathrm{H}_{2} \mathrm{~T} \text { (iPr)P } \mathrm{MM}+ \\
\mathrm{PM} 3 \mathrm{RHF} \\
\mathrm{PM} / \mathrm{MM}+ \\
\text { B3LYP/MM+ }\end{array}$ & $\begin{array}{l}103.08 \\
125.16 \\
68.77 \\
68.77\end{array}$ & $\begin{array}{l}68.77 \\
189.04 \\
350.86 \\
-620478.32\end{array}$ & $\begin{array}{l}7.27 \\
1.47 \\
11.24 \\
10.98\end{array}$ & Ruffled \\
\hline $\begin{array}{r}\mathrm{H}_{2} \mathrm{~T}(\mathrm{tBu}) \mathrm{P} \\
\mathrm{MM}+ \\
\mathrm{PM} 3 \mathrm{RHF} \\
\mathrm{PM} / \mathrm{MM}+ \\
\mathrm{B} 3 \mathrm{LYP} / \mathrm{MM}+ \\
\end{array}$ & $\begin{array}{l}158.90 \\
131.90 \\
94.55 \\
94.55 \\
\end{array}$ & $\begin{array}{l}94.55 \\
213.15 \\
358.76 \\
-620449.30 \\
\end{array}$ & $\begin{array}{l}33.05 \\
25.58 \\
19.14 \\
40 \\
\end{array}$ & Ruffled \\
\hline $\begin{array}{r}\mathrm{H}_{2} \mathrm{~T}\left(\mathrm{nC}_{5} \mathrm{~F}_{5}\right) \mathrm{P} \\
\mathrm{MM}+ \\
\mathrm{PM} 3 \mathrm{RHF} \\
\mathrm{PM} 3 / \mathrm{MM}+ \\
\mathrm{B} 3 \mathrm{LYP} / \mathrm{MM}+\end{array}$ & $\begin{array}{l}123.99 \\
-533.30 \\
63.08 \\
63.08\end{array}$ & $\begin{array}{l}63.08 \\
187.72 \\
347.64 \\
-620484.45\end{array}$ & $\begin{array}{l}1.58 \\
0.15 \\
8.02 \\
4.85 \\
\end{array}$ & Planar \\
\hline $\begin{array}{r}\mathrm{H}_{2} 5,10,15,20-\mathrm{NO}_{2} \mathrm{OEP} \\
\mathrm{MM}+ \\
\mathrm{PM} 3 \mathrm{RHF} \\
\mathrm{PM} / \mathrm{MM}+ \\
\mathrm{B} 3 \mathrm{LYP} / \mathrm{MM}+\end{array}$ & $\begin{array}{l}92.15 \\
94.22 \\
80.72 \\
80.72\end{array}$ & $\begin{array}{l}81.91 \\
211.52 \\
361.28 \\
-620461.49\end{array}$ & $\begin{array}{l}20.41 \\
23.95 \\
21.66 \\
27.81\end{array}$ & Saddled \\
\hline
\end{tabular}


Table 27. Energies calculated using different models for each free-base porphyrin, the macrocyclic portion and relative to the $\mathrm{H}_{2} \mathrm{OEP}$ conformation

\begin{tabular}{|c|c|c|c|c|}
\hline Free-base & \begin{tabular}{|l|l|}
$\Delta \mathrm{E}_{\text {molecule }}$ \\
$(\mathrm{kcal} / \mathrm{mole})$
\end{tabular} & $\begin{array}{l}\Delta \mathrm{E}_{\text {core }} \\
\text { (kcal/mole) }\end{array}$ & $\begin{array}{l}\Delta \mathrm{E}_{\text {core def }} \\
(\mathrm{kcal} / \mathrm{mole})\end{array}$ & \\
\hline \multicolumn{5}{|l|}{$\mathrm{H}_{2} \mathrm{OEP}$} \\
\hline $\mathrm{MM}+$ & 50.51 & 61.68 & 0 & Planar \\
\hline PM3 RHF & 70.65 & 187.57 & 0 & \\
\hline $\mathrm{PM} 3 / \mathrm{MM}+$ & 61.68 & 339.62 & 0 & \\
\hline B3LYP/6-31G*//MM+ & 61.68 & -620489.30 & 0 & \\
\hline \multicolumn{5}{|l|}{$\mathrm{H}_{2} 5-\mathrm{NO}_{2} \mathrm{OEP}$} \\
\hline $\mathrm{MM}+$ & 48.43 & 62.55 & 0.87 & Planar \\
\hline PM3 RHF & 74.98 & 192.75 & 5.18 & \\
\hline $\mathrm{PM} 3 / \mathrm{MM}+$ & 62.55 & 345.81 & 13.52 & \\
\hline B3LYP/6-31G*//MM+ & 62.55 & -620489.54 & -0.24 & \\
\hline \multicolumn{5}{|l|}{$\mathrm{H}_{2} 5,10-\mathrm{diNO}_{2} \mathrm{OEP}$} \\
\hline $\mathrm{MM}+$ & 59.92 & 67.19 & 21.73 & Planar \\
\hline PM3 RHF & 81.87 & 200.19 & 12.62 & \\
\hline PM3/MM+ & 67.19 & 346.31 & 15.47 & \\
\hline B3LYP/6-31G*//MM+ & 67.19 & -620484.26 & 5.04 & \\
\hline \multicolumn{5}{|l|}{$\mathrm{H}_{2} 5,15-\mathrm{diNO}_{2} \mathrm{OEP}$} \\
\hline MM+ & 87.14 & 67.04 & 5.54 & Planar \\
\hline PM3 RHF & 79.82 & 196.24 & 8.67 & \\
\hline PM3/MM+ & 67.04 & 343.16 & 3.54 & \\
\hline B3LYP/6-31G*//MM+ & 67.04 & -620489.56 & -0.26 & \\
\hline \multicolumn{5}{|l|}{$\mathrm{H}_{2} 5,10,15$-triNO ${ }_{2} \mathrm{OEP}$} \\
\hline $\mathrm{MM}+$ & 114.11 & 80.79 & 13.3 & Saddled \\
\hline PM3 RHF & 84.73 & 206.63 & 19.06 & \\
\hline PM3/MM+ & 80.79 & 350.3 & 10.68 & \\
\hline B3LYP/6-31G*//MM+ & 80.79 & -620473.6 & 15.74 & \\
\hline \multicolumn{5}{|l|}{$\mathrm{H}_{2} 5,10,15,20$-tetraNO $\mathrm{N}_{2} \mathrm{OEP}$} \\
\hline $\mathrm{MM}+$ & 128.11 & 81.91 & 20.41 & Saddled \\
\hline PM3 RHF & 94.22 & 211.52 & 23.95 & \\
\hline PM3/MM+ & 81.91 & 362.09 & 22.47 & \\
\hline B3LYP/6-31G*//MM+ & 81.91 & -620461.49 & 27.81 & \\
\hline
\end{tabular}


Table 28. Energies calculated using different models for each free-base porphyrin, the macrocyclic portion and relative to the $\mathrm{H}_{2} \mathrm{OEP}$ conformation

\begin{tabular}{|c|c|c|c|c|}
\hline Free-base & $\begin{array}{l}\Delta \mathrm{E}_{\text {molecule }} \\
(\mathrm{kcal} / \mathrm{mole})\end{array}$ & $\begin{array}{l}\Delta \mathrm{E}_{\text {core }} \\
(\mathrm{kcal} / \mathrm{mole})\end{array}$ & $\begin{array}{l}\Delta \mathrm{E}_{\text {core def }} \\
(\mathrm{kcal} / \mathrm{mole})\end{array}$ & \\
\hline $\mathrm{H}_{2} \mathrm{ETIOI}$ & & & & \multirow{4}{*}{ Planar } \\
\hline $\mathrm{MM}+$ & 48.06 & $6 \mathrm{I} .43$ & -0.07 & \\
\hline PM3 RHF & 90.91 & 187.56 & -0.01 & \\
\hline PM3/MM+ & 58.63 & 339.81 & 0.19 & \\
\hline $\mathrm{H}_{2} 5-\mathrm{NO}_{2}$ ETIOI & & & & \multirow{4}{*}{ Planar } \\
\hline $\mathrm{MM}+$ & 64.98 & 63.56 & 2.06 & \\
\hline PM3 RHF & 94.09 & 190.90 & 3.34 & \\
\hline PM3/MM+ & 65.04 & 346.66 & 7.04 & \\
\hline $\mathrm{H}_{2} 5,10$-diNO 2 ETIOI & & & & \multirow{4}{*}{ Planar } \\
\hline $\mathrm{MM}+$ & 82.28 & 66.24 & 4.74 & \\
\hline PM3 RHF & 97.83 & 199.11 & 11.55 & \\
\hline PM3/MM+ & 64.46 & 347.1 & 7.48 & \\
\hline $\mathrm{H}_{2} 5,15-\mathrm{diNO}_{2} \mathrm{ETIOI}$ & & & & \multirow{4}{*}{ Planar } \\
\hline $\mathrm{MM}+$ & 82.36 & 65.91 & 4.41 & \\
\hline PM3 RHF & 98.77 & 195.05 & 7.48 & \\
\hline PM3/MM+ & 65.21 & 343.1 & 3.48 & \\
\hline $\mathrm{H}_{2} 5,10,15$-triNO ${ }_{2}$ ETIOI & & & & \multirow{4}{*}{ Saddled } \\
\hline $\mathrm{MM}+$ & 102.1 & 71.77 & 10.27 & \\
\hline PM3 RHF & 106.03 & 203.23 & 15.67 & \\
\hline PM3/MM+ & 64.80 & 350.26 & 10.64 & \\
\hline $\mathrm{H}_{2} 5,10,15,20$-tetraNO ${ }_{2}$ ETIOI & & & & \multirow{4}{*}{ Saddled } \\
\hline $\mathrm{MM}+$ & 114.23 & 78.48 & 16.98 & \\
\hline PM3 RHF & 111.32 & 209.31 & 21.75 & \\
\hline PM3/MM+ & 69.35 & 359.59 & 19.97 & \\
\hline
\end{tabular}




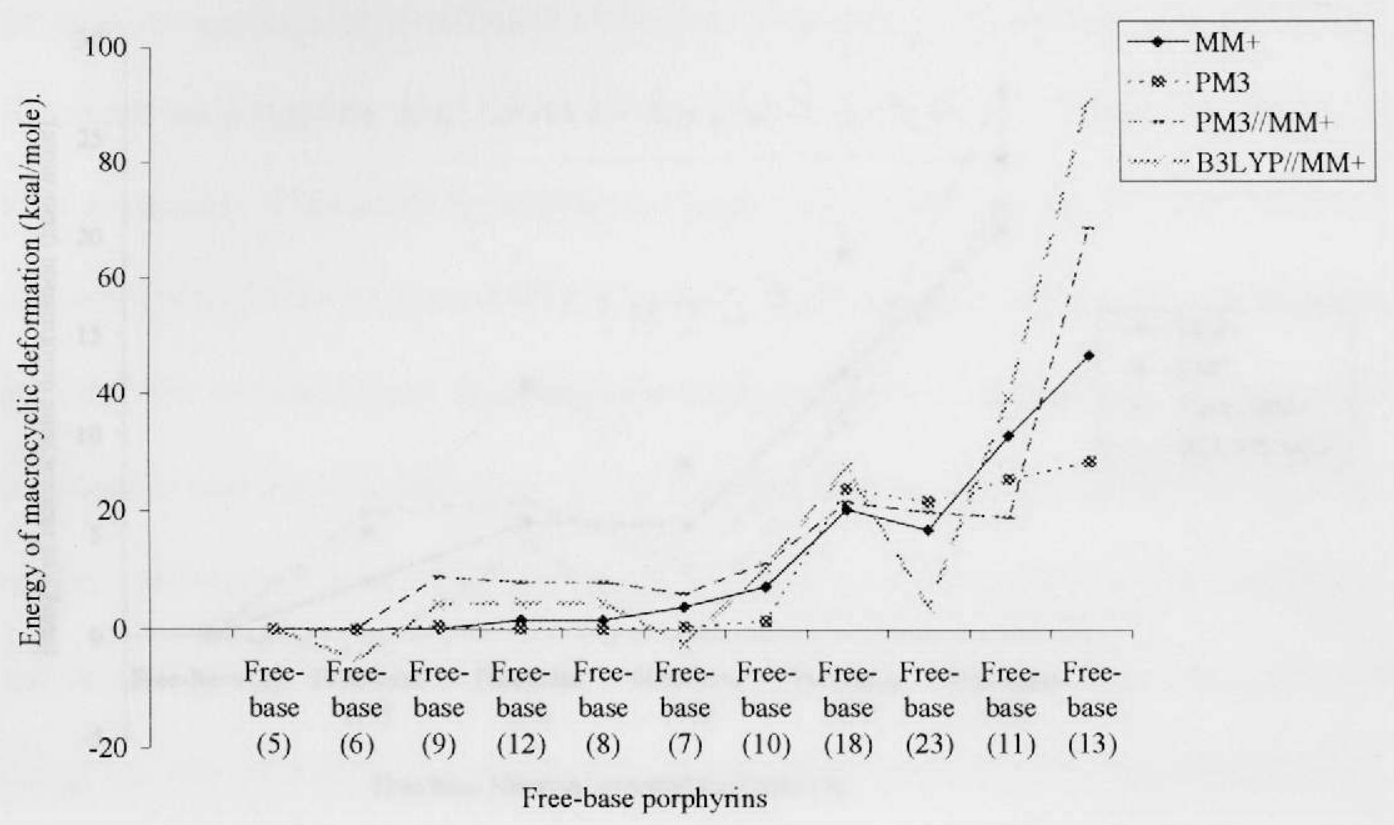

Graph 1 - Energy of deformation calculated using four different methods. Only symmetrically substituted porphyrins shown.

Energy of macrocyclic deformation versus Nitrated etioporphyrin I (6)

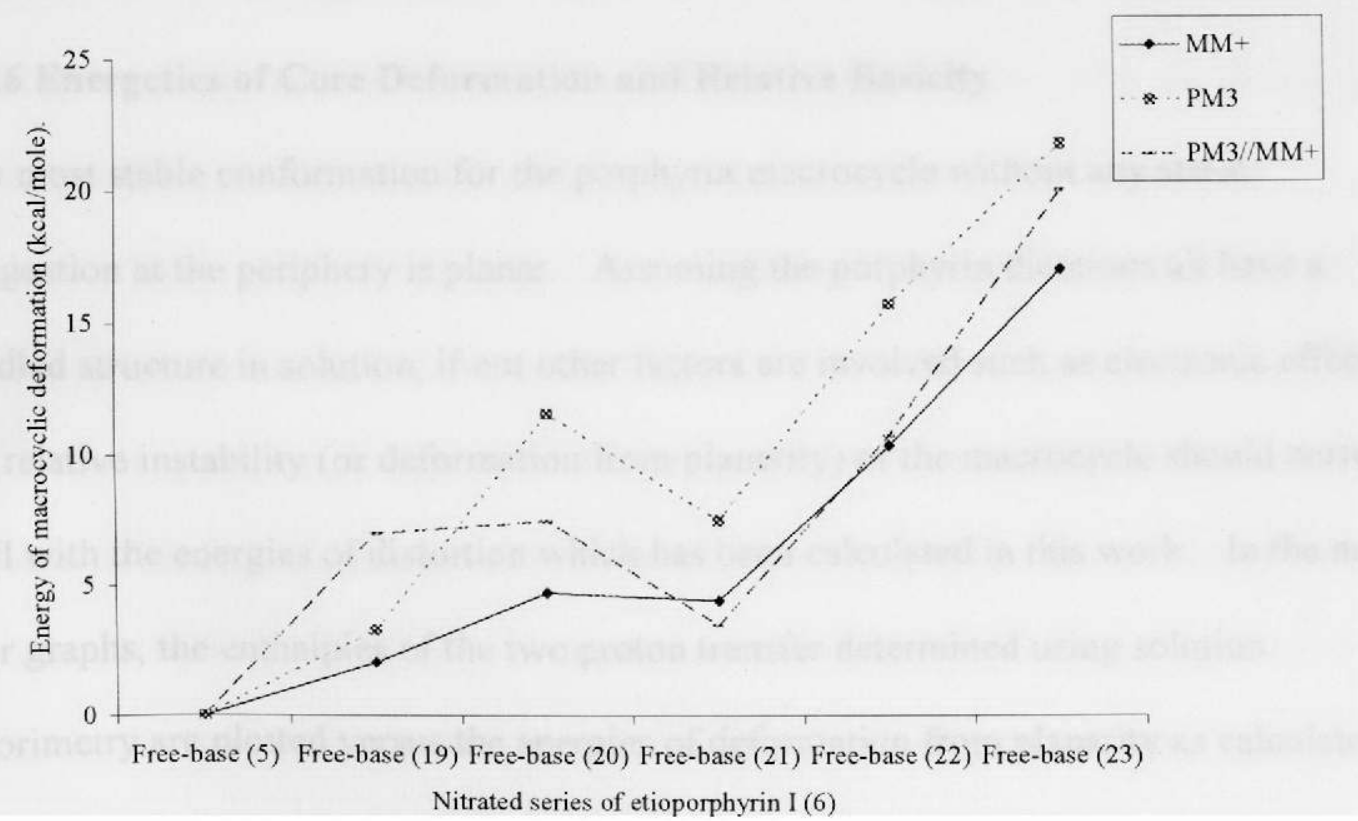

Graph 2 - Energy of deformation calculated using three different methods. Nitrated products of $\mathrm{H}_{2} \mathrm{ETIOI}(6)$. 


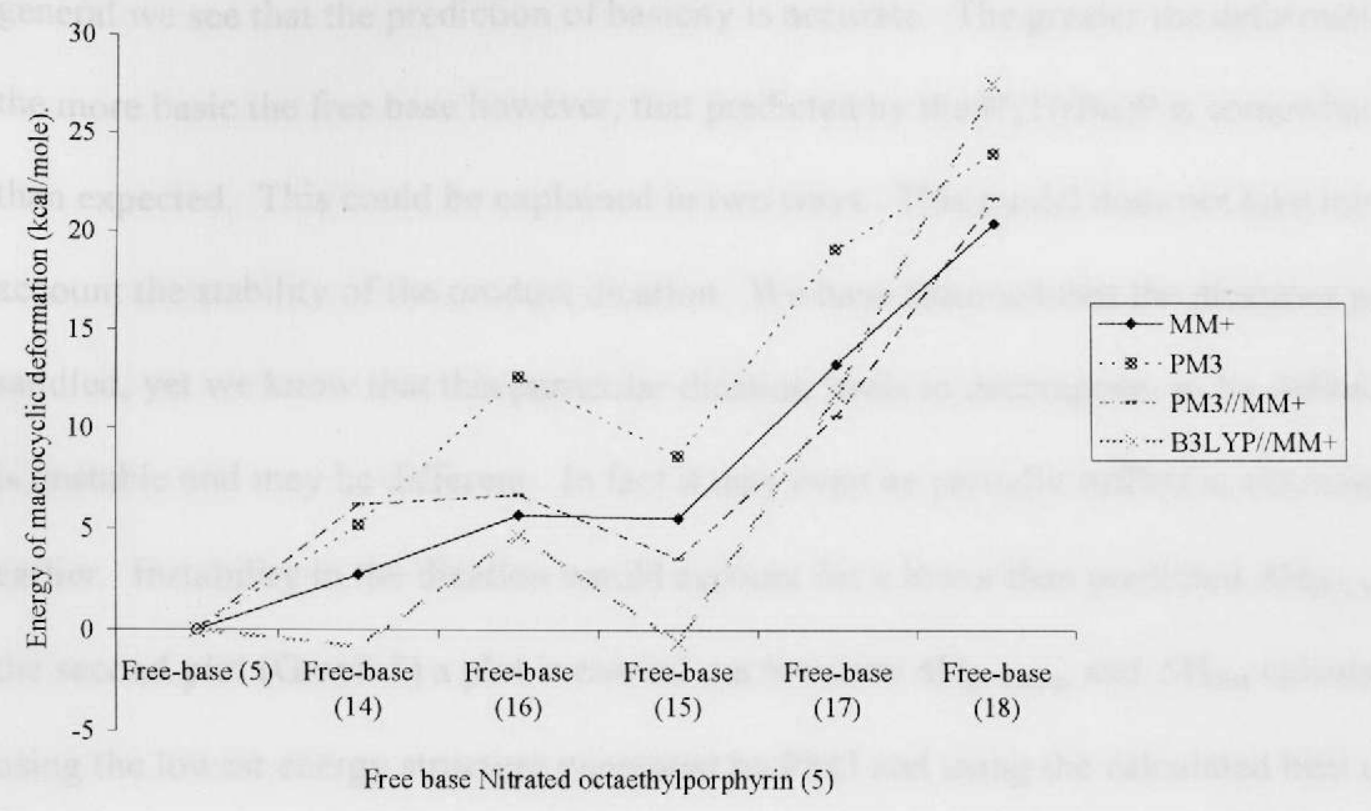

Graph 3 - Energy of deformation calculated using four different methods. Nitrated products of $\mathrm{H}_{2} \mathrm{OEP}$

\subsubsection{Energetics of Core Deformation and Relative Basicity}

The most stable conformation for the porphyrin macrocycle without any steric congestion at the periphery is planar. Assuming the porphyrin dications all have a saddled structure in solution, if not other factors are involved such as electronic effects, the relative instability (or deformation from planarity) of the macrocycle should correlate well with the energies of distortion which has been calculated in this work. In the next four graphs, the enthalpies of the two proton transfer determined using solution calorimetry are plotted versus the energies of deformation from planarity as calculated. This is done only for the free-base porphyrins with relatively similar electron withdrawing groups. In the first graph (Graph 4) $\Delta \mathrm{H}_{\text {prot trans }}$ is plotted versus the energy 
of macrocyclic distortion calculated from the lowest energy structure using $\mathrm{MM}+$. In general we see that the prediction of basicity is accurate. The greater the deformation, the more basic the free base however, that predicted by the $\mathrm{H}_{2} \mathrm{~T}(\mathrm{tBu}) \mathrm{P}$ is somewhat lower than expected. This could be explained in two ways. This model does not take into account the stability of the product dication. We have assumed that the dications are all saddled, yet we know that this particular dication tends to decompose, so by definition it is unstable and may be different. In fact it may even be partially ruffled as discussed earlier. Instability in the dication would account for a lower than predicted $\Delta \mathrm{H}_{\text {prot trans. In }}$ the second plot (Graph 5) a plot is carried out between $\Delta \mathrm{H}_{\text {prot trans }}$ and $\Delta \mathrm{H}_{\text {dist }}$ calculated using the lowest energy structure generated by PM3 and using the calculated heat of formation using PM3. Very similar behavior is observed. This was somewhat surprising considering the structures which were obtained somehow did not seem "correct". A third method was used in which the MM+ minimized macrocycle was subjected to a single point energy calculation using PM3 (PM3/MM+). Graph 6 plots the $\Delta \mathrm{H}_{\text {prot.trans. }}$ versus the energy of deformation calculated using this method. This shows an essentially linear plot with two outlying points. The points are those of $\mathrm{H}_{2} \mathrm{ETIOI}$ and $\mathrm{H}_{2} \mathrm{OIP}$. These are the ones we believe are affected by the stability of the dications. The $\mathrm{H}_{2} \mathrm{OIP}$ has a greater steric bulk at the $\beta$ substituents therefore requires more of a saddling of the dication than other structures. This will make it more unstable and therefore decrease its basicity. The $\mathrm{H}_{2}$ ETIOI should not have this problem and indeed may be able to choose the most stable dication structure. This would account for it having a greater basicity than was predicted. A better study of the energetics of the dicationic structures is planned to resolve this issue. 
In graph 7 a plot is made of $\Delta H_{\text {prot.trans. }}$ versus energy of deformation using density functional methods (BL3LYP//MM+). The correlation only improves. Indeed this model even predicts the location of the $\mathrm{H}_{2} \mathrm{OIP}$. The only point that is outlying is the $\mathrm{H}_{2}$ ETIOI. This may be due to the explanations we gave before that the dication of this molecule is much freer to adopt the most stable conformation possible. The differences are due to the stability of the dications rather than the instability of the free base.

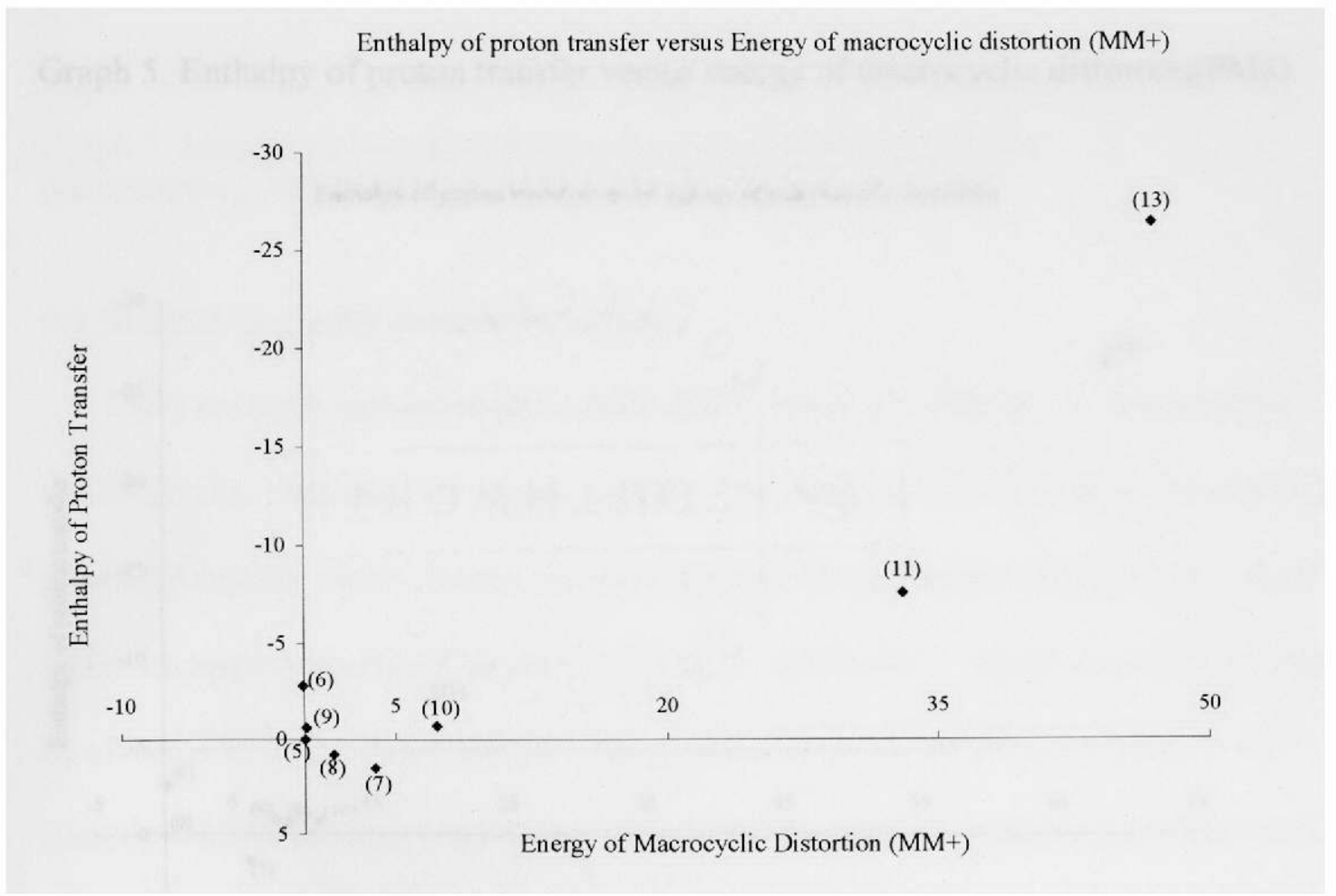

Graph 4 .Enthalpy of proton transfer versus energy of macrocyclic distortion(MM+). 


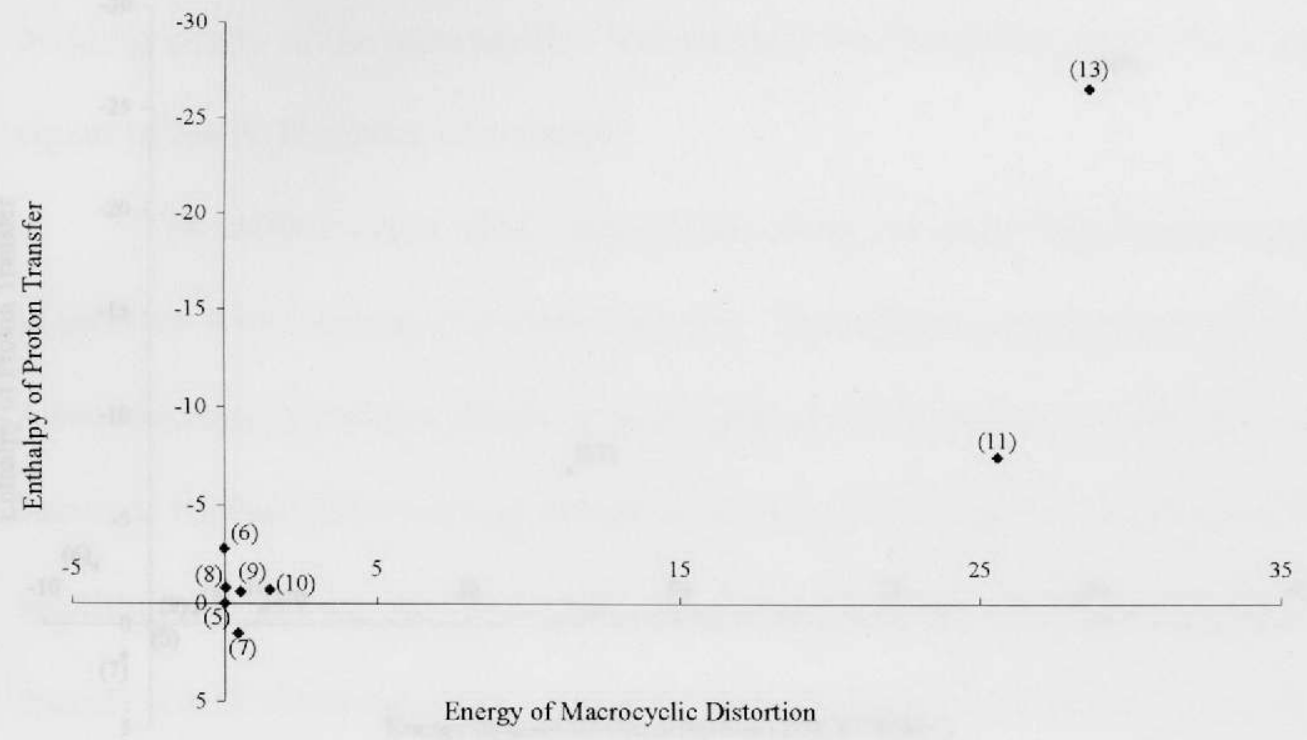

Graph 5. Enthalpy of proton transfer versus energy of macrocyclic distortion(PM3).

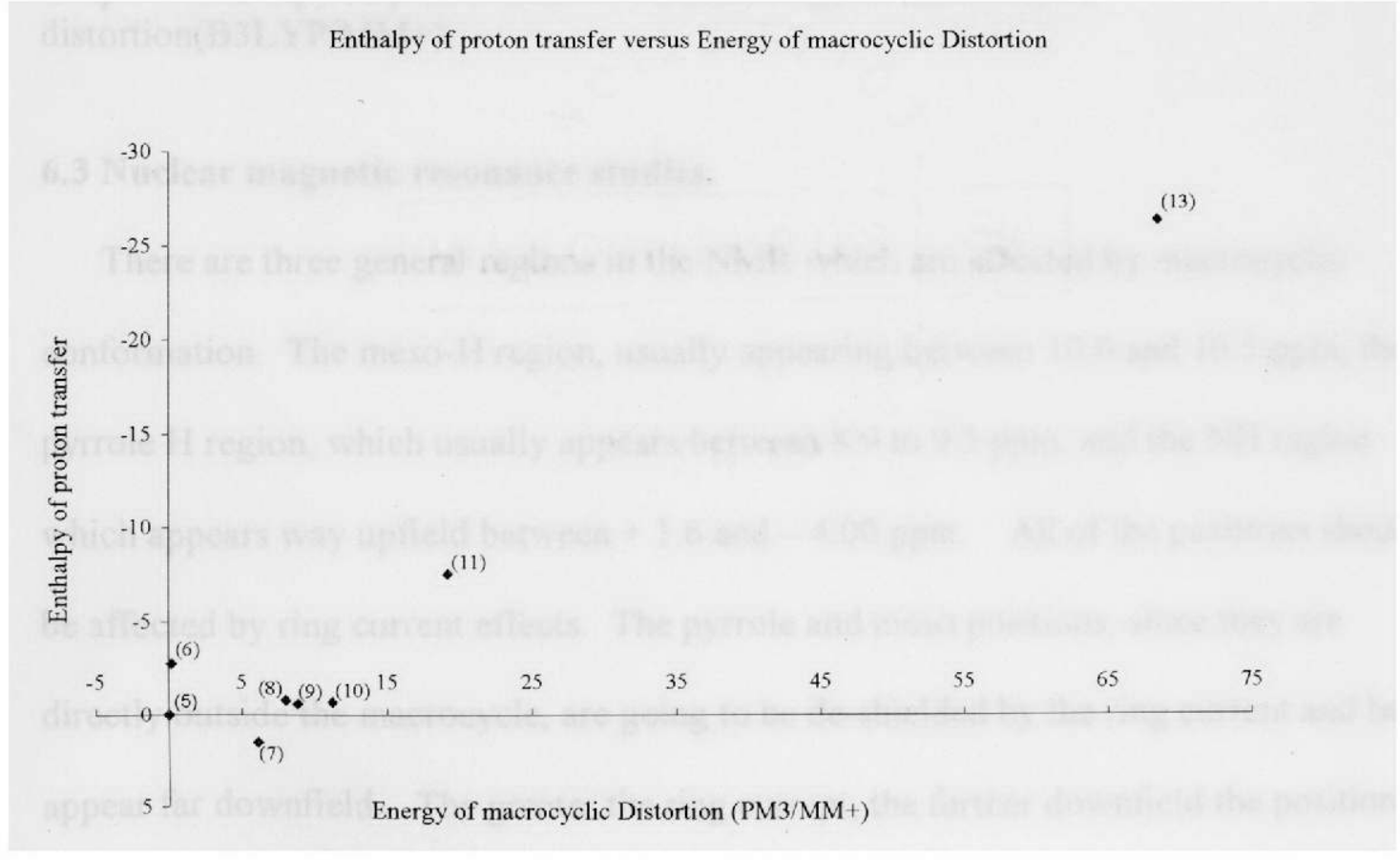

Graph 6. Enthalpy of proton transfer versus energy of macrocyclic distortion $(\mathrm{PM} 3 / \mathrm{MM}+)$. 


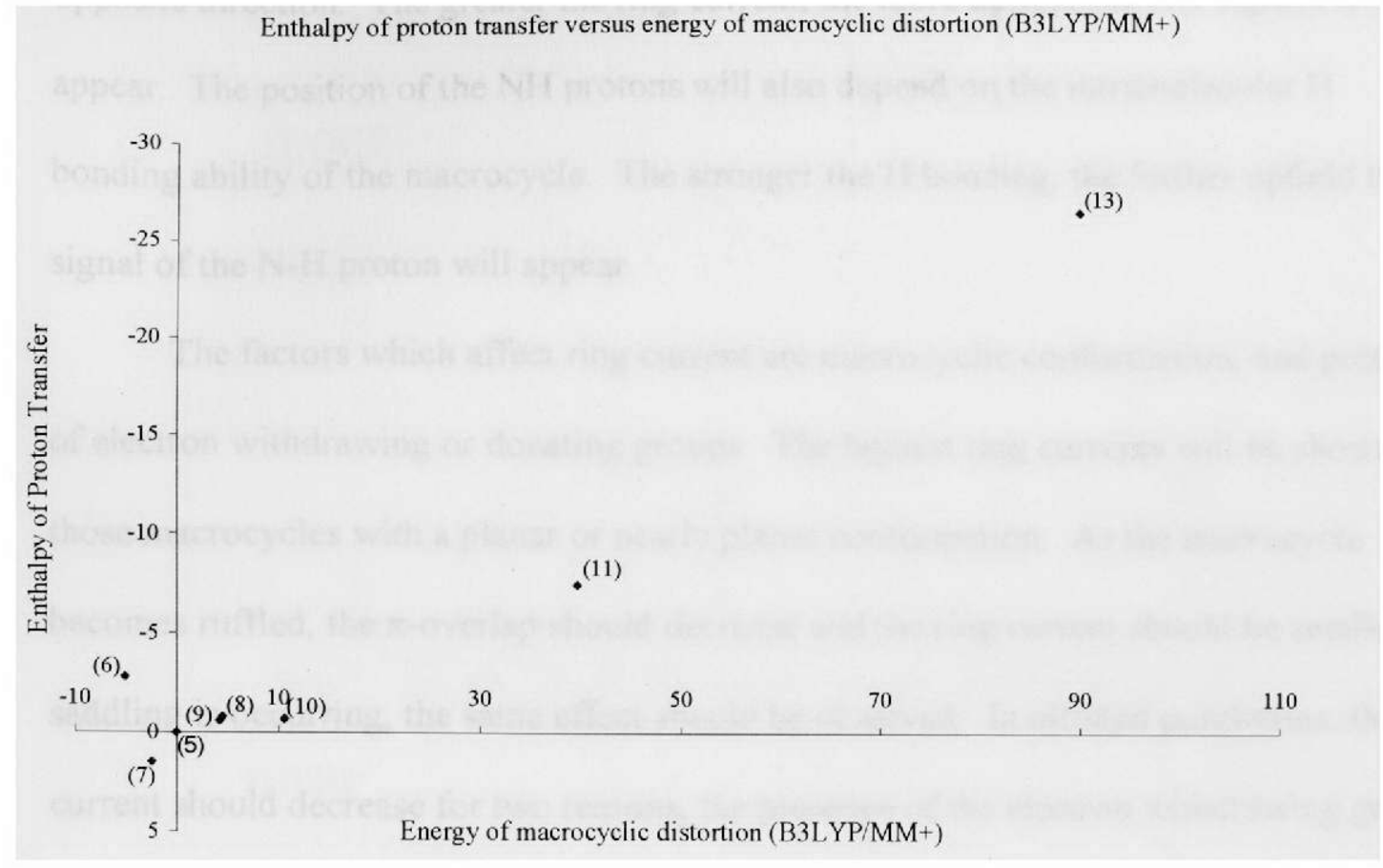

Graph 7. Enthalpy of proton transfer versus energy of macrocyclic distortion $\left(\mathrm{B} 3 \mathrm{LYP} / \mathrm{MM}^{+}\right)$.

\subsection{Nuclear magnetic resonance studies.}

There are three general regions in the NMR which are affected by macrocyclic conformation. The meso-H region, usually appearing between 10.0 and $10.5 \mathrm{ppm}$; the pyrrole $\mathrm{H}$ region, which usually appears between 8.9 to $9.5 \mathrm{ppm}$; and the $\mathrm{NH}$ region which appears way upfield between +1.6 and $-4.00 \mathrm{ppm}$. All of the positions should be affected by ring current effects. The pyrrole and meso positions, since they are directly outside the macrocycle, are going to be de-shielded by the ring current and hence appear far downfield. The greater the ring current, the further downfield the position of the proton signal. The NH protons, will also experience ring current shifts, but in the 
opposite direction. The greater the ring current, the more upfield the NH signals will appear. The position of the $\mathrm{NH}$ protons will also depend on the intramolecular $\mathrm{H}$ bonding ability of the macrocycle. The stronger the $\mathrm{H}$ bonding, the further upfield the signal of the N-H proton will appear.

The factors which affect ring current are macrocyclic conformation, and presence of electron withdrawing or donating groups. The highest ring currents will be shown by those macrocycles with a planar or nearly planar conformation. As the macrocycle becomes ruffled, the $\pi$-overlap should decrease and the ring current should be smaller. If saddling is occurring, the same effect should be observed. In nitrated porphyrins, the ring current should decrease for two reasons, the presence of the electron withdrawing groups, and any macrocyclic distortion from planarity. In Figure 39 there are NMR spectra of three representative porphyrins. Additionally in Figures 40 the NMR spectra of the nitrated $\mathrm{H}_{2} \mathrm{OEP}$ are presented. 

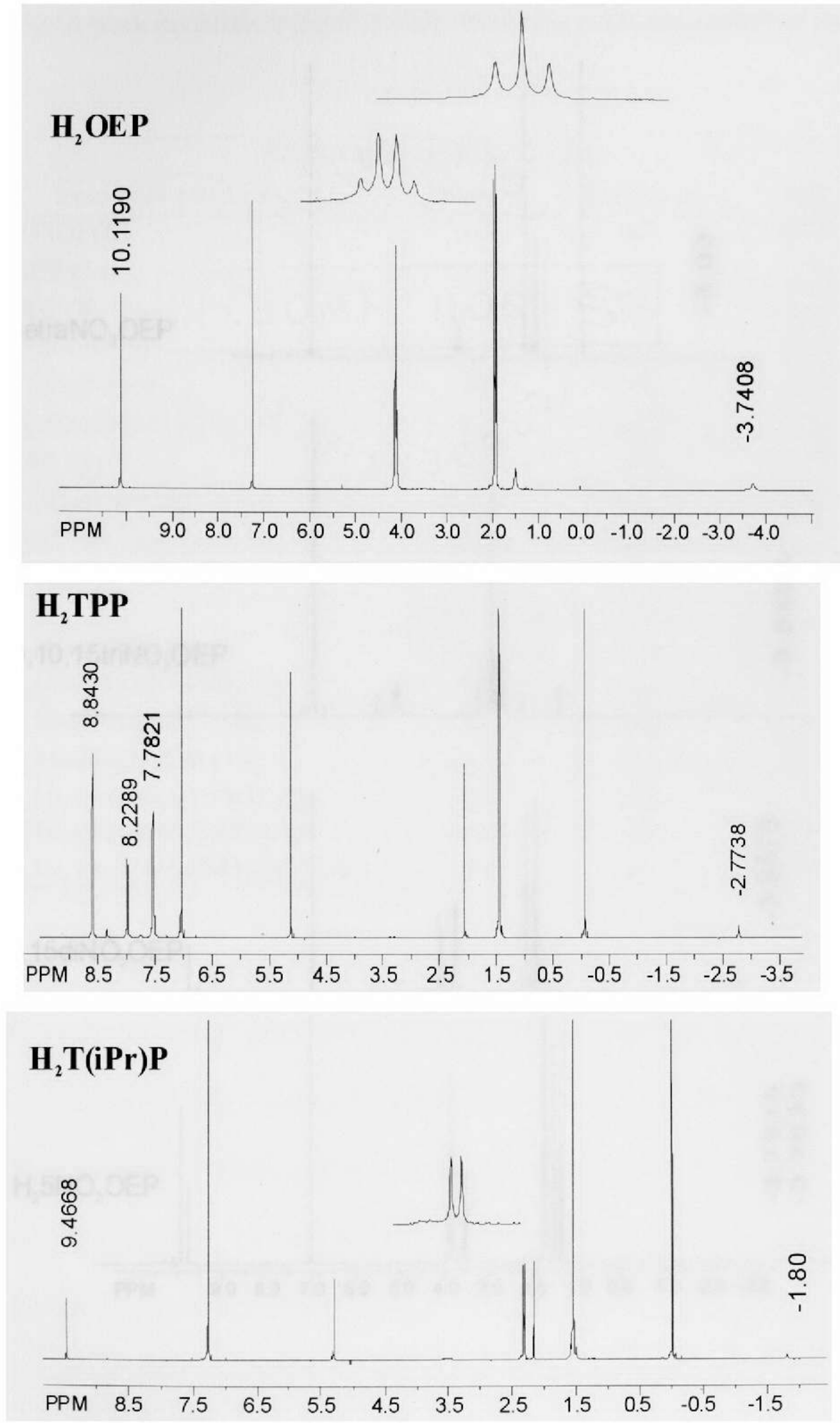

Figure 38. ${ }^{1} \mathrm{H}$ NMR spectra of $\mathrm{H}_{2} \mathrm{OEP}(5), \mathrm{H}_{2} \mathrm{TPP}(8)$, and $\mathrm{H}_{2} \mathrm{~T}(\mathrm{iPr}) \mathrm{P}(10)$. 

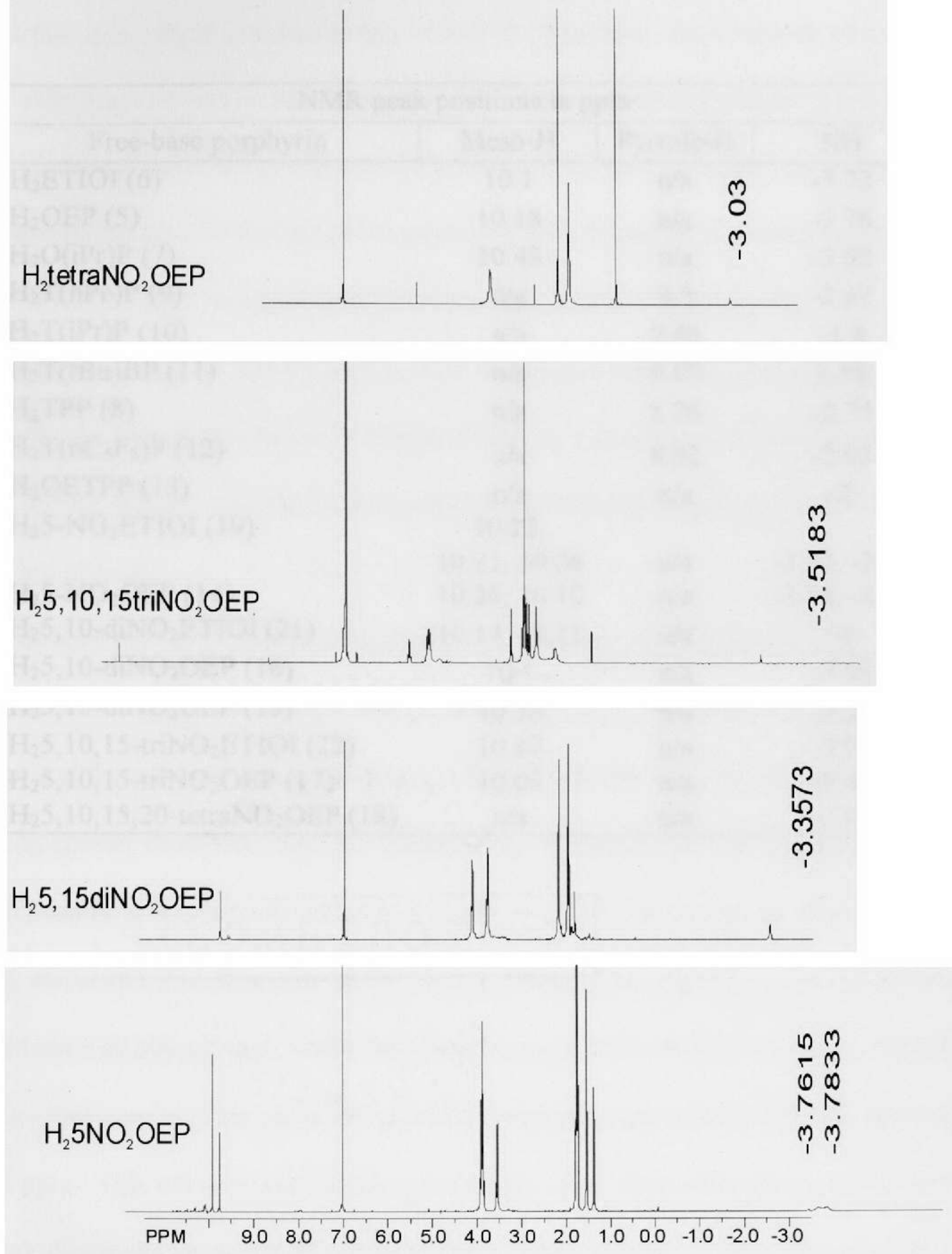

Figure 39. ${ }^{1} \mathrm{H}$ NMR spectra of the nitrated $\mathrm{H}_{2} \mathrm{OEP}(5)$. 
Table 29. NMR peak positions in ppm. (results from this work and published data)

\begin{tabular}{|c|c|c|c|}
\hline \multicolumn{4}{|c|}{ NMR peak positions in $\mathrm{ppm}$} \\
\hline Free-base porphyrin & Meso-H & Pyrrole-H & $\mathrm{NH}$ \\
\hline $\mathrm{H}_{2}$ ETIOI (6) & 10.1 & $\mathrm{n} / \mathrm{a}$ & -3.73 \\
\hline $\mathrm{H}_{2} \mathrm{OEP}(5)$ & 10.18 & $\mathrm{n} / \mathrm{a}$ & -3.76 \\
\hline $\mathrm{H}_{2} \mathrm{O}(\mathrm{iPr}) \mathrm{P}(7)$ & 10.48 & $\mathrm{n} / \mathrm{a}$ & -3.92 \\
\hline $\mathrm{H}_{2} \mathrm{~T}(\mathrm{nPe}) \mathrm{P}(9)$ & $\mathrm{n} / \mathrm{a}$ & 9.5 & -2.62 \\
\hline $\mathrm{H}_{2} \mathrm{~T}(\mathrm{iPr}) \mathrm{P}(10)$ & $\mathrm{n} / \mathrm{a}$ & 9.46 & -1.8 \\
\hline $\mathrm{H}_{2} \mathrm{~T}(\mathrm{tBu}) \mathrm{BP}(11)$ & $\mathrm{n} / \mathrm{a}$ & 9.07 & 1.58 \\
\hline $\mathrm{H}_{2} \mathrm{TPP}(8)$ & $\mathrm{n} / \mathrm{a}$ & 8.76 & -2.74 \\
\hline $\mathrm{H}_{2} \mathrm{~T}\left(\mathrm{nC}_{5} \mathrm{~F}_{5}\right) \mathrm{P}(12)$ & $\mathrm{n} / \mathrm{a}$ & 8.92 & -2.92 \\
\hline $\mathrm{H}_{2} \mathrm{OETPP}(13)$ & $\mathrm{n} / \mathrm{a}$ & $\mathrm{n} / \mathrm{a}$ & -2 \\
\hline $\mathrm{H}_{2} 5-\mathrm{NO}_{2}$ ETIOI (19) & 10.23 & & \\
\hline & $10.21,10.08$ & $\mathrm{n} / \mathrm{a}$ & $-3.72,-3.91$ \\
\hline $\mathrm{H}_{2} 5-\mathrm{NO}_{2} \mathrm{OEP}(14)$ & $10.25,10.10$ & $\mathrm{n} / \mathrm{a}$ & $-3.54,-3.77$ \\
\hline $\mathrm{H}_{2} 5,10$-diNO 2 ETIOI (21) & $10.13,10.11$ & $\mathrm{n} / \mathrm{a}$ & -4 \\
\hline $\mathrm{H}_{2} 5,10-$ diNO$_{2} \mathrm{OEP}(16)$ & 10.1 & $\mathrm{n} / \mathrm{a}$ & -3.95 \\
\hline $\mathrm{H}_{2} 5,15-\mathrm{diNO}_{2} \mathrm{OEP}(15)$ & 10.36 & $\mathrm{n} / \mathrm{a}$ & -3.36 \\
\hline $\mathrm{H}_{2} 5,10,15$-triNO ${ }_{2}$ ETIOI (22) & 10.17 & $\mathrm{n} / \mathrm{a}$ & -3.79 \\
\hline $\mathrm{H}_{2} 5,10,15-$ triNO $_{2} \mathrm{OEP}(17)$ & 10.09 & $\mathrm{n} / \mathrm{a}$ & -3.46 \\
\hline $\mathrm{H}_{2} 5,10,15,20$-tetraNO${ }_{2} \mathrm{OEP}(18)$ & $\mathrm{n} / \mathrm{a}$ & $\mathrm{n} / \mathrm{a}$ & -3.03 \\
\hline
\end{tabular}


In the series $\mathrm{H}_{2} \mathrm{ETIOI}(6) \sim \mathrm{H}_{2} \mathrm{OEP}(5)<\mathrm{H}_{2} \mathrm{O}(\mathrm{iPr}) \mathrm{P}(7)$, the position of the meso- $\mathrm{H}$ goes further down field with increasing size of the R groups. Assuming all of these are planar, this effect should be due to an increased electron donating ability of the isopropyl group. Indeed for the NH group, precisely the same effect is seen but in the opposite direction. It may also be that since the pyrrole $\mathrm{N} \mathrm{H-N}$ distances are closer for $\mathrm{H}_{2} \mathrm{OEP}$ (5) and $\mathrm{H}_{2}$ ETIOI (6) than for $\mathrm{H}_{2} \mathrm{O}(\mathrm{iPr}) \mathrm{P}$ (7), there may be less intramolecular hydrogen bonding taking place for this molecule. This would also push the N-H signal more upfield for $\mathrm{H}_{2} \mathrm{O}(\mathrm{iPr}) \mathrm{P}$ (7). In the N-H peak positions it is difficult to establish what is due to ring current effects, and what is due to hydrogen bonding effects, it is clear that both effects are present.

In the tetra aryl meso substituted porphyrins, the situation is more complicated. There are significant ring current effects emanating from both the aryl groups at the meso position and from the porphyrin macrocycle itself. Crystal structures and our own modeling studies show that there is a dihedral angle between each of the phenyl groups and the porphyrin macrocycle which is around $60^{\circ}$. This will situate the pyrrole protons directly above the shielding cone of the phenyl group. The porphyrin macrocycle will deshield the pyrrolic protons, while the phenyl groups at the meso position will shield the protons. This can be observed in the pyrrolic hydrogen signals for $\mathrm{H}_{2}$ TPP (8) appearing at $8.76 \mathrm{ppm}$. This value is smaller than that for the tetra alkyl substituted porphyrins (9$9.5 \mathrm{ppm}$ ), due to the shielding effects of the meso phenyl groups. When the meso-phenyl groups are replaced by pentafluorophenyl groups this shielding effect is reduced due to the electron withdrawing effects of the fluorines. Also, since the pentafluorophenyl groups are electron withdrawing resulting in a reduced ring current in the macrocycle. 
These two effects should counter each other but since the pentafluorophenyl groups are at a $60^{\circ}$ angle, to the macrocycle, the effect on the macrocyclic ring current is not as pronounced since the mechanism is limited to inductive and resonance is not possible between perpendicular $\pi$-systems. The pyrrolic hydrogens appear at $8.92 \mathrm{ppm}$. In the $\mathrm{N}-\mathrm{H}$ region, the protons for $\mathrm{H}_{2} \mathrm{TPP}$ appear at $-2.74 \mathrm{ppm}$. When the pentafluorophenyl groups replace the phenyl groups, the N-H signal shift slightly upfield. We believe this is due to reduced ring current on the macrocycle due to the electron withdrawing ability of the pentafluorophenyl group.

In the tetraalkylsubstituted porphyrins, NMR shifts have more to do with the macrocyclic conformation and the capacity for intramolecular hydrogen bonding. In the series $\mathrm{H}_{2} \mathrm{~T}(\mathrm{nPe}) \mathrm{P}(9) ; \mathrm{H}_{2} \mathrm{~T}(\mathrm{iPr}) \mathrm{P}(10)$ and $\mathrm{H}_{2} \mathrm{~T}(\mathrm{tBu}) \mathrm{P}(11)$, the degree of ruffling increases, as shown by the increase in the opposing pyrrole torsion angle from $0.12^{\circ}$ to $21^{\circ}$ to $47^{\circ}$. The pyrrole $\mathrm{H}$ signals shift slightly upfield, as the degree of ruffling increases. Some of this effect may be due to a slightly larger electron donating effect due to the alkyl groups but also as the molecule becomes more ruffled the ring current is reduced thereby causing the pyrrole hydrogens to appear more upfield.

For the N-H protons the shift is exactly the opposite, since the $\mathrm{N}-\mathrm{H}$ protons are in the shielding region. The larger the degree of ruffling the weaker the ring current. This will reduce the amount of shielding and this is observed in the $\mathrm{N}-\mathrm{H}$ protons appearing further downfield with increasing ruffling $\mathrm{H}_{2} \mathrm{~T}(\mathrm{nPe}) \mathrm{P}\left(-2.62 \mathrm{ppm}\right.$ ) followed by $\mathrm{H}_{2} \mathrm{~T}(\mathrm{iPr}) \mathrm{P}(-1.8)$ followed by $\mathrm{H}_{2} \mathrm{~T}(\mathrm{tBu}) \mathrm{P}(+1.58)$. The influence of geometry on the $\mathrm{NH}$ groups seems to be much greater than that observed for the pyrrole- $\mathrm{H}$ signals. Medforth et al have 
postulated that a much greater effect is observed due to the ability of the ruffled macrocycles to hydrogen bond than the planar or saddled macrocycles. [31] A number of complexes display fluxional behavior in ${ }^{1} \mathrm{H}$ NMR. One of the reasons for this fluxional behavior is the ability of the porphyrin to tautomerize as shown in Figure 1(b) and 7. If the tautomerization occurs at a rate that is fast on the ${ }^{1} \mathrm{H}$ NMR time scale, an average of the peaks is observed. If it occurs at a rate which is slow on the ${ }^{1} \mathrm{H}$ NMR time scale then separate and distinct peaks may seen. Although this tautomerization occurs for all porphyrins, it has been observed only when it results in hydrogens occupying environments which are magnetically distinct enough so they may be observed at an accessible temperature. When variable temperature ${ }^{1} \mathrm{H}$ NMR studies can be carried out the free energy of activation $\left(\Delta G^{*}\right)$ for tautomerization can be determined using the equation shown below as described in reference [30].

$$
\begin{aligned}
\Delta \mathrm{G}^{*} & =\operatorname{RTc}\left\{(\sqrt{ } 2 \mathrm{R} / \pi \mathrm{Nh})+\ln \left(\mathrm{Tc} / \delta_{\mathrm{v}}\right)\right\} \\
\Delta \mathrm{G}^{*} & =\operatorname{RTc}\left\{22.96+\ln \left(\operatorname{Tc} / \delta_{\mathrm{v}}\right)\right\}
\end{aligned}
$$

Such behavior was found for four of the porphyrins studied. In Figures 35 to 38 are the variable temperature spectra of these four porphyrins. The $\Delta \mathrm{G}^{*}$, along with the $\Delta \mathrm{G}^{*}$ for other free-base porphyrins which have been published are presented. Both the $\mathrm{H}_{2} 5$ $\mathrm{NO}_{2}$-OEP (14) and $\mathrm{H}_{2} 5-\mathrm{NO}_{2}$ ETIOI (19) show fluxional behavior. The $\Delta \mathrm{G}^{*}$ for the tautomerization is $15.22 \mathrm{kcal} / \mathrm{mole}$ and $15.04 \mathrm{kcal} / \mathrm{mole}$. These values were surprisingly high particularly when compared to that of $\mathrm{H}_{2} \mathrm{OETPP}$ (13) which is $13.6 \mathrm{kcal} / \mathrm{mole}$. Additionally the fluxional behavior of $\mathrm{H}_{2} 5,10,15-\mathrm{NO}_{2} \mathrm{OEP}$ (18) was also studied. The 
$\Delta \mathrm{G}^{*}$ calculated was $+10.4 \mathrm{kcal} / \mathrm{mole}$. This also seemed unusual since that for $\mathrm{H}_{2} \mathrm{TPP}(8)$ is around 12 and that is a planar molecule.

In the $\mathrm{H}_{2} 5,10,15-\mathrm{NO}_{2} \mathrm{OEP}(17)$, the peaks which are fluxional is those of the ethyl group. Depending on whether the pyrrole is protonated, the peaks will appear in different places. As the temperature is raised from $243 \mathrm{~K}$ to $278 \mathrm{~K}$ the peaks coalesce. The distance between the two adjacent nitrogens is $2.84 \AA$. This is the distance the $\mathrm{H}$ has to bridge in order to form the transition state for tautomerization. In the $\mathrm{H}_{2} 5-\mathrm{NO}_{2} \mathrm{OEP}$ (14) and $\mathrm{H}_{2} 5-\mathrm{NO}_{2}$ ETIOI (19), the groups which show the fluxional behavior are the $\mathrm{N}-\mathrm{H}$ group themselves (in addition to fluxionality in the ethyl groups). In transferring the proton from $\mathrm{N}_{21}$ to $\mathrm{N}_{22}$ simultaneously with $\mathrm{N}_{23}-\mathrm{N}_{24}$ no change in the $\mathrm{NH}$ proton signal is observed. As is shown in Figure 35 this is the short $\mathrm{NN}$ distance $\mathrm{D}_{\mathrm{y}}$ since this molecule has an in plane distortion which makes $D_{y}$ and $D_{z}$ different. The only exchange that will make the NH signals appear in different places and coalesce is $N_{24}$ to $N_{21}$ and $N_{23}$ to $N_{22}$. These are the long NN distances $D_{z}$. This bond distance is $2.9 \AA$, larger than the others. In the $\mathrm{H}_{2} 5,10,15$-triNO${ }_{2} \mathrm{OEP}$ (17), the opposite is observed. The only proton transfer which will cause fluxional behavior is that between the $N_{21}$ to $N_{22}$ and $N_{23}$ to $N_{24}$. This is the short N-N distance, $\mathrm{D}_{\mathrm{y}}$, which is $2.74 \AA$. For the $\mathrm{NO}_{2}$ substituted compounds, the $\Delta \mathrm{G}^{*}$ to correlates well with the $\mathrm{NN}$ bond distances. 


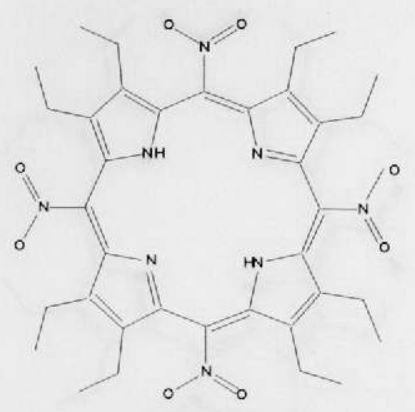

$\mathrm{H}_{2}$ tetraNO $\mathrm{NEP}_{2}$

$273 \mathrm{~K}$

$270 \mathrm{~K}$

$268 \mathrm{~K}$

$263 \mathrm{~K}$

$253 \mathrm{~K}$

$243 \mathrm{~K}$

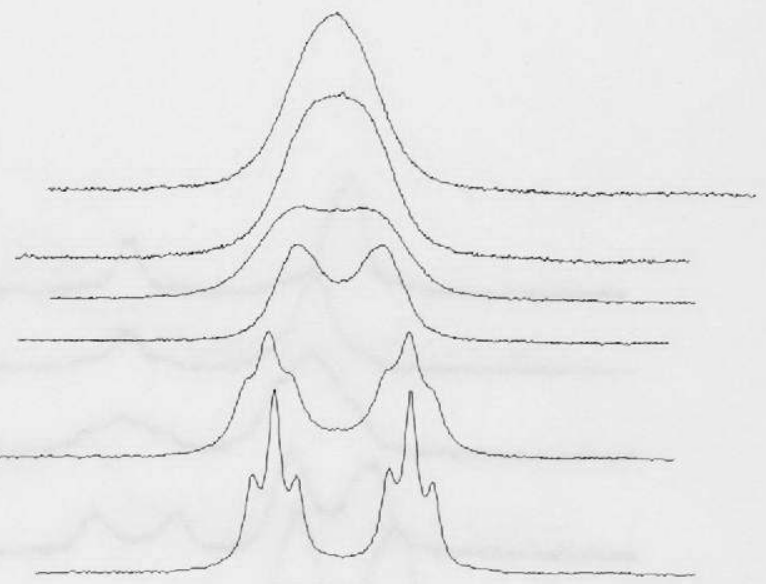

$\begin{array}{llllllllllllll}\text { PPM } & 1.40 & 1.36 & 1.32 & 1.28 & 1.24 & 1.20 & 1.16 & 1.12 & 1.08 & 1.04 & 1.00 & 0.96\end{array}$

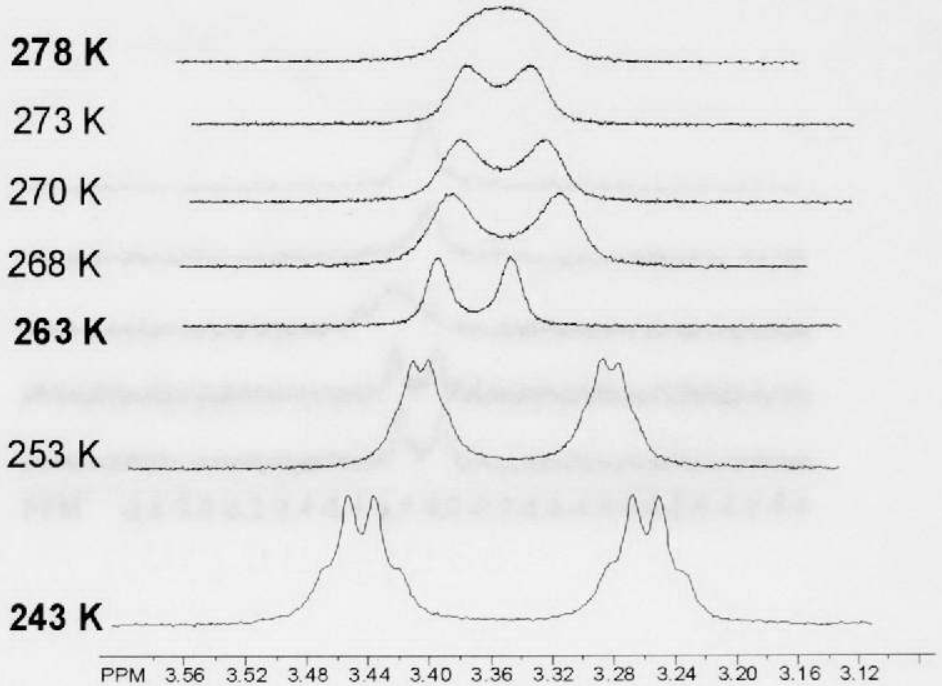

Figure 40. Variable temperature spectra of $\mathrm{H}_{2} 5,10,15,20-\mathrm{NO}_{2} \mathrm{OEP}$ (18), (a) $-\mathrm{CH}_{3}$ region and (b) $-\mathrm{CH}_{2}$ - region. 


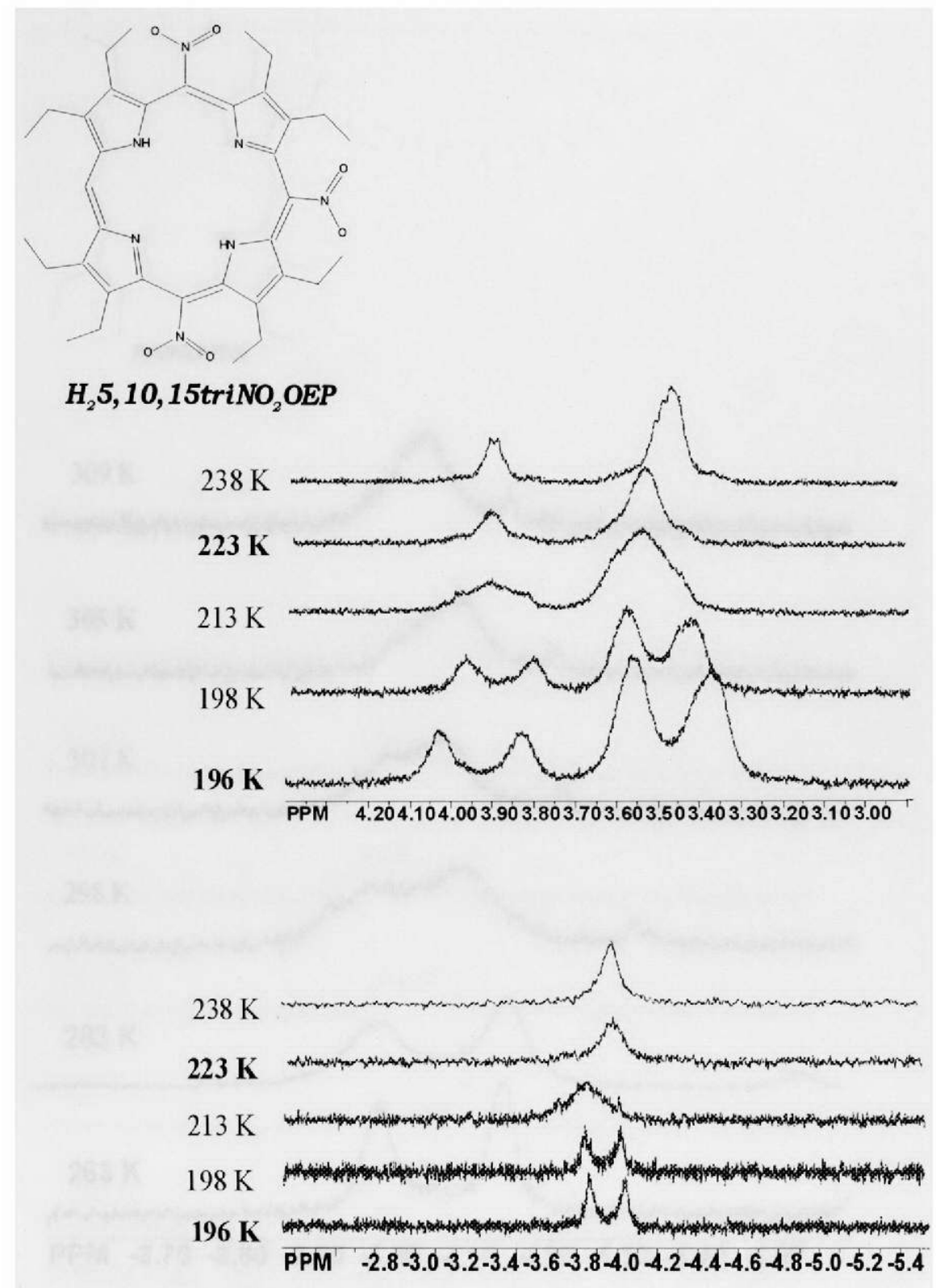

Figure 41. Variable temperature spectra of $\mathrm{H}_{2} 5,10,15-\mathrm{NO}_{2} \mathrm{OEP}$ (17). 

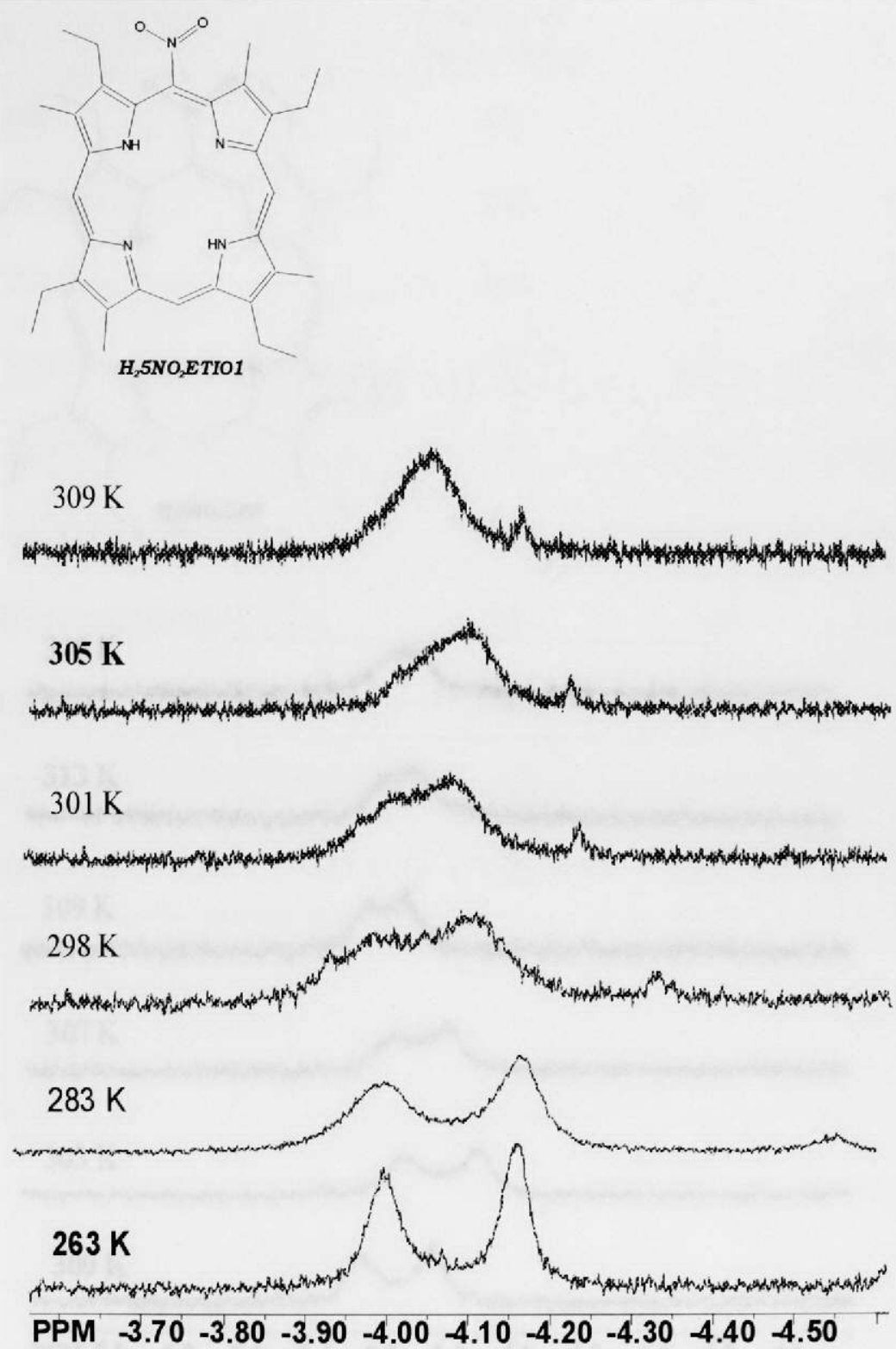

Figure 42. Variable temperature spectra of $\mathrm{H}_{2} 5-\mathrm{NO}_{2}$ ETIOI (19). 


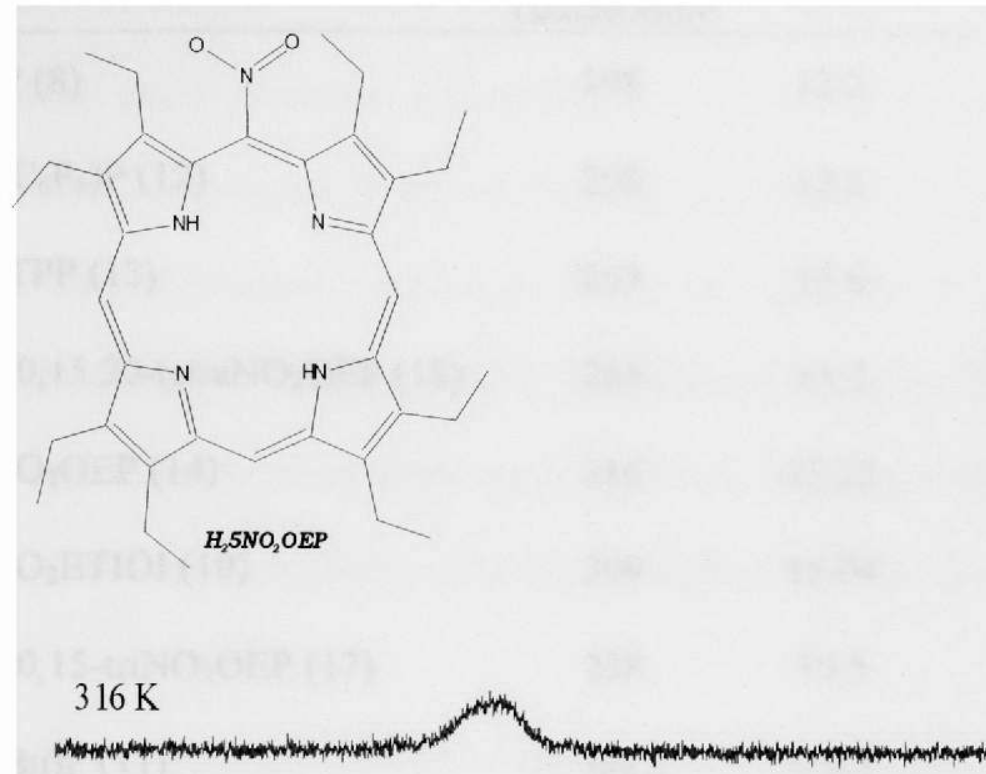

\section{$313 \mathrm{~K}$}

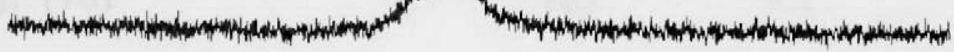

$309 \mathrm{~K}$
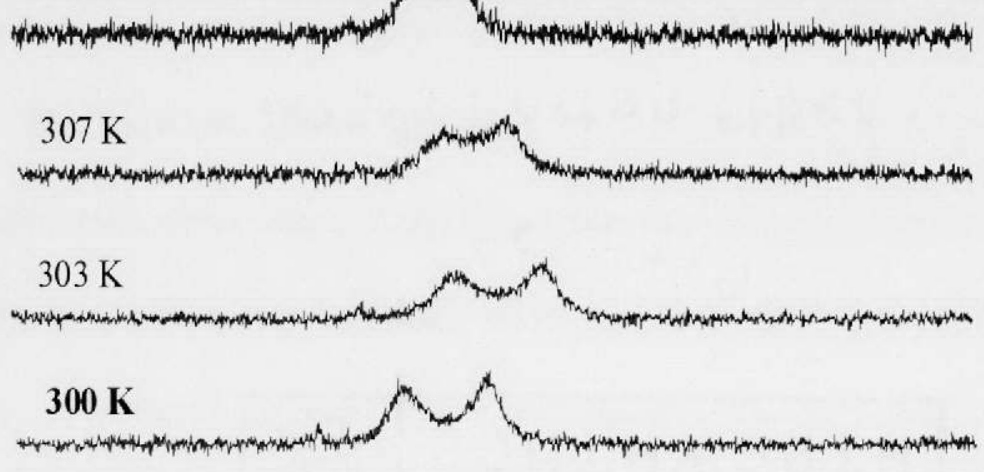

\begin{tabular}{lllllllllllll}
\hline PPM-2.8 & -3.0 & -3.2 & -3.4 & -3.6 & -3.8 & -4.0 & -4.2 & -4.4 & -4.6 & -4.8
\end{tabular}

Figure 43. Variable temperature spectra of $\mathrm{H}_{2} 5-\mathrm{NO}_{2} \mathrm{OEP}$ (14). 
Table $30 . \Delta \mathrm{G}^{*}$ for the tautomerization of different free-base porphyrins.

\begin{tabular}{|c|c|c|c|}
\hline free-base & $\begin{array}{l}\text { Coalescence } \\
\text { Temperature }\end{array}$ & $\Delta \mathrm{G}^{*}$ & Reference \\
\hline $\mathrm{H}_{2} \mathrm{TPP}(8)$ & 298 & 12.2 & [81] \\
\hline $\mathrm{H}_{2} \mathrm{~T}\left(\mathrm{nC}_{6} \mathrm{~F}_{5}\right) \mathrm{P}(12)$ & 298 & 12.2 & [82] \\
\hline $\mathrm{H}_{2} \mathrm{OETPP}(13)$ & 293 & 13.6 & [83] \\
\hline $\mathrm{H}_{2}-5,10,15,20$-tetraNO${ }_{2} \mathrm{OEP}(18)$ & 263 & 13.2 & $\begin{array}{c}\text { this work and } \\
{[84]}\end{array}$ \\
\hline $\mathrm{H}_{2}-5 \mathrm{NO}_{2} \mathrm{OEP}(14)$ & 316 & 15.22 & this work \\
\hline $\mathrm{H}_{2}-5 \mathrm{NO}_{2}$ ETIOI (19) & 309 & 15.04 & this work \\
\hline $\mathrm{H}_{2}-5,10,15$-triNO ${ }_{2} \mathrm{OEP}(17)$ & 238 & 10.5 & this work \\
\hline $\mathrm{H}_{2} \mathrm{~T}(\mathrm{tBu}) \mathrm{P}(11)$ & $\mathrm{n} / \mathrm{a}$ & $<9.1$ & [31] \\
\hline $\mathrm{H}_{2} \mathrm{~T}(\mathrm{iPr}) \mathrm{P}(10)$ & 183 & 9.1 & {$[31]$} \\
\hline $\mathrm{H}_{2} \mathrm{~T}(\mathrm{nPe}) \mathrm{P}(9)$ & 238 & 12.0 & [31] \\
\hline
\end{tabular}




\section{Conclusions}

\subsection{Calorimetry studies.}

Porphyrin macrocycle distortion was found to affect: the enthalpy of solution and the relative basicity of the porphyrin. The enthalpies of solution of the free-base porphyrins in 1, 1,2, 2 tetrachloroethane decrease with increasing macrocyclic distortion. The relative basicities of porphyrins increases when groups of similar electron withdrawing abilities on the periphery increase in steric size. When the electron withdrawing groups are introduced on the periphery of the macrocycle, the relative basicity of the free-base porphyrins decreases substantially and can overwhelm the effects due to macrocyclic distortion.

The basicity of octaalkyl substituted porphyrins decreased as the steric size of the alkyl group increase. This may be due to stability differences in their respective dications and their final saddle structure. In tetraalkylsubstituted porphyrins, the identity of the meso group does not seem to influence the basicity until the bulky t-butyl group is introduced. There are two effects occurring; the bulkier alkyl group leads to greater ruffling macrocyclic distortion and the larger the alkyl group, the more intramolecular hydrogen bonding which may be taking place. For $\mathrm{H}_{2} \mathrm{~T}(\mathrm{iPr}) \mathrm{P}$ these effects seem to be canceling out. For the $\mathrm{H}_{2} \mathrm{~T}(\mathrm{tBu}) \mathrm{P}$ they do not and the basicity increases accordingly.

In dodecasubstituted porphyrins with no electron withdrawing groups, the macrocyclic distortion is so great that there is an increase in the basicity of the free base porphyrin by $26 \mathrm{kcal} / \mathrm{mole}$.

When adding electron withdrawing groups the decrease in basicity is dramatic. Using a combination of electronic effects and macrocyclic distortion the relative basicity 
of a free base porphyrin can be manipulated such that there is an enthalpy of two proton transfer between two different porphyrins of close to $45 \mathrm{kcal} / \mathrm{mole}$.

$$
\begin{gathered}
\mathrm{H}_{4} \mathrm{~T}\left(\mathrm{C}_{6} \mathrm{~F}_{5}\right) \mathrm{P}^{+2}+\mathrm{H}_{2} \mathrm{OEP} \rightarrow \mathrm{H}_{2} \mathrm{~T}\left(\mathrm{C}_{6} \mathrm{~F}_{5}\right) \mathrm{P}+\mathrm{H}_{4} \mathrm{OEP}^{+2} \\
\Delta \mathrm{H}_{\text {proton trans }}=-45 \mathrm{kcal} / \mathrm{mole}
\end{gathered}
$$

\subsection{Molecular modeling.}

The best predictor of the free-base porphyrin structure was molecular mechanics as was expected. The best predictor of free-base porphyrin basicity were both B3LYP/6$31 \mathrm{G}^{*} / / \mathrm{MM}+$ and $\mathrm{PM} 3 \mathrm{RHF} / \mathrm{MM}+$.

\section{$7.3{ }^{1} \mathrm{H}$ NMR.}

In the tautomerization of the free-base porphyrin, the closer the nitrogens are, the lower the $\Delta \mathrm{G}^{\ddagger}$ of tautomerization. This indicates a greater degree of intramolecular hydrogen bonding for these porphyrins. 


\section{References}

1. Smith, K., General features of the structure and chemistry of porphyrin compounds, in Porphyrins and Metalloporphyrins, K. Smith, Editor. 1975, Elsevier Scientific: New York. p. 1-27.

2. Daley, H.A., Biosynthesis of Heme and Chlorophylls, ed. I. McGrawHill. 1990, New York.

3. James, L.K., Nobel Laureates in Chemistry, in American Chemical Society. 1993: Washington, DC.

4. Fischer, H. and H. Orth, Die Chimie des Pyrrols. Vol. I. 1937a, Leipzig: Akademische Verlagsgesellschaft.

5. Fischer, H. and H. Orth, Die Chimie des Pyrrols. Vol. II(i). 1937b, Leipzig: Akademische Verlagsgesellschaft.

6. Fischer, H. and H. Orth, Die Chimie des Pyrrols. Vol. II(ii). 1940, Leipzig: Akademische Verlagsgesellschaft.

7. Deisenhofer, J. and H. Michel, Science, 1989. 245: p. 1463-1473.

8. Lippard, S.J. and J.M. Berg, Principles of Bioinoganic Chemistry. 1994, Mills Valley, CA: University Science Books.

9. Blum, H.F., Photodynamic Action and Diseases Caused by Light, ed. V. Nostrand-Reinhold. 1941, Princeton, NJ.

10. Downey, D., Med. Hypotheses. Vol. 46. 1996. 378-382.

11. Mercer-Smith, J.A. and D.C. Mauzerall, Photochemistry of porphyrins: a model for the origin of photosynthesis. Photochem. Photobiol., 1984. 39(3): p. 397-405.

12. Ferrand, Y., P. Le Maux, and G. Simmoneaux, Highly enantioselective synthesis of cyclopropylphosphonates catalyzed by chiral ruthenium porphyrins. Organic Letters, 2004. 6(18): p. 3211-3214.

13. Wang, Z., C.J. Medforth, and J.A. Shelnutt, Porphyrin Nanotubes by Ionic SelfAssembly. Journal of the American Chemical Society, 2004. 126(49): p. 1595415955.

14. Wang, Z., C.J. Medforth, and J.A. Shelnutt, Self-Metallization of Photocatalytic Porphyrin Nanotubes. Journal of the American Chemical Society, 2004. 126(51): p. $16720-16721$. 
15. Treibs, A., Organic minerals. III. Chlorophyll and hemin derivatives in bituminous rocks, petroleums, mineral waxes and asphalts. Origin of petroleum. Ann., 1934. 510: p. 42-62.

16. Treibs, A., Chlorophyll and hemin derivatives in organic mineral substances. Angew. Chem., 1936. 49: p. 682-686.

17. Smith, K., Strategies for the synthesis of octaalkylporphyrin systems., in The Porphyrin Handbook, K.M. Kadish, K.M. Smith, and E. R. Guilar, Editors. 2000, Academic Press: San Diego, California. p. 1-43.

18. Smith, K.M., Porphyrins, Corrins and Phthalocyanines In: Comprehensive Heterocyclic Chemistry-Structure, Reactions, Synthesis and uses of Heterocyclic Compounds., ed. A.R.K.a.C.W. Rees. Vol. 4. 1984: Pergamon. 377-442.

19. Rothemund, P.J., Journal of the American Chemical Society, 1935. 57: p. 2010.

20. Adler, A.D., et al., A simplified synthesis for meso-tetraphenylporphine. Journal of Organic Chemistry, 1967. 32: p. 476.

21. Adler, A.D., et al., Mechanistic study of the synthesis of meso-tetraphenylporphin. Heterocyclic Chemistry, 1968. 5: p. 669.

22. Lindsey, J.S., et al., Rothemund and Adler-Longo reactions revisited: synthesis of tetraphenylporphyrins under equilibrium conditions. Journal of Organic Chemistry, 1987. 52(5): p. 827-836.

23. Gouterman, M., Optical Spectra and Electronic Structure of Porphyrins and Related Rings, in The Porphyrins, D. Dolphin, Editor. 1978, Academic Press. p. $1-163$.

24. Scheer, H. and J. Katz, Nuclear magnetic resonance spectroscopy of porphyrins and metalloporphyrins., in Porphyrins and Metalloporphyrins, K.M. Smith, Editor. 1975, Elsevier: Amsterdam, Netherlands.

25. Jason, T.R. and J.J. Katz, Nuclear magnetic resonance spectroscopy of diamagnetic porphyrins., in Porphyrins, D. Dolphin, Editor. 1979, Academic Press: New York, NY. p. 1-59.

26. Medforth, C.J., NMR Spectroscopy of Diamagnetic Porphyrins, in The Porphyrin Handbook, K.M. Kadish, R. Guilard, and K.M. Smith, Editors. 2000, Academic Press: San Diego, CA. p. 1.

27. Medforth, C.J.M., Cinzia M.; Shea, Kalyn M.; Smith, Kevin M.; Abraham, Raymond J.; Jia, Songling; Shelnutt, John A., NMR studies of nonplanar 
porphyrins. Part 2. Effect of nonplanar conformational distortions on the porphyrin ring current. Journal of the Chemical Society, Perkin Transactions 2: Physical Organic Chemistry, 1997. 4: p. 839-844.

28. Abraham, R.J., et al., The Nuclear Magnetic Resonance Spectra of Porphyrins XI. Tetrahedron, 1976. 32: p. 2949-2956.

29. Abraham, R.J., B. Evans, and K.M. Smith, The NMR Spectra of Porphyrins-14. Tetrahedron, 1978. 34: p. 1213-1220.

30. Abraham, R.J., J. Fisher, and P. Loftus, Introduction to NMR, ed. J.W.S. Ltd. 1988: Redwood Books Trowbridge, Wiltshire.

31. Somma, M.S., et al., Evidence for unusually strong intramolecular hydrogen bonding in highly nonplanar porphyrins. Chemical Communications, 1999. 13: p. 1221-1223.

32. Storm, C.B. and Y. Teklu, Nitrogen -hydrogen tautomerism in porphyrins and chlorines. Journal of the American Chemical Society, 1972. 94(5): p. 1745.

33. Abraham, R.J. and e. al., Nuclear magnetic resonance spectra of porphyrins $X$. Carbon-13 nuclear magnetic resonance spectra of meso-tetraarylporphyrins and their metal chelates. Journal of the Chemical Society, Perkin Transactions 2: Physical Organic Chemistry (1972-1999), 1975. 3: p. 204.

34. Abraham, R.J., G.E. Hawkes, and K.M. Smith, Nitrogen-hydrogen tautomerism in porphyrins. NMR study. Tetrahedron Letters, 1974. 16: p. 1483.

35. Eaton, S.S. and G.R. Eaton, Kinetic isotope effect on proton tautomerism in tetraarylporphyrins. Journal of the American Chemical Society, 1977. 99: p. 1601.

36. Piekarski, H., Calorimetry - An Important tool in solution chemistry. Thermochimica Acta, 2004. 420(1-2): p. 13-18.

37. Clavet, E., Compensated differential microcalorimeter. Compt. Rend, 1948. 1948(226): p. 1702-1704.

38. Berezin, D.B., et al., Solvation and molecular distortion effects in the thermochemistry of protonation of tetraphenylporphine derivatives. Russian Journal of General Chemistry, 2000. 70(9): p. 1453-1457.

39. Chernova, O.M. and M.B. Berezin, Thermochemistry of solution of porphyrins of the proto group in mixed organic solvents. Russian Journal of General Chemistry, 2000. 70(9): p. 1448-1552. 
40. Chernova, O.M. and M.B. Berezin, Thermochemistry of solution of natural porphyrins in benzene-electron donor mixed solvents. Zhurnal Fizicheskoi Khimii, 2000. 74(2): p. 199-202.

41. Wu, D., et al., Standard enthalpies of combustion and formation of porphyrin derivatives. Thermochimica Acta, 1989. 154(2): p. 233-245.

42. Jian-Guo Ma, M.L., Xing-Zhi Song, Walter Jentzen, Song-Ling Jia, Jun Zhang, Jane M. Vanderkooi, and John A. Shelnutt., Protein-Induced Changes in Nonplanarity of the Porphyrin in Nickel Cytochrome c Probed by Resonance Raman Spectroscopy. Biochemistry, 1998. 37: p. 5118-5128.

43. Shelnutt, J.A., et al., Nonplanar porphyrins and their significance in proteins. Chem. Soc. Rev., 1998. 27: p. 31-41.

44. John A. Shelnutt, X.-Z.S., Jian-Guo Ma, Song-Ling Jia, Walter Jentzen and Craig J. Medforth, Nonplanar porphyrins and their significance in proteins. Chem. Soc. Rev., 1998. 27: p. 31-41.

45. Ricardo Franco, J.-G.M., Yi Lu, Gloria C. Ferreira, and John A. Shelnutt, Porphyrin Interactions with Wild-type and Mutant Mouse Ferrochelatase. Biochemistry, 2000. 39: p. 2517-2529.

46. Thomas G. Spiro, G.S., and Chang Su, Probing Protein Structure and Dynamics with Resonance Raman Spectroscopy: Cytohcrome c Peroxidase and Hemoglobin. Biochemistry, 1990. 29(19): p. 4497-4508.

47. Shelnutt, J.A., Molecular Simulations and Normal-Coordinate Analysis of Porphyrins and Heme Proteins, in The Porphyrin Handbook, K.M. Kadish, K.M. Smith, and R. Guilard, Editors. 2000, Academic Press: New York, NY.

48. Shelnutt, J.A.S., X.-Z.; Ma, J.-G., Jentzen, W., Medforth, C. J., Nonplanar porphyrins and their significance in proteins. Chem. Soc. Rev., 1998. 31.

49. Williams, R.J., The Entatic State. Cold Spring Harbor symposia on quantitative biology, 1972. 32: p. 53-62.

50. Vallee, B.L. and R.J. Williams, Metalloenzymes: the entatic nature of their active sites. Proceedings of the National Academy of Sciences of the United States of America, 1968. 59(2): p. 498-505.

51. Senge, M.O., Highly Substituted Porphyrins, in The Porphyrin Handbook, K.M Kadish, R. Guilard, and K.M. Smith, Editors. 2000, Academic Press: San Diego, Ca. p. 239-347. 
52. Scheidt, W.R., Systematics of the Stereochemistry of Porphyrins and Metalloporphyrins, in The Porphyrin Handbook, K.M.S. K.M. Kadish, R. Guilar, Eds, Editor. 2000, Academic Press: San Diego, CA.

53. Cullen, D.L.M.J., E. F.; Smith K. M., Inorganic Chemistry, 1977. 16: p. 1179.

54. Sparks, L.D., et al., Metal dependence of the nonplanar distortion of octaalkyltetraphenylporphyrins. Journal of the American Chemical Society, 1993. 115: p. 581-592.

55. Hoard, J.L., M.J. Hamor, and T.A. Hamor, Configuration of the porphine skeleton in unconstrained porphyrin molecules. Journal of the American Chemical Society, 1963. 85(15): p. 2334-2335.

56. Hamor, M.J., T.A. Hamor, and J.L. Hoard, The structure of crystalline tetraphenylporphine. The stereochemical nature of the porphine skeleton. Journal of the American Chemical Society, 1964. 86(10): p. 1938-1942.

57. Silvers, S.J. and A. Tulinsky, The Crystal and Molecular Structure of Triclinic Tetraphenylporphyrin. Journal of the American Chemical Society, 1967. 89:13: p. 3331-3337.

58. Lauher, J.W. and J.A. Ibers, Structure of Octaethylporphyrin. A Comparison with Other Free Base Porphyrins. Journal of the American Chemical Society, 1973. 95:16: p. 5148-5152.

59. Senge, M., Database of tetrapyrrole crystal structure determinations, in The Porphyrin Handbook, K.M. Kadish, K.M. Smith, and R. Guilard, Editors. 2000, Academic Press: San Diego.

60. Leach, A.R., Molecular Modeling. Principles and Applications. 1996: Pearson Education Limited, Harlow Essex, England. 595.

61. Cramer, C.J., Essentials of Computational Chemistry. Theories and Models. 2002 John Wiley \& Sons Ltd, West Sussex, England. 542.

62. Rappe, A.K. and C.J. Casewit, Molecular Mechanics across Chemistry. 1997 : University Science Books, Sausalito, CA. 444.

63. Bonnett, R., et al., Reactions of nitrous acid and nitric oxide with porphyrins and hemes. Nitrosylhemes as nitrosating agents. Journal of the Chemical Society, Chemical Communications, 1975, 21 : p. 884-885. 
64. Bonnett, R. and G.F. Stephenson, Meso-reactivity of porphyrins and related compounds. I. Nitration. Journal of Organic Chemistry, 1965. 30(8): p. 27912798 .

65. Gong, L.-C. and D. Dolphin, Nitrooctaethylporphyrins: synthesis, optical and redox properties. Canadian Journal of Chemistry, 1985. 63: p. 401-405.

66. Senge, M., et al., Synthesis, reactivity and structural chemistry of 5, 10,15,20tetraalkylporphyrins. Journal of Porphyrins and Phthalocyanines, 1999. 3: p. 99116.

67. Mamardashvili, G.M., N.Z. Mamardashvili, and B.D. Berezin, Molecules, 2000. 5: p. 762.

68. Mamardashvili, G.M., et al., Journal of Molecular Liquids, 2001. 91: p. 189.

69. Stone, A. and E.B. Fleischer, Journal of the American Chemical Society, 1968. 90: p. 2735.

70. Fleischer, E.B., Accounts of Chemical Research, 1970. 3: p. 105.

71. Senge, M.O. and W.W. Kalisch, Zeitschrift fuer Naturforschung, B: Chemical Sciences, 2004. 54: p. 943.

72. Cheng, B., et al., Journal of the American Chemical Society, 1997. 119: p. 10732.

73. Medforth, C.J., et al., Inorganic Chemistry, 2003. 42: p. 2227.

74. Chen, D.-M., et al., Density functional theory investigation of porphyrin diacid: electronic absorption spectrum and conformational inversion. Chemical Physics, 2003. 289: p. 397-407.

75. Cheng, B., et al., An analysis of Porphyrin Molecular Flexibility - Use of Porphyrin Diacids. Journal of the American Chemical Society, 1997. 119: $\mathrm{p}$. 10732-10742.

76. Stone, A. and E.B. Feischer, The molecular and crystal structure of porphyrin diacids. Journal of the American Chemical Society, 1968. 90: p. 2735.

77. Juillard, S., et al., Molecular structure of simple mono- and diphenyl mesosubstituted porphyrin diacids: influence of protonation and substitution on the distortion. Tetrahedron, 2005. 61: p. 3489-3495.

78. Dirks, J.W., et al., Conformational dynamics of $a, b, g, d$-tetraarylporphyrins and their dications. Journal of Organic Chemistry, 1979. 44(14): p. 2551-5. 
79. Senge, M.O. and W.W. Kalisch, Structure and Conformation of Tetra-meso-, Octa- $\beta$, and Dodecasubstituted 22,24-Dihydroporphyrins (Porphyrin Dications). Z. Naturforsch, 1999. 54b: p. 943-959.

80. Chirvony, V.S., et al., Comparative Study of the Photophysical Properties of Nonplanar Tetraphenylporphyrin and Octaethylporphyrin Diacids. Journal of physical Chemistry B, 2000. 104: p. 9909-9917.

81. Abraham, R.J., G.E. Hawkes, and K.M. Smith, Tetrahedron Letters, 1974. 16: p. 1483 .

82. Eaton, S.S. and G.R. Eaton, Journal of the American Chemical Society, 1977. 99 p. 1601 .

83. Barkigia, K.M., et al., Nonplanar Porphyrins. X-ray Structures of (2, 3, 7, 8, 12, 13, 17, 18-Octaethyl-and-Octamethyl -5, 10,15, 20 - tetraphenylporphinato) zinc (II). Journal of the American Chemical Society, 1990. 112: p. 8851-8857.

84. Hobbs, J.D., et al., Structural Heterogeneity and Coordination Chemistry of Nickel (II) Octaethyl-meso-nitroporphyrins. Journal of the American Chemical Society, 1994. 116: p. 3261-3270. 


\section{VITA}

MARIA BALLESTER

January 19, 1969

Born, Havana, Cuba

1998

B.S., Chemistry

Florida International University

Miami, Florida

$1998-2005$

Teaching Assistant

Florida International University

Miami, Florida

\section{SCIENTIFIC PUBLICATIONS AND PRESENTATIONS}

"Enthalpies of solution, proton exchange, and metal exchange of porphyrins and metalloporphyrins: Discussion of conformational and electronic considerations." R.Lopez de la Vega, J. M. E. Quirke, M. Ballester, N.B. Mintz. ACS Meeting in New Orleans, Spring 2003.

"Interlaboratory studies on multiplexed mtDNA HVI \& II and Y chromosome SNP kits using an automated liquid bead array system." et al ${ }^{20}$ Biloxi MS Promega October 2001. 